\title{
ipen
}

INSTITUTO DE PESQUISAS ENERGÉTICAS E NUCLEARES

Autarquia associada à Universidade de São Paulo

\section{ALTERNATIVAS PARA A PRODUÇÃO DE HIDROGÊNIO \\ NAS REGIÕES BRASILEIRAS VISANDO À \\ GERAÇÃO DE ENERGIA ELÉTRICA DISTRIBUÍDA}

PAULO BERNARDI JUNIOR

Tese apresentada como parte dos Requisitos para obtenção do Grau de Doutor em Ciências na área de Tecnologia Nuclear - Aplicações.

Orientador:

Profa. Dra. Fátima Maria Sequeira de Carvalho. 


\title{
ipen
}

INSTITUTO DE PESQUISAS ENERGÉTICAS E NUCLEARES

Autarquia associada à Universidade de São Paulo

\author{
ALTERNATIVAS PARA A PRODUÇÃO DE HIDROGÊNIO \\ NAS REGIÕES BRASILEIRAS VISANDO À \\ GERAÇÃO DE ENERGIA ELÉTRICA DISTRIBUÍDA
}

PAULO BERNARDI JUNIOR

Tese apresentada como parte dos

Requisitos para obtenção do Grau

de Doutor em Ciências na área de

Tecnologia Nuclear - Aplicações.

Orientador:

Profa. Dra. Fátima Maria Sequeira de Carva

SÃO PAULO 


\section{DEDICATÓRIA}

Em memória de meu amado pai Paulo Bernardi 


\section{Agradecimentos}

Agradeço o eterno apoio de minha amada esposa, ao IPEN pela oportunidade,

à Profa. Dra. Fátima Maria Sequeira de Carvalho pela paciência, orientação e incentivo que foram fundamentais para a execução deste trabalho. 


\title{
ALTERNATIVAS PARA A PRODUÇÃO DE HIDROGÊNIO NAS REGIÕES BRASILEIRAS VISANDO À GERAÇÃO DE ENERGIA ELÉTRICA DISTRIBUÍDA
}

\section{Paulo Bernardi Junior}

\begin{abstract}
RESUMO
Neste trabalho foram selecionadas, estabelecidas e estimadas possíveis fontes de produção de hidrogênio para a geração de energia elétrica de forma distribuída, com a utilização de célula a combustível. Estudaram-se três fontes de geração de energia renovável no Brasil: a biomassa, a energia solar fotovoltaica e a energia eólica. Para o estabelecimento dos valores numéricos foram avaliadas as principais culturas agrícolas de cada estado pertencente à respectiva região e a quantidade de biomassa, na forma de rejeito agrícola, capaz de ser gerada para futura utilização na produção de hidrogênio. Da mesma maneira foi investigada e avaliada numericamente a capacidade de produção de hidrogênio através das energias eólica e solar fotovoltaica para cada região do Brasil, tomando-se como base o processo de eletrólise. Mediante os resultados obtidos é possível demonstrar as potencialidades do Brasil para a geração de energia elétrica de maneira distribuída e com a substituição de combustíveis fósseis e por conseqüência, com a melhoria do meio ambiente.
\end{abstract}




\title{
ALTERNATIVES FOR THE HYDROGEN PRODUCTION IN THE BRAZILIAN REGIONS AIMING AT TO GENERATION OF DISTRIBUTED ELECTRIC ENERGY
}

\section{Paulo Bernardi Júnior}

\begin{abstract}
SUMMARY
In this work they had been selected, established and possible estimates sources of hydrogen production for the generation of electric energy of distributed form, with the fuel cell use. They had been studied being overcome three sources of generation of renewable energy in Brazil: the biomass, the photo-voltaic and wind resources energies. For the establishment of the numerical values the main agricultural cultures of each pertaining state to the respective and region the amount of biomass had been evaluated, in the form of reject agriculturist, capable to be generated for future use in the hydrogen production. In the same way it was investigated and evaluated numerically the capacity of hydrogen production through the energies, wind resources and photo-voltaic for each region of Brazil, being overcome as base the electrolysis process. By means of the gotten results it is possible to demonstrate the potentialities of Brazil for the generation of electric energy in distributed way and with the fossil fuel substitution, and, for consequence with the improvement it environment.
\end{abstract}




\section{SUMÁRIO}

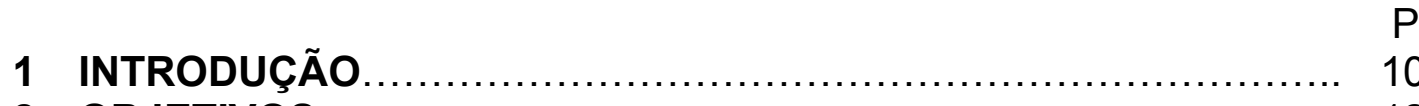

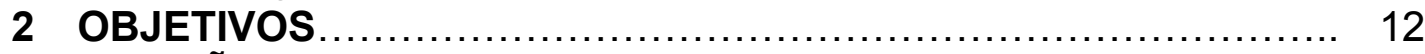

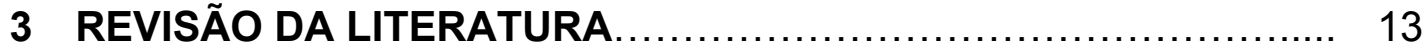

3.1 Principais Fontes Renováveis de Energia................................. 13

3.1.1 Energia Geotérmica...................................................... 14

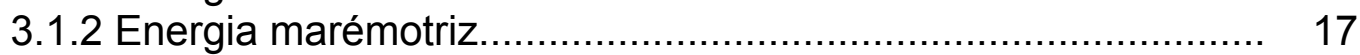

3.1.3 Energia Eólica............................................................ 19

3.1.3.1 Aerogeradores......................................................... 20

3.1.3.2 Funcionamento dos aerogeradores...................................... 21

3.1.4 Energia solar fotovoltaica................................................. 25

3.1.4.1 Fluxo de radiação solar.................................................. 26

3.1.5 Energia Hidroelétrica........................................................ 33

3.1.6 Energia do Hidrogênio...................................................... 34

3.1.6.1 Células a combustível................................................... 35

3.1.6.1.1 Tipos de células a combustível...................................... $\quad 40$

3.1.6.1.2 Célula Alcalina - AFC ................................................. 41

3.1.6.1.3 Célula de membrana de troca de prótons - PEMFC.......... 43

3.1.6.1.4 Célula a metanol direto - DMFC.................................... 45

3.1.6.1.5 Célula de Ácido Fosfórico - PAFC................................ 45

3.1.6.1.6 Célula de carbonato fundido - MCFC............................. 48

3.1.6.1.7 Célula de Óxido sólido - SOFC..................................... 50

3.1.6.1.8 Células a combustível regenerativas................................ 52

3.1.6.1.9 Células a combustível de cerâmica protônica..................... 52

3.1.6.2 Métodos de obtenção de hidrogênio...................................... 54

3.1.6.2.1 Eletrólise ............................................................ 54

3.1.6.2.1.2 Eletrolisadores unipolares com eletrólito líquido alcalino

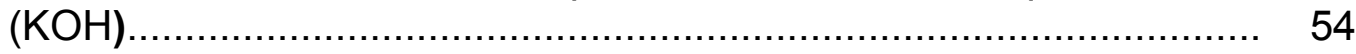

3.1.6.2.1.3 Eletrolisadores bipolares com eletrólito líquido alcalino

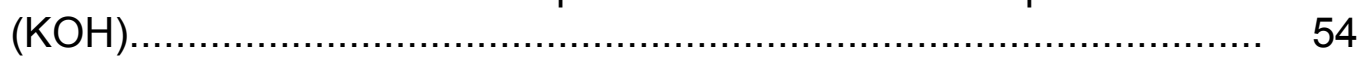

3.1.6.2.1.4 Eletrolisadores com eletrólito sólido (PEM).................... 55

3.1.7 Gaseificação da Biomassa.................................................. 58

3.1.7.1 Gaseificador contracorrente............................................. 61

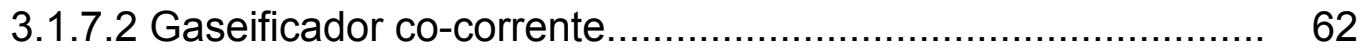

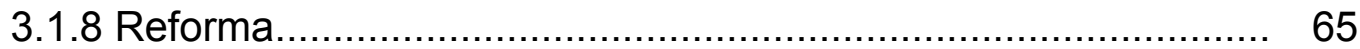

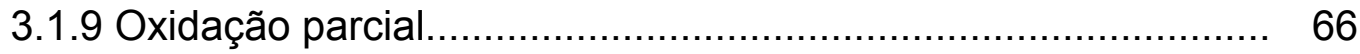

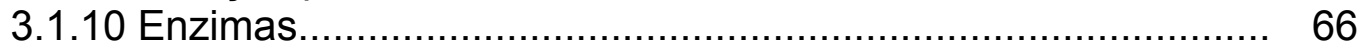

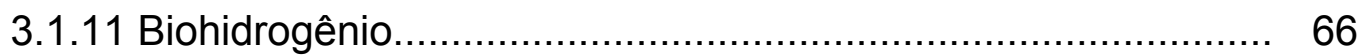

3.2 Situação atual da eletricidade no Brasil..................................... 67

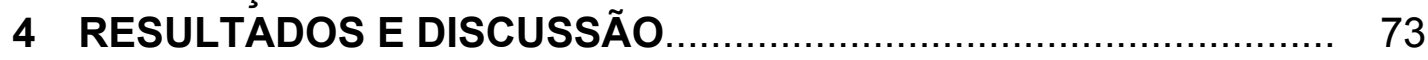

4.1 Quantidade de resíduos para gaseificação................................. 73

4.2 Região Nordeste............................................................... 76 
4.2.1 Vegetação da região Nordeste................................. 77

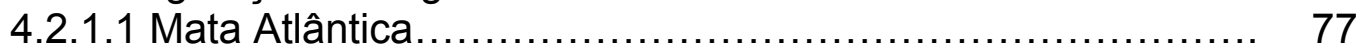

4.2.1.2 Mata dos Cocais............................................... 77

4.2.1.3 Cerrado..................................................... 77

4.2.1.4 Caatinga................................................................. 78

4.2.1.5 vegetação litorânea e matas ciliares..................................... 78

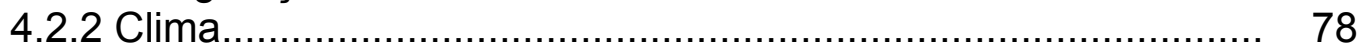

4.2.2.1 Clima equatorial úmido.................................................. 78

4.2.2.2 Clima litorâneo úmido.................................................. 78

4.2.2.3 Clima tropical........................................................... 79

4.2.2.4 Clima tropical semi-árido................................................ 79

4.2.3 Avaliação da produção de resíduos da região Nordeste por estado.

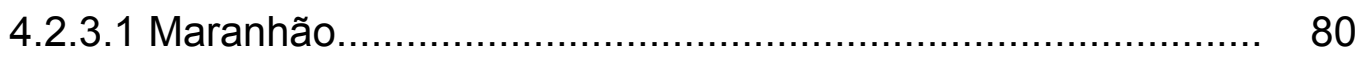

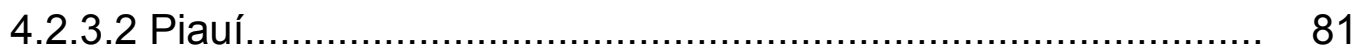

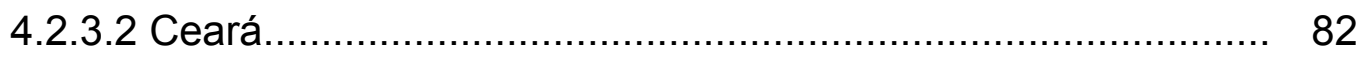

4.2.3.3 Rio Grande do Norte.................................................... 83

4.2.3.4 Paraíba........................................................................ 84

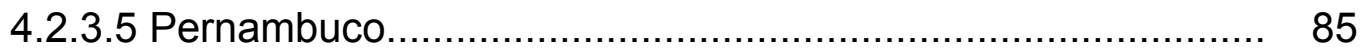

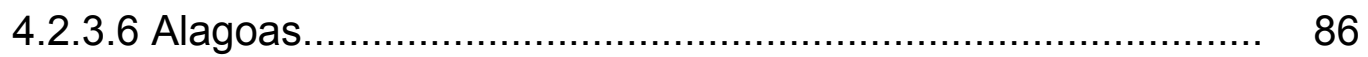

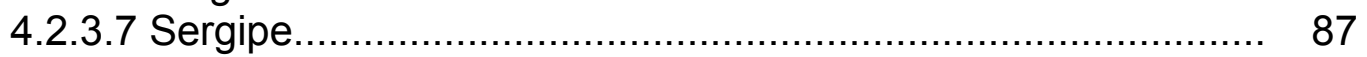

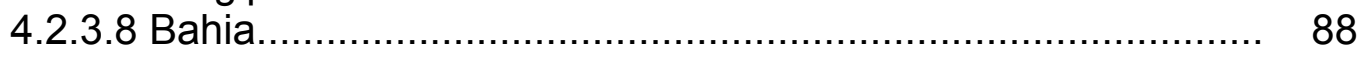

4.3 Região Norte............................................................. 90

4.3.1 Vegetação da região Norte................................................... 91

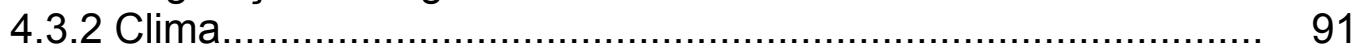

4.3.3 Hidrologia ................................................................... 92

4.3.4 Avaliação da produção de resíduos da região Norte por estado.

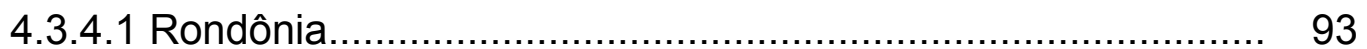

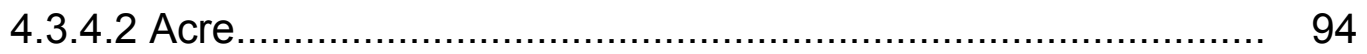

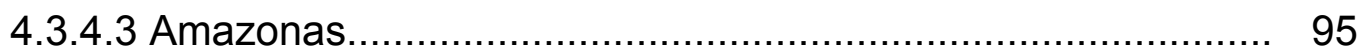

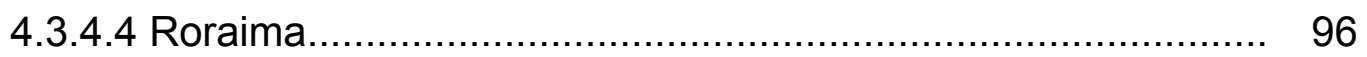

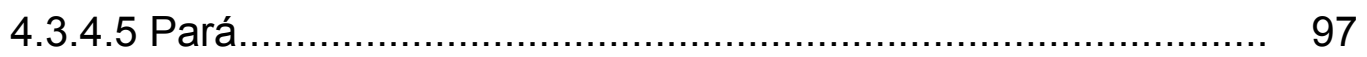

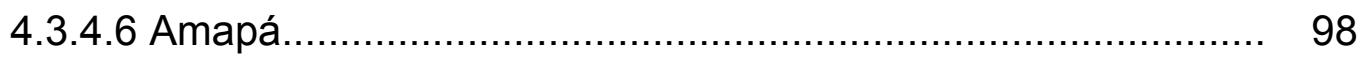

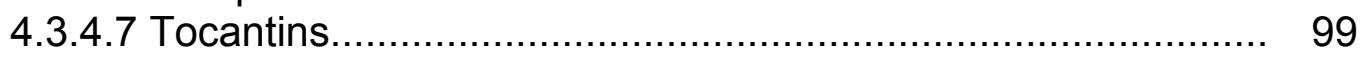

4.4 Região Centro-Oeste.......................................................... 101

4.4.1 Vegetação...................................................................... 102

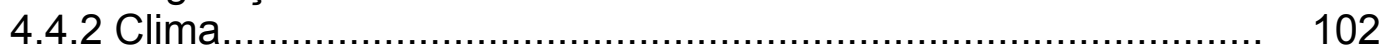

4.4.3 Hidrologia............................................................................. 103

4.4.4 Avaliação da produção de resíduos da região Centro-Oeste

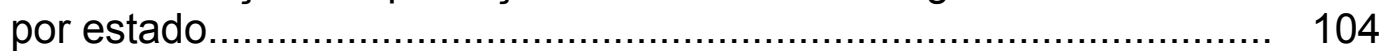

4.4.4.1 Mato Grosso do Sul..................................................... 104

4.4.4.2 Mato Grosso....................................................................... 105 
4.4.4.3 Goiás...................................................... 106

4.4.4.4 Distrito Federal.............................................. 107

4.5 Região Sudeste....................................................... 108

4.5.1 Vegetação....................................................................... 109

4.5.2 Clima..................................................................... 110

4.5.3 Hidrologia....................................................................... 111

4.5.4 Avaliação da produção de resíduos da região Sudeste por 113 estado.

4.5.4.1 Minas Gerais............................................................... 113

4.5.4.2 Espirito Santo......................................................... 114

4.5.4.3 Rio de Janeiro......................................................... 115

4.5.4.4 São Paulo.................................................................. 116

4.6 Região Sul................................................................... 118

4.6.1 Vegetação................................................................... 119

4.6.2 Clima........................................................................... 120

4.6.3 Avaliação da produção de resíduos da região Sul por estado... 121

4.6.3.1 Paraná....................................................................... 121

4.6.3.2 Santa Catarina.......................................................... 122

4.6.3.3 Rio Grande do Sul....................................................... 123

4.7 Avaliação do potencial de produção de hidrogênio nas diferentes regiões brasileiras a partir da biomassa.

4.8 Avaliação do potencial da energia fotovoltaica para a produção de hidrogênio por região...

4.9 Avaliação do potencial da energia eólica para a produção de hidrogênio por região.

4.10 Cálculos para a produção de energia a partir do hidrogênio produzido pelos três sistemas avaliados.

4.10.1 Quantidade de energia gerada a partir da biomassa...............

4.10.2 Quantidade de energia gerada a partir da energia fotovoltaica.

4.10.3 Quantidade de energia gerada a partir da energia eólica......

4.11 Avaliação do potencial total de produção de energia por tecnologia avaliada e por região.

4.12 Avaliação do custo de produção de energia por tecnologia avaliada 


\section{INTRODUÇÃO}

O meio ambiente e sua preservação aliados às necessidades do ser humano, levantam novos desafios que necessitam de uma abordagem ampla e interdisciplinar, onde as novas tecnologias e a reformulação ou aperfeiçoamento das já conhecidas são de fundamental importância.

Das necessidades básicas por que passa o ser humano destaca-se como de primordial importância para sua sobrevivência e para satisfação de outros requisitos como saúde, educação, segurança, trabalho e lazer, o acesso à energia elétrica. O homem moderno é cada vez mais dependente dos recursos energéticos para a sua sobrevivência e, por esse motivo, é fundamental que o acesso a esse recurso seja cada vez mais facilitado às populações mais carentes.

O grande consumo de combustíveis fósseis pela sociedade moderna tem levado o planeta a uma degradação sem precedentes do seu ambiente, principalmente relacionados ao efeito estufa. No Brasil a geração de energia hidrelétrica é também causadora de enormes impactos ambientais devido às grandes áreas que precisam ser alagadas para a construção de usinas hidrelétricas, retirando terras que, além de servirem de local de sobrevivência para inúmeras espécies, poderiam também ser usadas para a produção de alimento. É importante ainda lembrar que os grandes reservatórios em áreas tropicais levam à grande decomposição de vegetação, liberando assim grandes quantidades de metano e gás carbônico.

Devido à veloz urbanização sofrida pelas cidades no Brasil, a maioria dos recursos disponíveis para a geração de energia está muito afastada dos locais de consumo, gerando assim custos para o seu transporte. É importante lembrar que esse transporte também é provocador de significativos impactos ambientais, já que linhas de transmissão a grandes distâncias implicam em utilização de extensas faixas de terreno, levando assim a desmatamentos e conseqüente alteração do ambiente local. 
Tomando como ponto de partida essas premissas e lembrando ainda que muitas das regiões do nosso país já apresentam certa exaustão dos recursos para geração de eletricidade, elaborou-se esta proposta de trabalho que visualiza alternativas para a geração distribuída, a fim de atender às necessidades básicas dessas localidades com a utilização de um sistema que não comprometa o meio ambiente.

O presente trabalho se propõe a avaliar os principais sistemas de produção de hidrogênio possíveis para a implantação de células a combustível, como fontes geradoras de energia elétrica, no local de consumo (geração distribuída). Esta proposta vem ao encontro, por um lado, à preservação do ambiente natural em áreas não degradadas e, por outro lado, abre a possibilidade do aumento da produção de energia sem o aumento da pressão de degradação sobre o meio ambiente.

Devemos lembrar ainda que a energia distribuída e de fácil acesso pode levar a uma radical mudança nos aspectos sociais das comunidades beneficiadas, diminuindo a pobreza e a migração para as grandes cidades. Outro aspecto é a diminuição da dependência do transporte e utilização de combustíveis fósseis, propiciando uma energia de boa qualidade. 


\section{OBJETIVOS}

Este estudo tem como objetivo avaliar a produção de hidrogênio, para utilização em células a combustível, com insumos existentes nas regiões brasileiras, como uma alternativa para a geração de energia elétrica de forma distribuída para estas regiões e sugerindo três diferentes métodos de produção de hidrogênio.

O foco desse trabalho é, portando, mostrar as possibilidades que são oferecidas por tecnologias renováveis em função das características regionais do nosso país. 


\section{REVISÃO DA LITERATURA}

\section{1 - Principais Fontes Renováveis de Energia}

Os atuais e futuros desenvolvimentos na economia nacional e mundial estão intimamente ligados a uma energia sustentável, eficiente e segura, com utilização de matérias-primas adequadas para a produção de energia mais limpa, baseada em conceitos ecologicamente adequados e economicamente viáveis, a curto médio e longo prazo, para o futuro da sociedade.

É crescente a importância das fontes renováveis de energia e a melhoria da eficiência como temas cruciais para os profissionais da indústria, para as tomadas de decisões governamentais, bem como para os prestadores de serviço civis, pesquisadores e educadores. $O$ aquecimento global relacionado com as emissões de $\mathrm{CO}_{2}$, juntamente com o forte incremento dos preços da energia, causa enormes preocupações na sociedade e dá origem a um aumento na busca de maneiras de se melhorar a vida do ser humano com relação à eficiência energética.

Até recentemente, os melhoramentos com relação à energética industrial têm-se centrado em melhorias na eficiência em detrimento da integração de fontes renováveis ${ }^{1}$. Atualmente, os trabalhos se voltam mais à parte ambiental e incluem foco nas formas de:

(a) Melhoria do processo industrial para otimização da eficiência energética.

(b) Minimização de resíduos e redução de seu impacto por meio de uma boa gestão.

(c) Redução das emissões de $\mathrm{CO}_{2}$, fazendo progresso em direção a sistemas baseados em energia renovável,

(d) Melhoria na produção de bio-combustíveis e sistemas de produção de hidrogênio

(e) Melhoria na integração de materiais avançados e equipamentos energeticamente eficientes em diferentes setores industriais. 
Estes desafios têm recebido atenção considerável nos meios de comunicação e revistas científicas nos últimos anos.

\subsection{1 - Energia Geotérmica}

A energia geotérmica existe desde que o nosso planeta foi criado. Geo significa terra e térmica significa calor, por isso, geotérmica é a energia calorífica que vem da terra. para a geração de eletricidade No interior da Terra encontramos o magma, que é constituido, principalmente, de rochas derretidas. A crosta terrestre flutua nesse magma.

Com o aumento da profundidade a temperatura dessas rochas aumenta cada vez mais. Por vezes, o magma quebra a crosta terrestre chegando à superfície. A este fenômeno natural chama-se vulcão e o magma passa a designar-se lava. A cada 100 metros de profundidade a temperatura aumenta $3^{\circ}$ Celsius. Na Algéria, por exemplo, há regiões que atingem cerca de $118^{\circ} \mathrm{C}^{2}$.

Existem locais, as furnas, onde a água quente sobe até á superfície terrestre formando pequenos lagos.

A primeira tentativa de gerar eletricidade de fontes geotérmicas se deu em 1904 em Larderello na região da Toscana, na Itália. Contudo, esforços para produzir uma máquina para aproveitar tais fontes foram mal sucedidos, pois as máquinas utilizadas sofreram destruição devido à presença de substâncias químicas contidas no vapor. Já em 1913, uma estação de 250 kW obteve sucesso e 100 MW estavam sendo produzidos na época da Segunda Guerra Mundial, mas a usina foi destruída na Guerra ${ }^{3}$.

As principais vantagens da energia geotérmica são: permite poupar energia; relativamente barata; liberta menos gases poluentes para a atmosfera relativamente a outras fontes de energia não renováveis.

Apresenta também algumas desvantagens: se não for usada em zonas onde o calor do interior da Terra vem à superfície através de géiseres, então a perfuração dos solos para a introdução de canos é dispendiosa; os antigelificantes usados nas zonas mais frias são poluentes, pois apesar de terem uma baixa toxicidade, alguns produzem CFCs e HCFCs. Além disso, ao perfurar as camadas mais profundas, é possível que sejam libertados gases e minerais 
perigosos, o que pode pôr em risco a segurança das pessoas que vivem e trabalham perto desse local ${ }^{4}$.

Não existem muitos locais onde seja viável a instalação de uma central geotérmica, uma vez que é necessário um determinado tipo de solo, bem como a disponibilidade de temperatura elevada no local até onde seja possível perfurar. Mas mesmo quando não existem gêiseres, é possível estimular o aquecimento d'água usando o calor do interior da Terra. Um experimento realizado em Los Alamos, Califórnia, provou a possibilidade de execução deste tipo de usina ${ }^{5}$.

A FIG. 1 mostra as instalações de uma usina geotérmica construída em El Salvador ${ }^{6}$

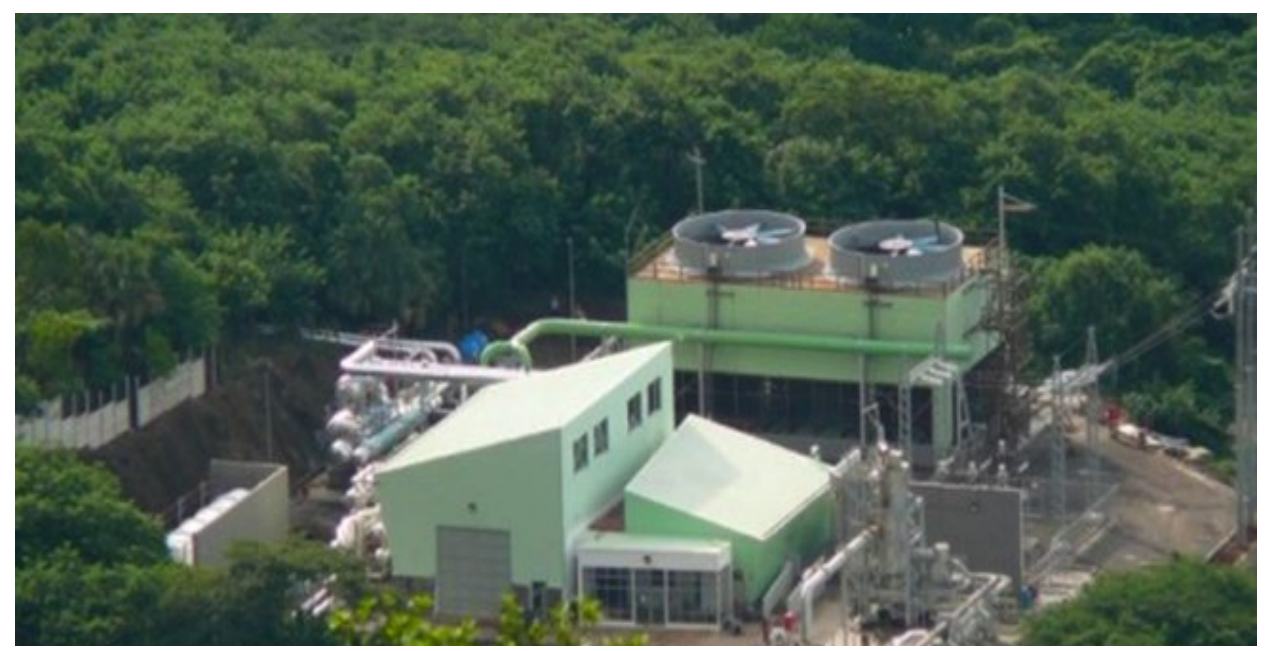

FIGURA 1: Usina geotérmica construída em El Salvador com tecnologia da Islândia ${ }^{6}$.

Uma bomba de calor geotérmica pode transferir calor armazenado na Terra sem serem necessárias condições geológicas especiais, tais como fontes termais. A tecnologia está bem estabelecida na América do Norte e em partes da Europa $^{7}$. Na Figura 2 mostra-se um esquema do funcionamento de uma usina geotérmica 


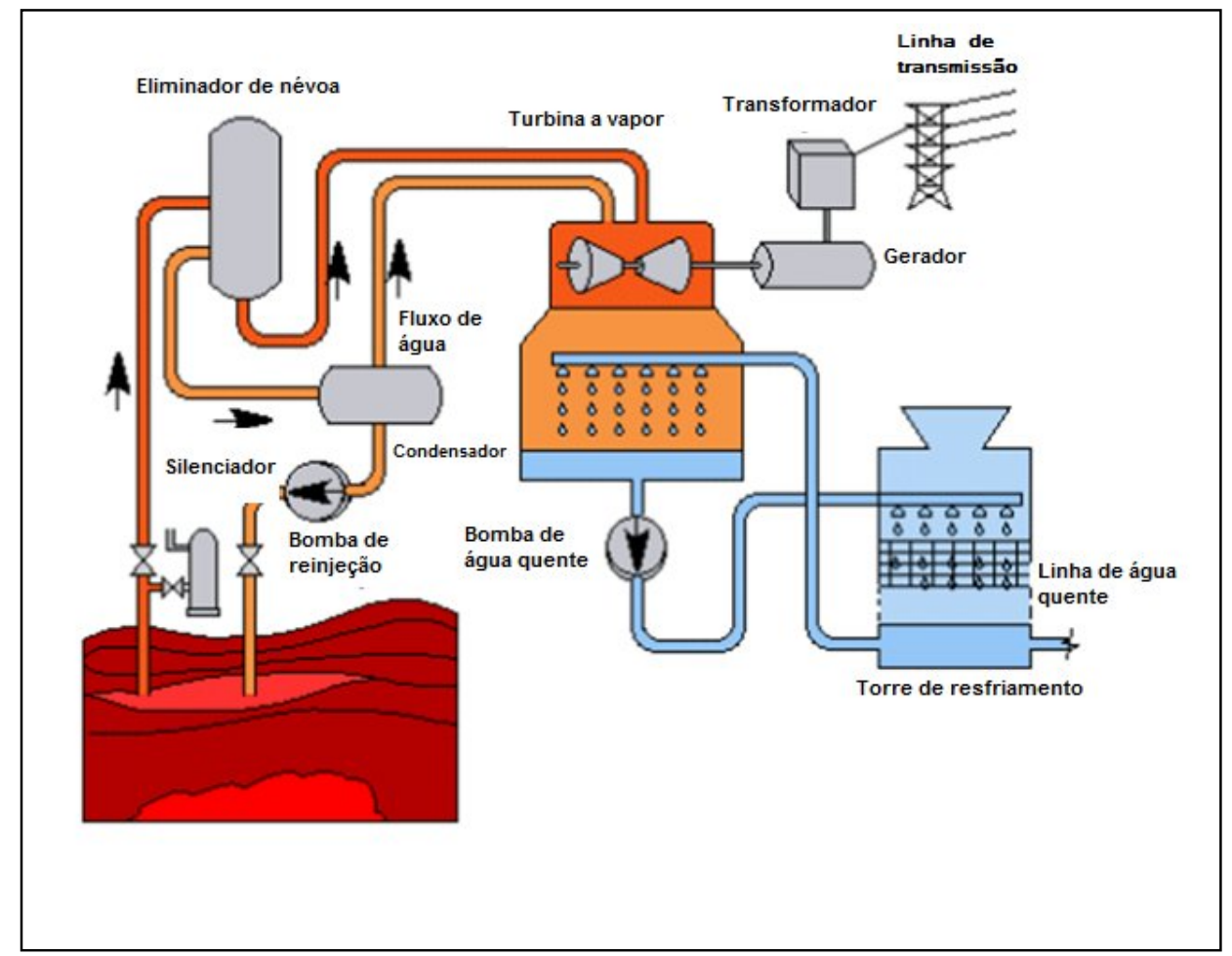

FIGURA 2: Esquema de funcionamento de uma usina geotérmica ${ }^{8}$.

Através destes tubos o vapor é conduzido até a central elétrica geotérmica. Tal como numa central elétrica normal, o vapor faz girar as lâminas da turbina como uma ventoinha. A energia mecânica da turbina é transformada em energia elétrica através do gerador. A diferença destas centrais elétricas é que não é necessário queimar um combustível para produzir eletricidade.

Após passar pela turbina o vapor é conduzido para um tanque onde vai ser arrefecido. O vapor transforma-se novamente em água no processo de arrefecimento, que é novamente canalizada para o reservatório onde será naturalmente aquecida pelas rochas No Japão há previsão de se instalar 140.000 sistemas de bombas de calor geotérmico até $2010^{9}$.

No Brasil não existem projetos para a instalação de usinas geotérmicas em função das características de formação e idade de nosso terreno, fazendo com que as regiões de magma estejam muito profundas ${ }^{10}$. 


\subsubsection{Energia maremotriz}

Assim como a que se origina dos ventos e do sol, a energia vinda das águas dos oceanos é classificada como limpa e auto-sustentável. No entanto, não é ainda um recurso muito explorado.

A superfície do oceano oscila entre pontos altos e baixos, chamados marés, a cada $12 \mathrm{~h}$ e $25 \mathrm{~min}$. Esse movimento das águas chega, em alguns lugares do mundo, a atingir uma altura de mais de 17 metros. A energia maremotriz, obtida de modo semelhante à hidrelétrica, é o modo de geração de eletricidade através da utilização da energia contida no movimento de massas de água devido às marés ${ }^{11,12}$.

Dois tipos de energia maremotriz podem ser obtidas: pela energia cinética das correntes devido às marés, o modelo "seaflow" e pela energia potencial devido à diferença de altura entre as marés alta e baixa, o modelo de represa. Khan e colaboradores apresentam uma revisão sobre artigos que tratam desse assunto $^{13}$.

As pesquisas relacionadas ao modelo "seaflow" estão ainda em fase inicial, mas são alvo de estudos de pesquisadores britânicos que querem desenvolver turbinas para fabricação em escala comercial. O projeto consiste em turbinas instaladas em pleno oceano, que são movimentadas pela velocidade das águas aceleradas pelo movimento das marés. As correntes marítimas impulsionadas pelos ventos produzem uma energia cinética pouco densa e difícil de ser explorada. Os melhores locais para exploração desse tipo de energia são os estreitos, como o Estreito de Gibraltar.

No modelo de represa aproveita-se da diferença do nível de água entre as marés alta e baixa como mostrado na FIG. 3 , sendo necessário o represamento de água em estuários ou baías. Para isso, os locais onde se deseja implementar esse tipo de tecnologia devem ter uma situação geográfica favorável. 


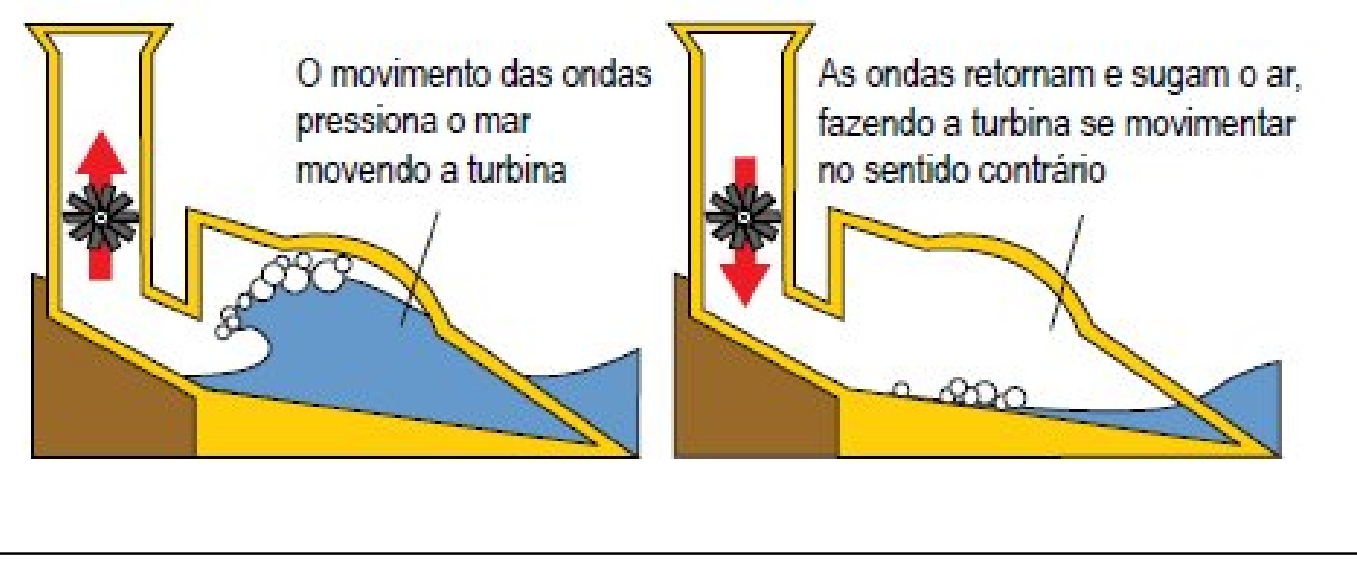

FIGURA 3: Funcionamento de usina com energia das marés ${ }^{10}$.

Trata-se de uma obra complexa de engenharia hidráulica. O processo de geração é efetuado nos dois sentidos de passagem de água. Constrói-se uma barragem, formando-se um reservatório junto ao mar. Quando a maré está alta, abrem-se as comportas e a água enche o reservatório, passando através da turbina hidráulica, produzindo energia elétrica. Na maré baixa, o reservatório é esvaziado, aproveitando, assim, a energia potencial do nível da água e a água que sai do reservatório passa novamente através da turbina, em sentido contrário, produzindo a energia elétrica.

Antes de 1500 foi construída uma usina maremotriz em Lameiras, município de Sintra, Portugal, para uso direto em moendas. Mas a primeira usina deste tipo para a geração de energia elétrica em larga escala foi a de La Rance, França, em 1966, sendo até hoje a que produz mais energia elétrica ${ }^{11,12}$.

Este tipo de fonte é também utilizado no Japão, na Inglaterra e no Havaí. Existem usinas maremotrizes em construção, ou sendo planejadas, no Canadá, México, Reino Unido, Estados Unidos e Argentina.

Apesar de ter impactos ambientais menores que os provocados pela exploração de combustíveis fósseis, por se tratar de uma fonte alternativa, na geração maremotriz de energia elétrica estes são relativamente grandes, pois por envolver a construção de uma barragem, a modificação no ecossistema marinho local é inevitável.

Como as marés se revezam em intervalos de 6 em 6 horas, mais ou menos, a produção de energia se limita a esse revezamento, o que faz com que a produção efetiva seja bem menor que a capacidade da instalação. Além disso, os 
custos de implementação de uma barragem desse porte são elevadíssimos, pois a água salgada, devido a seu elevado poder de corrosão, exige a utilização de materiais especiais na construção dos equipamentos, o que encarece sobremaneira a implantação e a manutenção desse tipo de unidade geradora.

O Brasil apresenta condições favoráveis à implementação desse sistema em locais como São Luiz, no litoral maranhense, onde a amplitude dos níveis das marés chega a oito metros. Os estados do Pará e do Amapá também apresentam condições favoráveis para esse sistema. Apesar disso, ainda não existe nenhuma usina maremotriz no Brasil. Na COPPE/UFRJ, pesquisadores do Laboratório de Tecnologia Submarina visam o estudo e implementação de uma usina de geração de energia elétrica através do balanço das ondas no litoral Cearense. Essa usina deve entrar em funcionamento em 3 anos e deve gerar 400MW em sua primeira fase. Trata-se do primeiro projeto nesse nível no Brasil ${ }^{14}$.

\subsubsection{Energia eólica}

A energia eólica é a proveniente das movimentações das massas de ar, causadas pelo aquecimento das mesmas pela energia do sol e seu respectivo reflexo nas superfícies onde incide.

Sabe-se que fora a energia nuclear e geotérmica todas as outras formas de energia fundamentalmente são originadas do sol.

O sol manda para a terra o equivalente a $1,2 \times 10^{17} \mathrm{~W}$ de potência, sendo que 1 a $2 \%$ são convertidos em energia cinética através da movimentação de massas de ar (vento) ${ }^{15}$.

Vários fatores influenciam a movimentação dessas massas de ar, tais como altitude, localização geográfica (latitude e longitude) e tipo de vegetação dos arredores, mudando assim a rugosidade do terreno.

Não existe registro preciso do início do aproveitamento da energia eólica, porém indícios levam a milhares de anos atrás no Oriente ${ }^{16}$.

Acredita-se que graças à energia eólica foram possíveis as grandes navegações na idade média e máquinas eólicas foram, provavelmente, construídas na Europa no século $\mathrm{XI}^{17}$. 
O que se sabe com certeza é que na Holanda desde o século XIV muito se utilizam moinhos movidos a energia eólica. O aperfeiçoamento da utilização da energia eólica foi gradual durante séculos, sofrendo apenas declínio quando do aprimoramento da máquina a vapor ${ }^{17}$.

O renascimento da utilização da energia eólica ocorreu com os cataventos multipás apenas no século XIX, nos Estados Unidos da América, com a abolição dos escravos e a conseqüente necessidade de bombeamento de água ${ }^{17}$.

Como sistema de geração de energia elétrica foi utilizada pela primeira vez na década de 30 nos Estados Unidos da América tendo, como mola mestra para o desenvolvimento atual, as crises do petróleo nas décadas de 70 e $80^{18}$.

A utilização da energia eólica para geração de energia elétrica cresce a uma taxa anual de 25\% desde 1990 e atinge o seu ápice como forma de geração renovável em países como a Dinamarca, Alemanha e Espanha.

\subsubsection{Aerogeradores}

Os aerogeradores são equipamentos capazes de transformar a energia cinética contida no vento em energia elétrica. Ao longo de séculos esses equipamentos foram sendo aprimorados, até que hoje podemos contar com aerogeradores de mais de $100 \mathrm{~m}$ de altura com pás que chegam a $75 \mathrm{~m}$ de diâmetro, podendo gerar até $5 \mathrm{MW}$ de potência, maximizando assim 0 aproveitamento do vento.

Vários modelos e tamanhos de aerogeradores têm sido testados em diversas partes do mundo, com variações principalmente em relação ao número de pás e também quanto ao posicionamento do rotor (vertical ou horizontal).

Podemos ver na FIG. 4 a variedade de modelos de aerogeradores que já foram testados em diversas partes do mundo. 

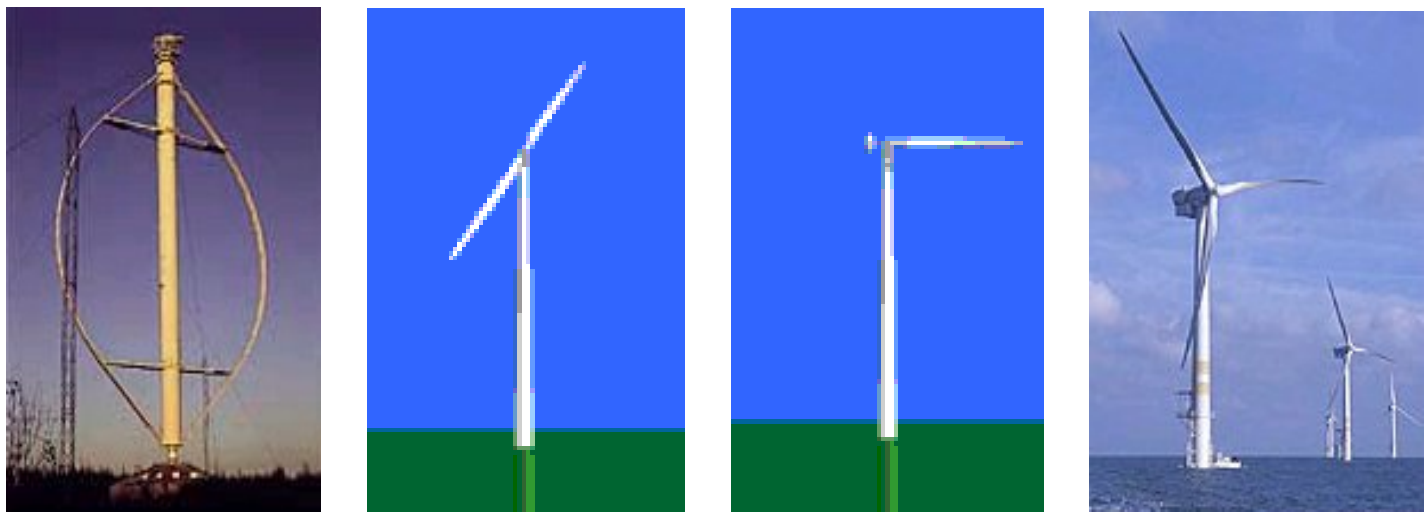

FIGURA 4: Modelos de aerogeradores $^{18}$.

Apesar das variações vistas acima o conceito de turbina eólica que é utilizado atualmente é o de três pás, conceito esse que foi elaborado pelo engenheiro Johannes Juul llegó na década de 50 na Dinamarca ${ }^{19}$.

\subsubsection{Funcionamento dos aerogeradores}

A FIG. 5 mostra as principais partes que formam uma turbina eólica de ultima geração, sendo que o funcionamento de cada parte está descrito com a numeração correspondente. 


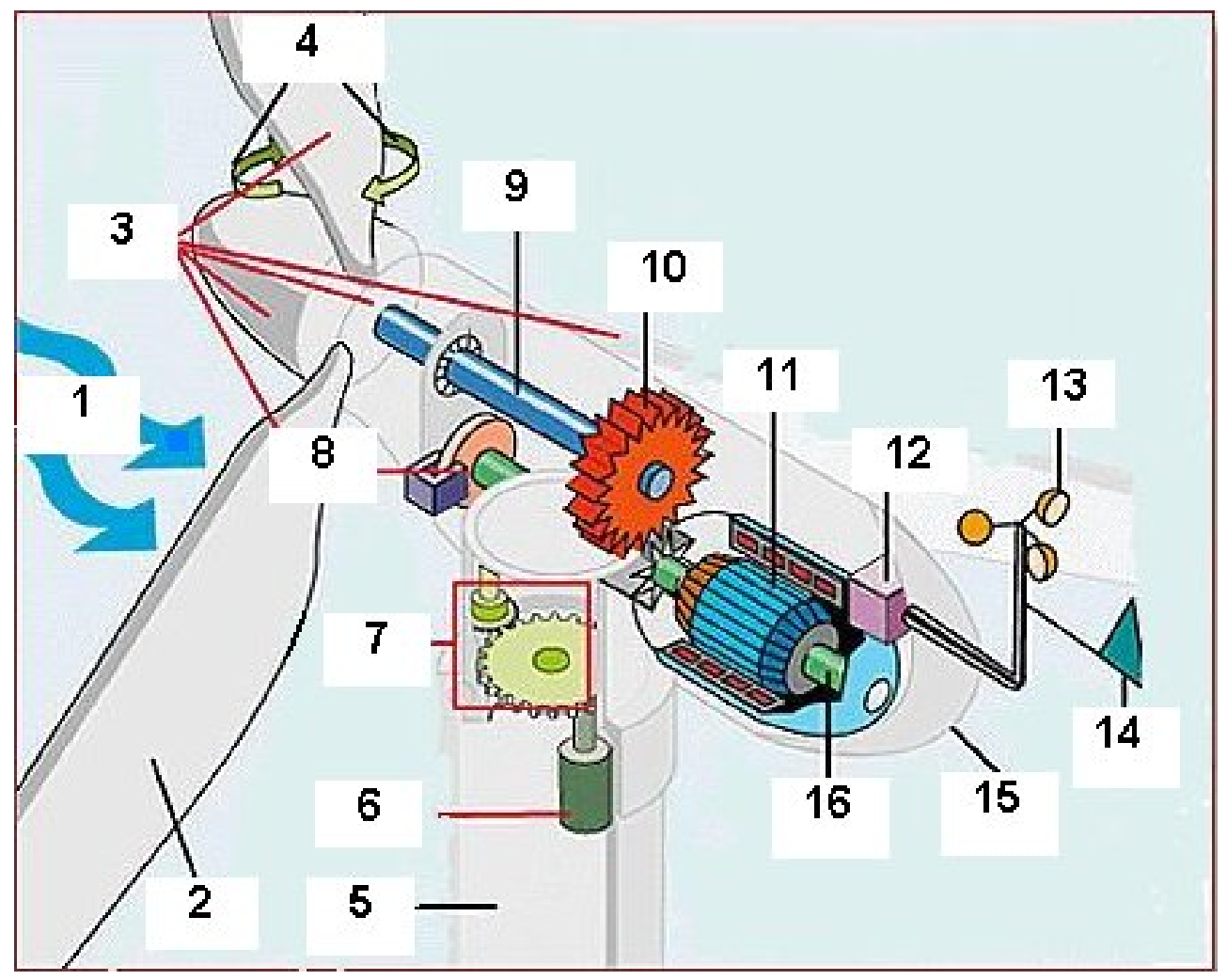

FIGURA 5: Partes integrantes de uma turbina eólica ${ }^{20}$.

1-Direção do Vento: Nesse tipo de turbina o rotor sempre está de frente para o vento devido à sua capacidade de se posicionar automaticamente.

2-Pás: $O$ vento passa através da superfície das pás deixando parte de sua energia cinética nas mesmas e causando assim a rotação.

3-Rotor: Recebem esse nome as pás e o eixo principal da turbina eólica.

4-Movimento angular: As pás podem mudar o seu "ângulo de ataque" em relação ao vento para mudar a velocidade de giro em caso de ventos muito fortes ou muito fracos, melhorando o desempenho e protegendo a turbina.

5-Torre: É o suporte de todo o mecanismo móvel da turbina. São feitas normalmente de aço na forma de tubo ou cone, podendo ser também de concreto.

6-Motor do sistema de direcionamento: Responsável por fornecer o movimento à caixa de direcionamento. 
7-Caixa de Direcionamento: É utilizada para mudar a direção do rotor mantendo-o sempre de frente para o vento, recebe informações dos sistemas de direcionamento localizados na própria turbina.

8-Freio: Sistema de freio a disco que pode ter acionamento elétrico, hidráulico ou mecânico e é utilizado para parar ou diminuir o giro do rotor.

9-Eixo de baixa velocidade: Ligado diretamente às pás gira em baixa velocidade, que pode ir de 25 a 60 rotações por minuto.

10-Caixa de Câmbio: É responsável pela ligação entre o eixo de baixa velocidade e o de alta velocidade, passando de 25 a 60 rotações por minuto para cerca de 1800 rotações por minuto, que é a velocidade necessária para o gerador entrar em funcionamento. É a parte mais cara e que necessita de maior manutenção em uma turbina eólica.

11-Gerador: Equipamento de indução que na maior parte das turbinas produz corrente alternada de 60 ciclos.

12-Controlador: É responsável pela partida da turbina quando a velocidade do vento alcança aproximadamente $10 \mathrm{Km} / \mathrm{h}$ e também é responsável pelo desligamento quando a velocidade do vento excede aproximadamente 70 $\mathrm{Km} / \mathrm{h}$.

13-Anemômetro: Aparelho utilizado para medir a velocidade do vento e transmitir essa informação para o controlador.

14-Asa de Direção: É responsável por detectar a direção do vento e transmitir a informação para a caixa de direcionamento, permitindo que essa se movimente de maneira correta para que o rotor permaneça sempre de frente para o vento.

15-Nacele: É a estrutura que contem todos os sistemas da turbina eólica com exceção das pás e da ponta do rotor.

16-Eixo de Alta Velocidade: Faz parte do eixo que movimenta o gerador em alta velocidade ${ }^{20}$.

A utilização do vento envolve o desenvolvimento de novos materiais, novas técnicas e novos métodos de modelagem matemática. As máquinas terão de ser mais confiáveis e robustas e vão exigir um sistema mais flexível para a alimentação em energia elétrica ${ }^{21}$. Modernos e sofisticados geradores eólicos com 
capacidade nominal de até $5 \mathrm{MW}$ estão em uso no mar em muitos países europeus, os quais exigem investimentos significativos. Assim, estão apurados os fatores que têm maior impacto sobre a viabilidade econômica dos projetos de energia eólica ${ }^{22}$.

Nos últimos anos encontram-se vários estudos sobre a energia eólica, seu custo, suas vantagens e desvantagens. Atualmente diferentes países têm buscado adaptar a energia eólica em seus territórios como fonte de energia alternativa limpa $23,24,25,26,27,28$.

O sistema de energia eólica não pode ser tecnicamente viável em todos os lugares, pois nem sempre se conta com alta velocidade do vento. Mas o uso combinado de fontes eólica e solar está cada vez mais atraente e sendo amplamente utilizado como alternativa de fornecimento de energia. $\mathrm{O}$ aspecto econômico destas tecnologias de energias renováveis conjuntas é suficientemente promissor para incluí-las em estudos devido à necessidade crescente de energia nos países em desenvolvimento ${ }^{29}$.

No Brasil a utilização do potencial de energia eólica é inexpressiva em relação a seu potencial e apenas poucos projetos na última década estão sendo avaliados. Dutra e $\mathrm{Szklo}^{30}$, considerando como alvo apenas promover uma tecnologia eólica para a indústria doméstica, estimam que a capacidade instalada poderia variar entre 29,1 e 217,1GW, dependendo do critério de seleção dos projetos. Ressaltam que é necessário avaliar com mais detalhes o funcionamento de turbinas em alta salinidade e abrasividade, condições que são comuns na costa brasileira, como ocorre nos sistemas "offshore". A utilização de pequenas turbinas eólicas em áreas remotas ou rurais brasileiras, por exemplo para 0 bombeamento de água, é outro interessante campo de estudo. 


\subsubsection{Energia solar fotovoltaica}

A quantidade de energia que a superfície da terra recebe em um dia é equivalente a $1,2 \times 10^{17} \mathrm{~W}^{31}$. Isso equivale a dizer que, em um minuto de insolação, a Terra recebe mais energia do sol do que se consome de energia em um ano no planeta, apesar dos fatores que causam a dispersão e absorção da radiação solar que atravessa a atmosfera terrestre, fazendo com que ocorra uma diminuição de sua potência. Dentre esses fatores, os principais são a água, na forma de nuvens, material particulado e gases, provocando uma reflexão de até $30 \%{ }^{24}$.

A FIG. 6 mostra as interações dos raios solares que podem incidir na superfície da terra, sendo que cada valor corresponde à fração de energia envolvida em cada situação ${ }^{32}$.

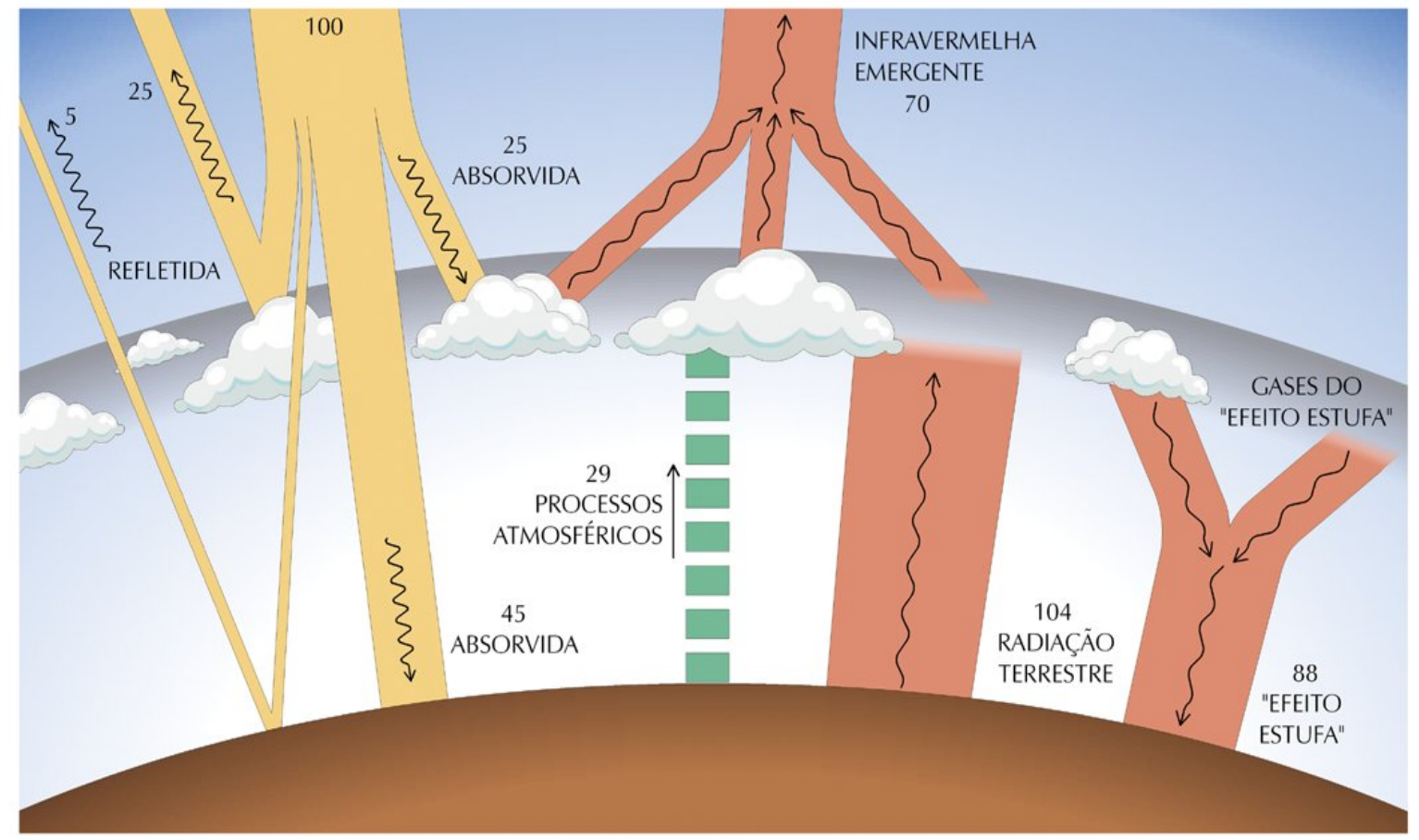

FIGURA 6: Incidência e interações dos raios luminosos sobre a terra ${ }^{32}$. 


\subsubsection{Fluxo de radiação solar.}

Para efetuar a medida da radiação solar na superfície da terra podem ser usados dois tipos básicos de modelagem, que são classificados como estatísticos e físicos ${ }^{32}$.

O modelo estatístico utiliza formulações empíricas das variações atmosféricas do local de medição e sua influência na radiação que incide sobre a superfície da terra. As respostas obtidas por esse modelo são limitadas à região estudada.

O modelo físico é o que resolve satisfatoriamente a equação da transferência de radiação (resolução matemática dos processos físicos existentes na atmosfera $)^{32}$.

O modelo utilizado para a obtenção dos dados solarimétricos em nosso país é o BRASIL-SR, desenvolvido a partir do modelo GKSS Forschungszentrum que é descrito por Stuhlman at al. ${ }^{33}$.

É usado também o índice que estabelece um valor para incidência dos raios luminosos em relação à terra, sendo conhecido por Massa de $\operatorname{Ar}(A M)$, que foi fixado com o valor igual a um $(A M=1)$, usando a seguinte fórmula: $\cos \theta_{z}$ onde $\theta_{z}$ corresponde a um ângulo zenital do sol, quando em dia claro sem nuvens. Para a efetuação dos cálculos de eficiência dos painéis fotovoltaicos é utilizado um valor de referência de $A M=1,5$. Além desses dois valores é utilizada mais uma variável se a célula fotovoltaica estiver inclinada em relação ao horizonte, essa variável é chamada de "albedo" e é dada pela reflexão do ambiente em torno da célula (solo, rochas, vegetação, etc. ${ }^{32}$. Os diferentes tipos de incidência sobre um painel fotovoltaico podem ser vistos na FIG. 7. 


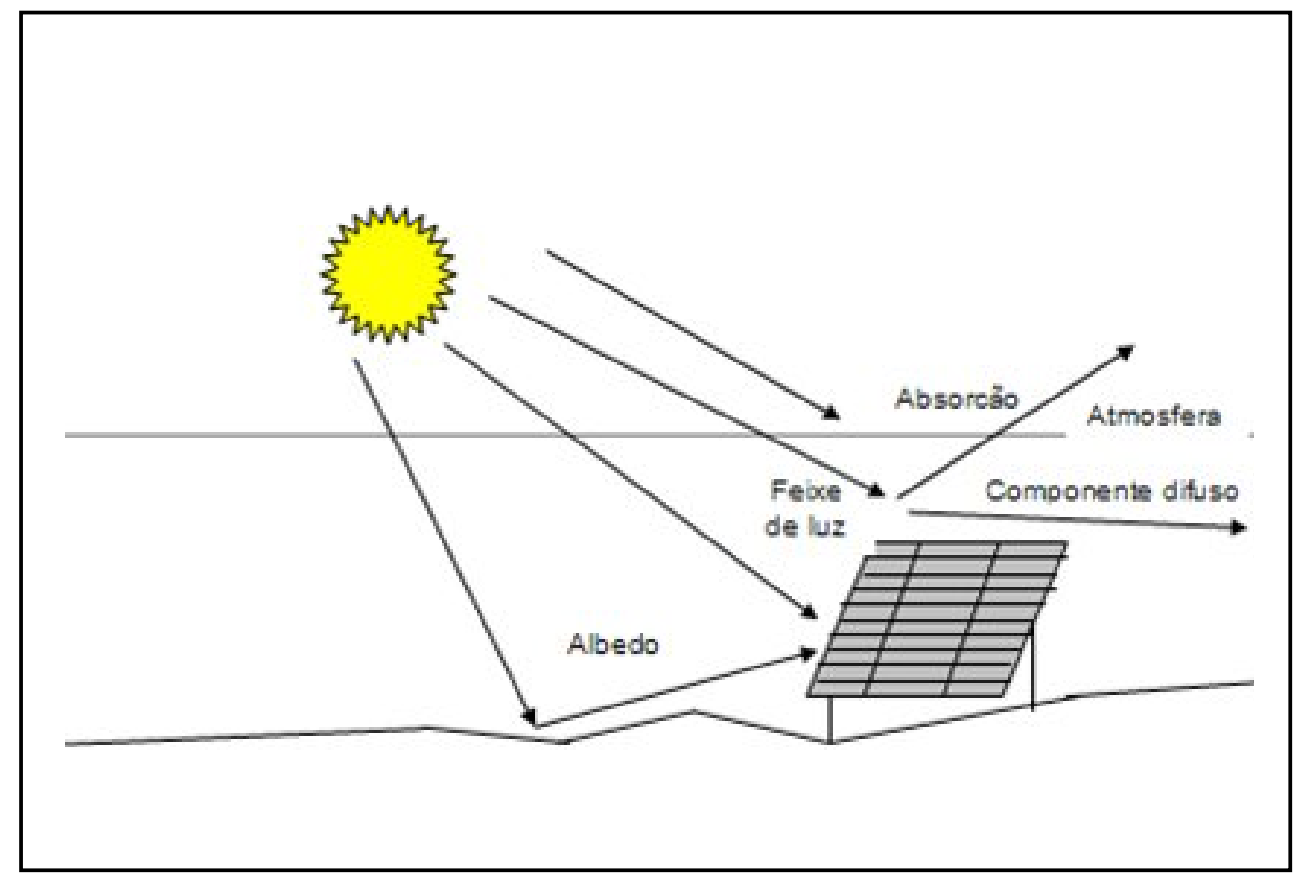

FIGURA 7: Incidências da luz solar sobre um painel fotovoltaico ${ }^{31}$.

O efeito fotovoltaico, onde é observada a conversão da luz em eletricidade, foi descrito pela primeira vez em 1839 por Alexandre Edmund Becquerel.

A aplicação prática dessa descoberta só foi ocorrer por volta de $1956^{23}$. Na TAB. 1 é possível visualizar os principais eventos relacionados ao fenômeno fotovoltaico 
TABELA 1: Evolução dos estudos sobre o efeito fotovoltaico

\begin{tabular}{|l|r|}
\hline 1839 & Becquerel descobre o efeito fotovoltaico. \\
\hline 1876 & Adams e Day observam o efeito fotovoltaico no selênio. \\
\hline 1900 & Planck postula a natureza quântica da luz. \\
\hline 1930 & Teoria quântica dos sólidos é proposta por Wilson. \\
\hline 1940 & Mot e Schottky desenvolvem a teoria retificadora do estado sólido (diodo). \\
\hline 1954 & Chapin, Fuller e Pearson comunicam ter alcançado 6\% de eficiência em \\
& \\
\hline 1954 & Reynolula solar de silício. \\
\hline 1958 & Pela primeira vez é usada uma célula solar no satélite Vanguard I. \\
\hline
\end{tabular}

O efeito fotovoltaico ocorre em materiais conhecidos como semicondutores, aos quais são adicionadas substâncias chamadas de dopantes que adicionam características especiais a eles, sendo depois dispostos em camadas sobre uma placa metálica, FIG. 8. 


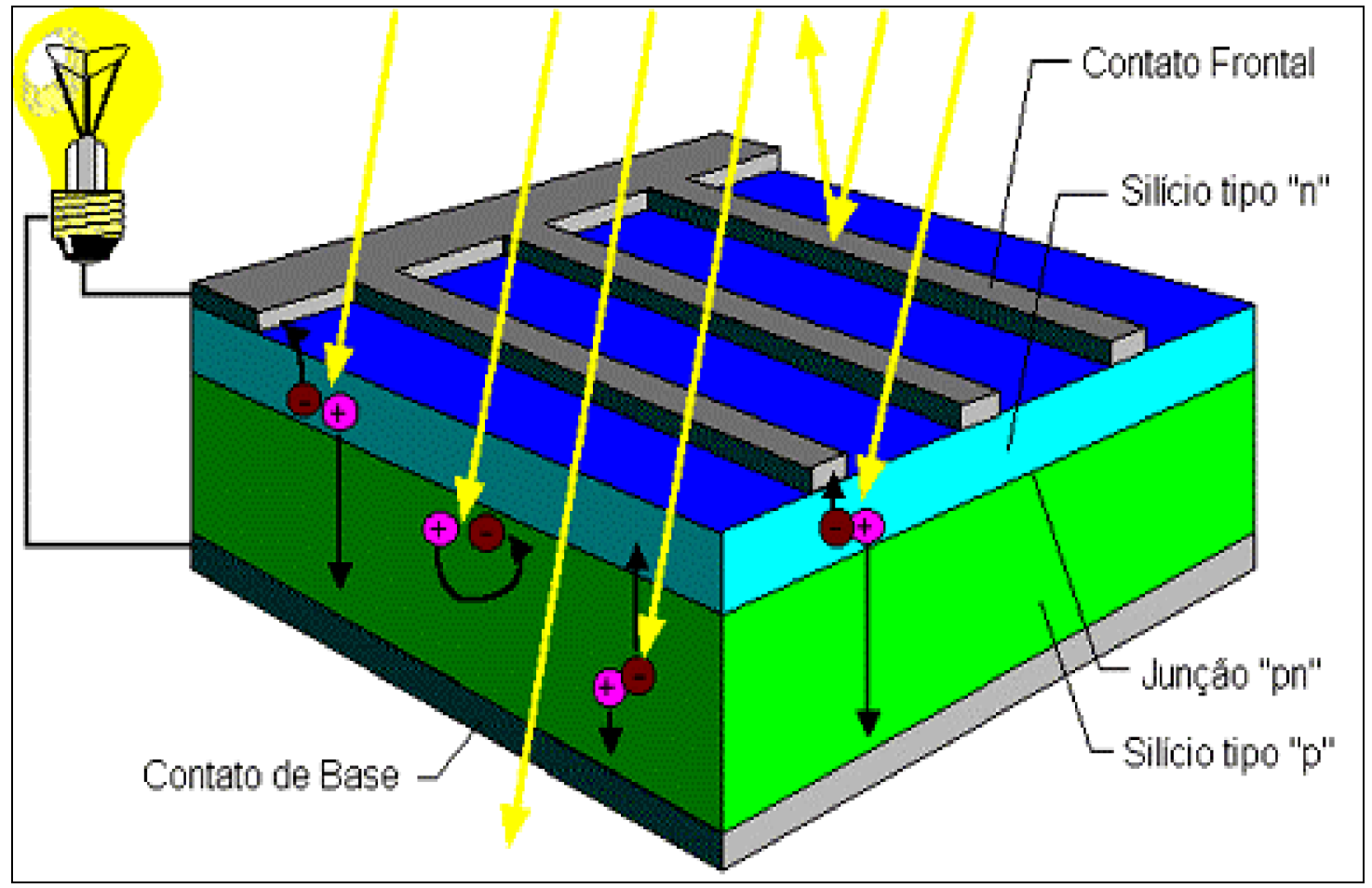

FIGURA 8: Célula fotovoltaica ${ }^{38}$.

O material mais utilizado na confecção das células que compõem um painel fotovoltaico é o silício. Esse elemento químico pode ser disposto de maneiras diferentes nas células fotovoltaicas, sendo que cada tipo de disposição acarreta diferentes níveis de eficiência do equipamento ${ }^{31}$.

Atualmente podemos encontrar três tipos diferentes de cristais de silício na confecção das células fotovoltaicas. Assim têm-se:

- silício monocristalino: é o tipo de célula de silício mais utilizada e comercializada, seu processo de fabricação é bem conhecido e estabelecido. Para a utilização do silício é necessário obter um alto grau de pureza, que é obtido através do "Processo Czochalski"32.

Em resumo, nesse processo vai-se extraindo um cilindro do material fundido, sendo que esse cilindro é depois cortado em fatias finas de aproximadamente $300 \mathrm{~mm}$, que formarão as células fotovoltaicas. Das células fotovoltaicas que utilizam o silício, as compostas de estrutura monocristalina são 
as que apresentam a melhor eficiência, variando de 12 a 18\%, porém são também as que demandam maior custo para a fabricação.

- silício policristalino: o processo de fabricação em si não varia muito, porém os controles em relação à pureza dos cristais obtidos são menores, diminuindo assim o custo final de fabricação desse tipo de célula. A eficiência é menor, sendo que o nível máximo obtido é de $12,5 \%{ }^{32}$.

- silício amorfo: nesse tipo de célula fotovoltaica os cristais de silício estão em grande desordem e em função disso o processo de fabricação não necessita ser muito apurado, tornando-se menos caro, fazendo com que o silício amorfo seja um grande concorrente no mercado de fabricação de células de baixo custo $^{33}$. Porém a eficiência também é afetada nesse sistema de cristalização do silício, surgindo ainda outro problema nesse processo, que é a degradação das células logo nos primeiros meses de operação, fazendo com que durante toda a vida útil da célula a eficiência seja reduzida ${ }^{33}$.

Outros materiais estão sendo testados para a confecção de células fotovoltaicas, com bons resultados na produção de energia. Porém devido à sua toxicidade estão encontrando alguma resistência quanto à sua utilização.

Atualmente estão em fase de teste o telureto de cádmio e o dissulfeto de cobre e índio. Além do aspecto da toxicidade é interessante lembrar que esses novos elementos na fabricação das células fotovoltaicas são muito mais raros e, portanto, mais caros que o silício, que é o segundo elemento mais abundante na superfície do planeta. A utilização de painéis de "filme fino" também vem sendo testada em alguns países com relativo sucesso na diminuição do custo desse componente $^{39}$. 


\section{Painel Fotovoltaico}

A construção básica de um painel fotovoltaico consiste de:

- entre 30 e 40 células fotovoltaicas normalmente de silício monocristalino, ligadas em série perfazendo normalmente $12 \mathrm{~V}$ de saída;

- caixa de material resistente, normalmente de aço com tratamento anti-corrosivo;

- material isolante para apoio das células, normalmente E.V.A

- vidro como superfície de contato com a luz solar, que deve ter características de grande resistência e ótima transparência;

- diodos de passo, conhecidos com "bypass", para evitar que uma célula encoberta ou com rendimento ruim prejudique o funcionamento do painel inteiro.

A estrutura básica de um painel fotovoltaico com os seus componentes é mostrada na FIG. 9

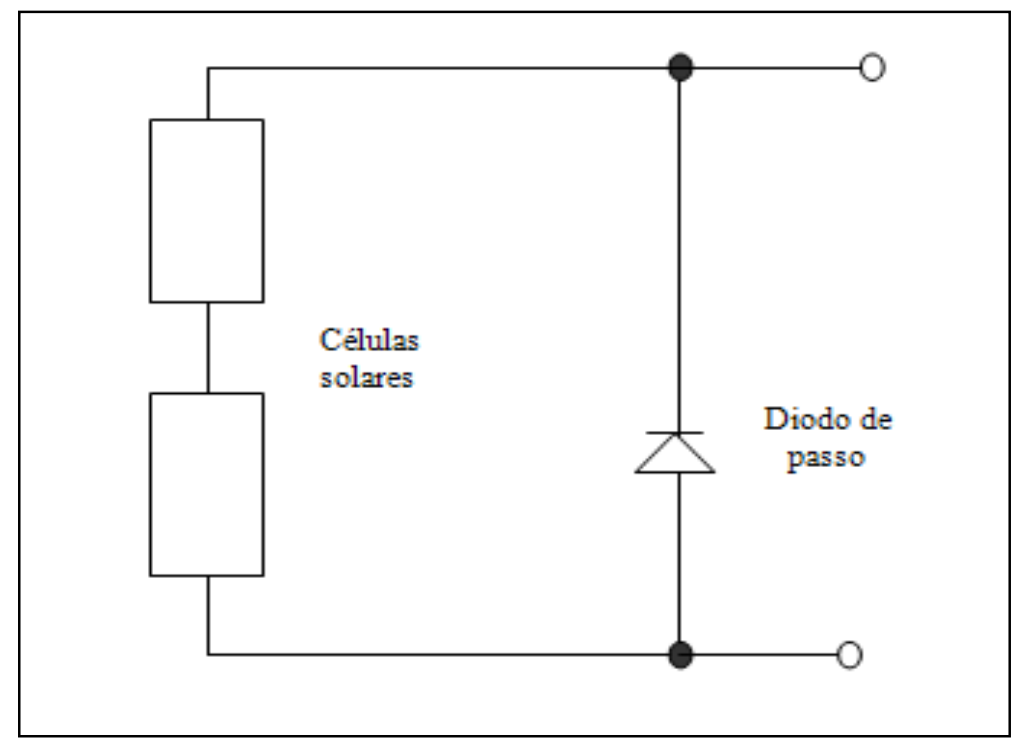

FIGURA 9: Sistema elétrico de um painel fotovoltaico.

A mais recente tecnologia aplicada à fabricação de painéis fotovoltaicos especialmente os de silício cristalino tem permitido uma melhora na eficiência dos mesmos, sendo que a média atualmente é de 13\% devendo chegar a $16 \%$ em $2011^{31}$. O Brasil apesar das diferenças climáticas apresenta um nível 
de radiação médio na atmosfera em torno de $5,4 \mathrm{KWh} / \mathrm{m}^{2} \cdot \mathrm{dia}^{34}$, mostrando boa uniformidade, sendo o valor máximo obtido no norte do estado da Bahia quase fronteira com o Piauí $\left(6,5 \mathrm{KWh} / \mathrm{m}^{2} \text {.dia }\right)^{35}$, e o valor mínimo no litoral norte de Santa Catarina $\left(4,25 \mathrm{KWh} / \mathrm{m}^{2} \text {.dia }\right)^{35}$, sendo que a quantidade de radiação global média que atinge cada região do Brasil pode ser vista na FIG. 10.

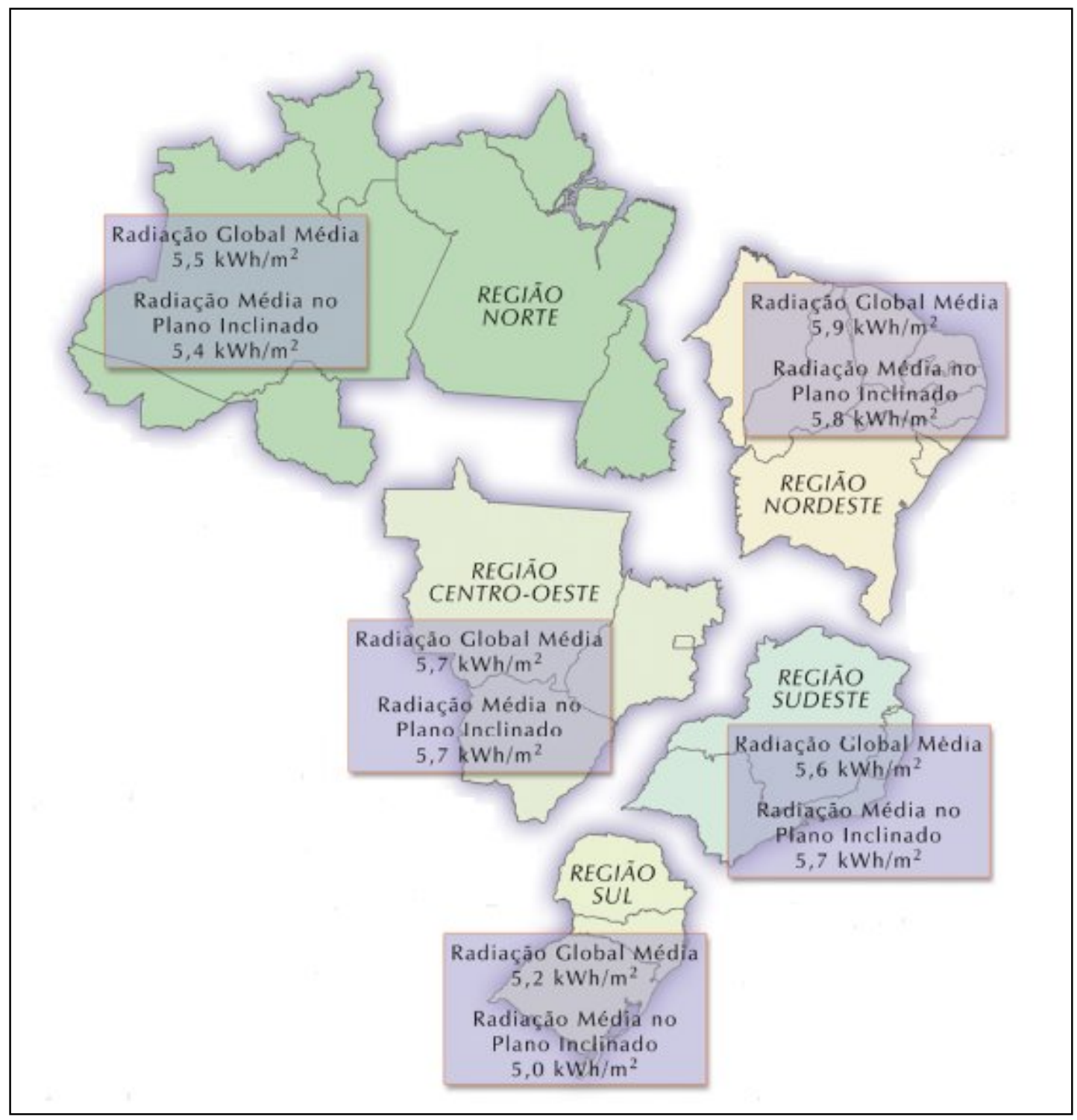

FIGURA 10: Radiação Global Média em cada uma das cinco regiões brasileiras $\left(\mathrm{Wh} / \mathrm{m}^{2} \cdot \mathrm{dia}\right)^{36}$.

Fica claro o grande potencial da energia solar no Brasil se levarmos em conta que nos países da União Européia onde vários projetos de aproveitamento 
da energia solar estão implantados ou em implantação, inclusive com recursos governamentais, as médias de radiação variam de 0,9 a $1,85 \mathrm{KWh} / \mathrm{m}^{2}$. dia ${ }^{37}$.

\subsubsection{Energia Hidroelétrica}

A estrutura básica de uma usina hidroelétrica é composta por uma barragem, sistema de captação e transporte de água, uma casa de força e um vertedouro. É essa barragem que vai estocar grandes quantidades de água, e inundar grandes áreas quando for necessário um reservatório para gerar um grande desnível. No caso das usinas de fio d'água a energia será gerada a partir da velocidade da água do rio e sendo assim não é necessário o alagamento de grandes áreas. A FIG. 11 mostra a estrutura de uma usina hidroelétrica em corte.

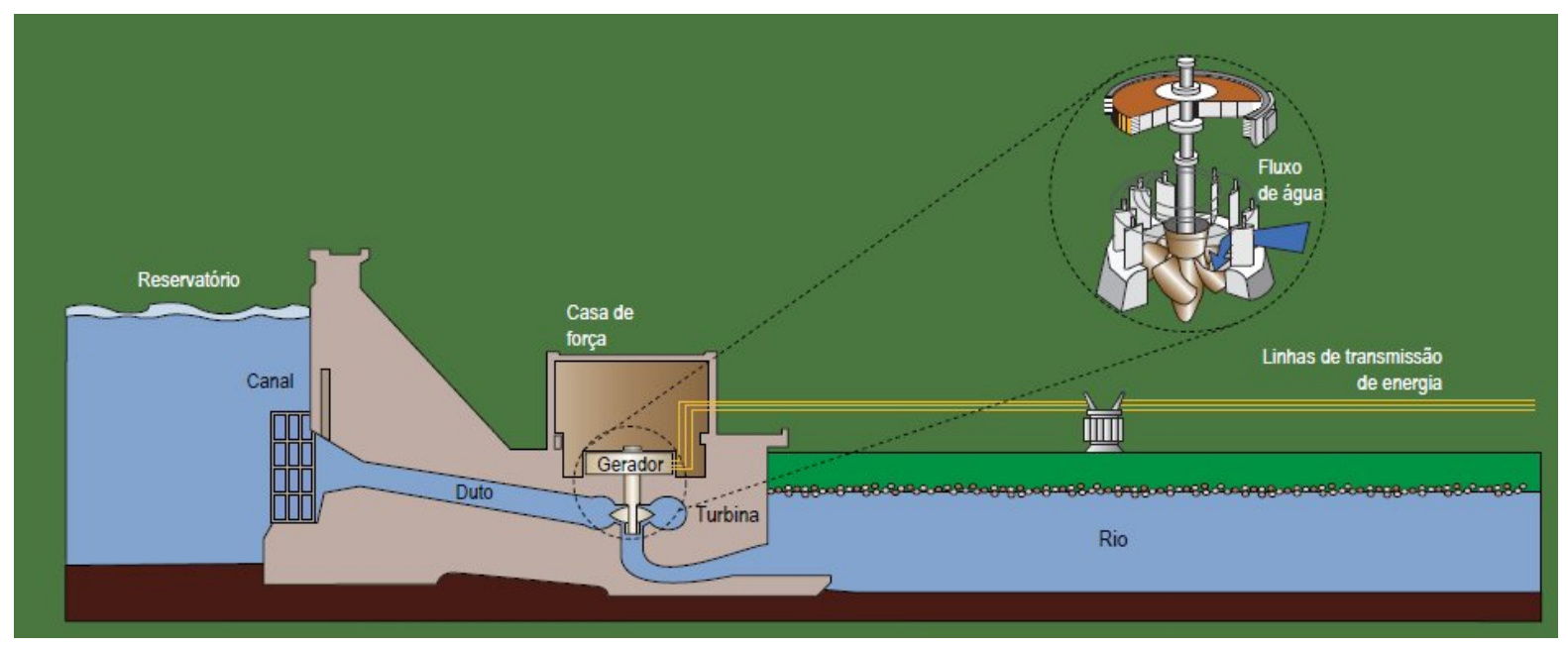

FIGURA 11: Vista em corte transversal de uma usina hidroelétrica ${ }^{10}$.

Apesar de seu cunho eminentemente renovável e de baixo impacto ambiental, vários estudos têm demonstrando que além da formação do lago com todas as conseqüências diretas da perda de terras produtivas e seus recursos naturais, ainda existe a liberação de gás metano no lago da usina em função da decomposição das plantas e outros organismos que acabam por ficar no fundo desse lago. Além, disso quando se trata de grandes empreendimentos estudos mostram que o clima regional pode sofrer alteração. 
O Brasil dispõe da maior reserva hidráulica superficial do planeta com cerca de $19 \%$ de toda a água, sendo que $84 \%$ da energia elétrica produzida no país provém dessa fonte. Para se produzir energia hidroelétrica, muitas variáveis devem ser combinadas tais como: desníveis de terreno, vazão do rio, quantidade de água disponível em determinadas épocas do ano e regularidade do regime de chuvas da região.

Além do que já foi dito outro ponto relevante deve ser levado em conta, os potenciais a serem explorados ainda em nosso país estão em regiões onde o impacto ambiental é grandemente aumentado por se tratar de região de mata Amazônica $^{40}$.

\subsubsection{Energia do Hidrogênio}

O hidrogênio é o primeiro elemento da tabela periódica, constituído apenas por um próton e um elétron, sendo o elemento mais simples de todo universo e um dos mais abundantes. Só é possível encontrá-lo associado a outros elementos.

No seu estado natural e sob condições ambientes de temperatura e pressão, o hidrogênio é um gás incolor, inodoro, insípido e muito mais leve que o ar. Ele também pode estar no estado líquido, ocupando um espaço 700 vezes menor do que se estivesse em forma de gás. Mas ele tem que estar armazenado numa temperatura de $-253^{\circ} \mathrm{C}$, em sistemas de armazenamento conhecidos como "sistemas criogênicos". Acima desta temperatura, o hidrogênio não pode ser liquefeito, mas pode ser armazenado em forma de gás comprimido em cilindros de alta pressão.

Atualmente, a maior parte do hidrogênio produzido no mundo é utilizada como matéria-prima na fabricação de produtos como os fertilizantes, na conversão de óleo líquido em margarina, no processo de fabricação de plásticos e no resfriamento de geradores e motores. Atualmente, as pesquisas sobre hidrogênio estão concentradas na geração de energia elétrica por meio das células a combustível.

O hidrogênio é anunciado por vários pesquisadores nas mais diversas áreas, que vão da economia à física como sendo a grande oportunidade de 
abastecimento crescente de energia com baixo impacto ambiental. O hidrogênio apresenta-se sempre ligado a algum outro elemento químico apresentando alguns desafios para a sua produção e futuro aproveitamento, porém as circunstâncias estão conduzindo um movimento global de estudos e pesquisas para o seu aproveitamento, tendo como fontes as mais variadas possíveis.

Centrais de geração de energia elétrica com a utilização de células a combustível tendo como fonte o hidrogênio puro (eletrólise, por exemplo), ou ligado a outros elementos (gás de síntese, biogás, gás natural etc.) já estão previstas em várias regiões do planeta. Países como USA através de seus órgãos governamentais já planejam e pesquisam sistemas de produção localizada ou distribuída de hidrogênio com finalidade veicular, já que grande parte de suas emissões é produzida pelos veículos.

Por tudo isso não é de se surpreender que o termo "Economia do Hidrogênio" tenha se fixado junto ao meio acadêmico e à imprensa como uma possibilidade de abastecimento energético real para as futuras gerações $^{41,42,43,44,45,46,47,48,49,50,51,52}$.

Para utilização do hidrogênio como fonte de energia é necessário o seu uso junto a uma célula a combustível.

\subsubsection{1 - Células a combustível}

A célula a combustível é uma célula eletroquímica que converte continuamente a energia química de um combustível como, por exemplo, hidrogênio, em energia elétrica, usando o oxigênio como oxidante, gerando água e calor. Ao contrário das baterias eletroquímicas, a energia química é armazenada fora da célula combustível onde ocorre a reação.

Uma vez que o combustível (hidrogênio) é convertido diretamente em eletricidade, a célula a combustível pode operar com eficiência muito maior do que motores de combustão interna (sob o ciclo de Carnot a altas temperaturas), extraindo mais eletricidade da mesma quantidade de combustível $^{53}$. Outra vantagem é o fato da célula a combustível não possuir partes móveis, o que a torna muito mais silenciosa e confiável, além de poder trabalhar com diferentes combustíveis $^{53}$. 
Teoricamente qualquer substância capaz de sofrer oxidação, que possa ser fornecida continuamente na forma de fluído, pode ser queimada galvanicamente como combustível no ânodo de uma célula a combustível. De maneira similar o oxidante pode ser qualquer fluído capaz de sofrer redução em velocidade adequada ${ }^{54}$.

O hidrogênio foi o combustível escolhido para a maior parte das aplicações devido sua alta reatividade, quando escolhido o catalisador adequado, e sua facilidade de obtenção também a partir de hidrocarbonetos. O oxidante mais comumente utilizado é o oxigênio que é facilmente encontrado no ar atmosférico ${ }^{54}$.

Como a célula a combustível funciona alimentada por hidrogênio e oxigênio, que ao final se recombinam para formar água, o sistema não gera gases de efeito estufa, como o gás carbônico. Além disso, ao contrário do que ocorre em processos de queima de combustíveis fósseis, não há a emissão de monóxido de carbono, óxidos de enxofre, hidrocarbonetos, material particulado, etc. para a atmosfera.

Uma célula individual tipo membrana é composta por dois eletrodos porosos (catodo e anodo), impregnados com catalisadores que promovem a ionização em cada lado da membrana de troca iônica. Estes componentes são montados em unidades chamadas MEA como mostra a FIG. 12 
A célula tem dois compartimentos separados por uma membrana que só permite a passagem de prótons. (Átomos de hidrogênio sem elétrons, $\mathrm{H}^{+}$)

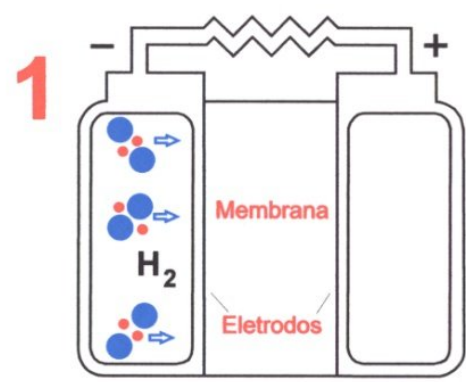

O hidrogênio $\left(\mathrm{H}_{2}\right)$ entra por um lado da célula.

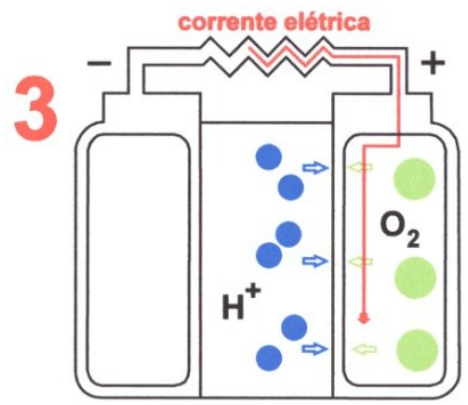

Outro eletrodo atrai os prótons que estão na membrana. $O$ oxigênio $\left(\mathrm{O}_{2}\right)$ entra pelo outro lado.

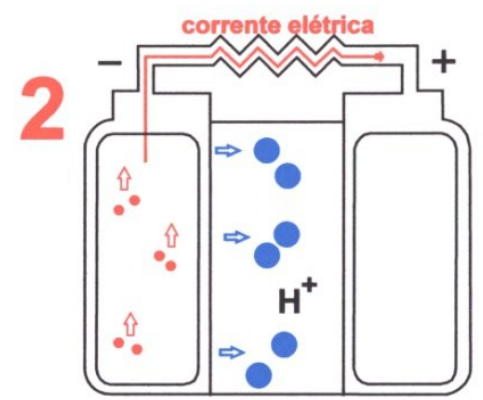

Um eletrodo faz com que os elétrons se desprendam dos átomos de hidrogênio gerando corrente elétrica. Os prótons desacompanhados atravessam a membrana.

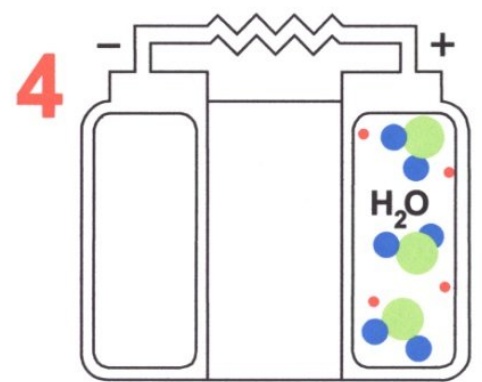

Ocorre uma reação simultânea entre $\mathrm{H}^{+}$, elétrons e oxigênio $\left(\mathrm{O}_{2}\right)$ formando água $\left(\mathrm{H}_{2} \mathrm{O}\right)$.

FIGURA 12: Funcionamento da célula a combustível ${ }^{55}$.

A interface entre os reagentes, eletrólito e catalisador na região do eletrodo poroso é um ponto crítico na eficiência da célula a combustível, particularmente nas células com eletrólitos líquidos. No tipo de célula de membrana o gás se difunde através de um fino filme de eletrólito que está em contato com o eletrodo poroso, e reage eletroquimicamente na superfície do eletrodo. Se existe uma quantidade excessiva de eletrólito o transporte de gases até a superfície do eletrodo sofre restrição e diminui o desempenho do eletrodo.

\section{Eletrodos}

A principal função do eletrodo é fornecer uma superfície onde irão ocorrer as reações de oxidação/redução.

De modo a aumentar as velocidades de reação o material do eletrodo precisa ser um bom catalisador e um bom condutor elétrico. 
A função catalítica do eletrodo é mais importante em células que funcionam a baixa temperatura.

Membrana/Eletrólito

As características ideais são:

- conduzir os íons à medida que estes se formam;

- formar uma barreira física que separe os reservatórios de gases do eletrólito.

-boa condutividade protônica;

- bom isolamento eletrônico;

- não necessitar de umidificação;

-boa durabilidade e neutralidade química;

-resistência mecânica suportando variações de pressão;

- baixo custo;

- ser flexível para operar a temperaturas mais altas, possibilitando o uso de outros catalisadores, melhorando a eficiência do gerenciamento térmico, da umidificação e da contaminação por monóxido de carbono ${ }^{53}$.

A função do eletrólito é transportar os reagentes dissolvidos até os eletrodos, conduzir as cargas iônicas aos eletrodos completando o circuito elétrico além de ser uma barreira física que limita o contato entre o combustível e o oxidante.

Eletrólitos aquosos estão limitados a temperaturas de cerca de $200{ }^{\circ} \mathrm{C}$ ou inferiores, devido à sua alta pressão de vapor e/ou sua rápida degradação a altas temperaturas.

A temperatura de operação da célula também determina o tipo de combustível que pode ser utilizado. Em células que operam a altas temperaturas o $\mathrm{CO}$ ou até mesmo o $\mathrm{CH}_{4}$ podem ser utilizados como combustível ${ }^{53}$.

O conjunto

A energia elétrica do sistema é determinada pela quantidade de células e pela suas respectivas áreas. A quantidade de energia requerida pelas aplicações determinará as dimensões do conjunto. 
As células individuais precisam ser combinadas para produzir níveis de voltagem apreciáveis e são ligadas por interconectores, que são placas separadoras com duas funções, a saber: formar conexões elétricas entre células adjacentes, fornecer uma barreira separando o combustível do oxidante em células adjacentes ${ }^{55}$.

As características ideais das placas são:

-boa condutividade eletrônica e térmica;

- impermeabilidade a hidrogênio, oxigênio/ar e água;

-resistência mecânica para suportar compactação;

- neutralidade química;

- baixo custo;

- resistência à temperatura de operação da célula;

- pouca espessura, possibilitando canais de fluxo gasoso de ambos os lados;

- minimizar a perda de carga dos gases;

- compatibilidade com as juntas de vedação inseridas nas placas ${ }^{53}$.

Quando o oxigênio do ar é utilizado como oxidante a produção de energia é otimizada com o fornecimento de ar sob pressão. É então acoplado ao conjunto um compressor que fornecerá ar comprimido. O ar externo é então encaminhado a um filtro, comprimido e fornecido às células. Este mesmo ar auxiliará na retirada da água produzida pela célula.

Hidrogênio gasoso pode ser também armazenado em cilindros pressurizados. O fornecimento do combustível é uma operação simples. Esse combustível então é conduzido à célula, sem qualquer necessidade de energia externa.

A água proveniente do sistema de resfriamento é utilizada para umidificar o ar e o gás afluente à célula. Um sistema auxiliar de resfriamento é utilizado na manutenção da temperatura dos componentes elétricos e dos condensadores de ar, em níveis adequados. 


\subsection{Tipos de células a combustível}

Existe uma série de tipos de células a combustível em vários estágios de desenvolvimento. A forma mais comum de classificação das células a combustível é pelo tipo de eletrólito utilizado.

$\mathrm{Na}$ TAB. 2 são apresentados os tipos de células a combustível existentes, assim como suas principais características. Deve-se destacar que as abreviações utilizadas para designar as células estão baseadas em siglas em inglês que são internacionalmente utilizadas.

TABELA 2: Características das células a combustível ${ }^{56}$.

\begin{tabular}{|c|c|c|c|c|c|c|c|}
\hline $\begin{array}{c}\text { Tipo de } \\
\text { Célula } \\
\text { Combustível }\end{array}$ & Portador \\
de carga & Eletrólito & $\begin{array}{c}\text { Direção } \\
\text { do fluxo } \\
\text { de carga }\end{array}$ & Combustível & Catalisador & $\begin{array}{c}\text { Eficiência } \\
\text { Nominal } \\
\text { do } \\
\text { Sistema } \\
(\%)\end{array}$ & $\begin{array}{c}\text { Temp. } \\
\left({ }^{\circ} \mathrm{C}\right)\end{array}$ \\
\hline $\begin{array}{c}\text { Alcalina } \\
\text { (AFC) }\end{array}$ & $\mathrm{OH}^{-}$ & $\begin{array}{c}\mathrm{KOH} \\
\text { Diluído }\end{array}$ & $\begin{array}{c}\text { Cátodo- } \\
\text { Anodo }\end{array}$ & $\mathrm{H}_{2}$ & $\mathrm{Pt} / \mathrm{Ni} / \mathrm{Ag}$ & $55-60$ & $70-250$ \\
\hline $\begin{array}{c}\text { Membrana de } \\
\text { troca de } \\
\text { Prótons } \\
\text { (PEMFC) }\end{array}$ & $\mathrm{H}^{+}$ & $\begin{array}{c}\text { Cloro } \\
\text { Álcali } \\
\text { Polímeros } \\
\mathrm{e} \\
\text { Sulfonatos }\end{array}$ & $\begin{array}{c}\text { Anodo - } \\
\text { Cátodo }\end{array}$ & $\begin{array}{c}\mathrm{H}_{2} \\
\text { Reformado }\end{array}$ & $\mathrm{Pt} / \mathrm{Ru}$ & $32-40$ & $70-90$ \\
\hline $\begin{array}{c}\text { Metanol } \\
\text { Direto } \\
\text { (DMFC) }\end{array}$ & $\mathrm{H}^{+}$ & $\begin{array}{c}\text { Membrana } \\
\text { Polimérica }\end{array}$ & $\begin{array}{c}\text { Anodo - } \\
\text { Cátodo }\end{array}$ & $\mathrm{CH}_{3} \mathrm{OH}$ & $\mathrm{Pt} / \mathrm{Ru}$ & $35-40$ & $50-100$ \\
\hline $\begin{array}{c}\text { Ácido } \\
\text { Fosfórico } \\
\text { (PAFC) }\end{array}$ & $\mathrm{H}^{+}$ & $\begin{array}{c}\text { Ácido } \\
\text { Fosfórico }\end{array}$ & $\begin{array}{c}\text { Anodo - } \\
\text { Cátodo }\end{array}$ & $\mathrm{GN}$ & $\mathrm{Pt}$ & $36-45$ & $150-220$ \\
\hline $\begin{array}{c}\text { Carbonato } \\
\text { Fundido } \\
\text { (MCFC) }\end{array}$ & $\mathrm{CO}_{3}{ }^{-2}$ & $\begin{array}{c}\text { Carbonato } \\
\text { Líquido }\end{array}$ & $\begin{array}{c}\text { Cátodo - } \\
\text { Anodo }\end{array}$ & $\mathrm{GN}$ & - & $50-60$ & $550-700$ \\
\hline $\begin{array}{c}\text { Óxido Sólido } \\
\text { ( SOFC) }\end{array}$ & $\mathrm{O}^{-2}$ & $\begin{array}{c}\text { Dióxido de } \\
\text { Zircônio } \\
\text { Sólido }\end{array}$ & $\begin{array}{c}\text { Cátodo - } \\
\text { Anodo }\end{array}$ & $\mathrm{GN}$ & - & $5-60$ & $650-1100$ \\
\hline
\end{tabular}


A seguir são descritos de maneira resumida os principais tipos de célula a combustível:

\subsection{Célula Alcalina - AFC}

Longamente utilizada pela NASA em missões espaciais, este tipo de célula pode atingir eficiência de geração de energia entre 55 e $60 \%{ }^{46}$. Ela foi utilizada na espaçonave Apolo e no ônibus espacial para fornecer energia e água.

O eletrólito utilizado nesta célula é uma solução de $85 \%$ em peso de $\mathrm{KOH}$, quando a célula opera a $250^{\circ} \mathrm{C}$, ou $30-50 \%$ de $\mathrm{KOH}$ se a temperatura de operação for inferior a $120^{\circ} \mathrm{C}$. O eletrólito é usualmente retido numa matriz de asbestos. A reação do cátodo é mais rápida em solução alcalina, o que aumenta a eficiência da célula. Uma grande série de eletrocatalisadores pode ser utilizada como $\mathrm{Ni}$, Ag, óxidos metálicos, etc. O CO provoca o "envenenamento do catalisador" e o $\mathrm{CO}_{2}$ reage com o $\mathrm{KOH}$ formando $\mathrm{K}_{2} \mathrm{CO}_{3}$ e alterando a composição do eletrólito ${ }^{57}$.

As reações que ocorrem na célula são:

$$
\begin{aligned}
& \text { Ânodo: } \mathrm{H}_{2}+2 \mathrm{OH}^{-} \rightarrow 2 \mathrm{H}_{2} \mathrm{O}+2 \mathrm{e}^{-} \\
& \text {Cátodo: } 1 / 2 \mathrm{O}_{2}+\mathrm{H}_{2} \mathrm{O}+2 \mathrm{e}^{-} \rightarrow 2 \mathrm{OH}^{-} \\
& \text {Célula : } \mathrm{H}_{2}+1 / 2 \mathrm{O}_{2} \rightarrow \mathrm{H}_{2} \mathrm{O}
\end{aligned}
$$

Até recentemente este tipo de célula era muito caro para aplicações comerciais, porém, estão sendo examinados meios de reduzir custos. Existem células de $300 \mathrm{~W}$ a $5 \mathrm{~kW}^{57}$. A estrutura interna desse tipo de célula pode ser vista na FIG. 1 


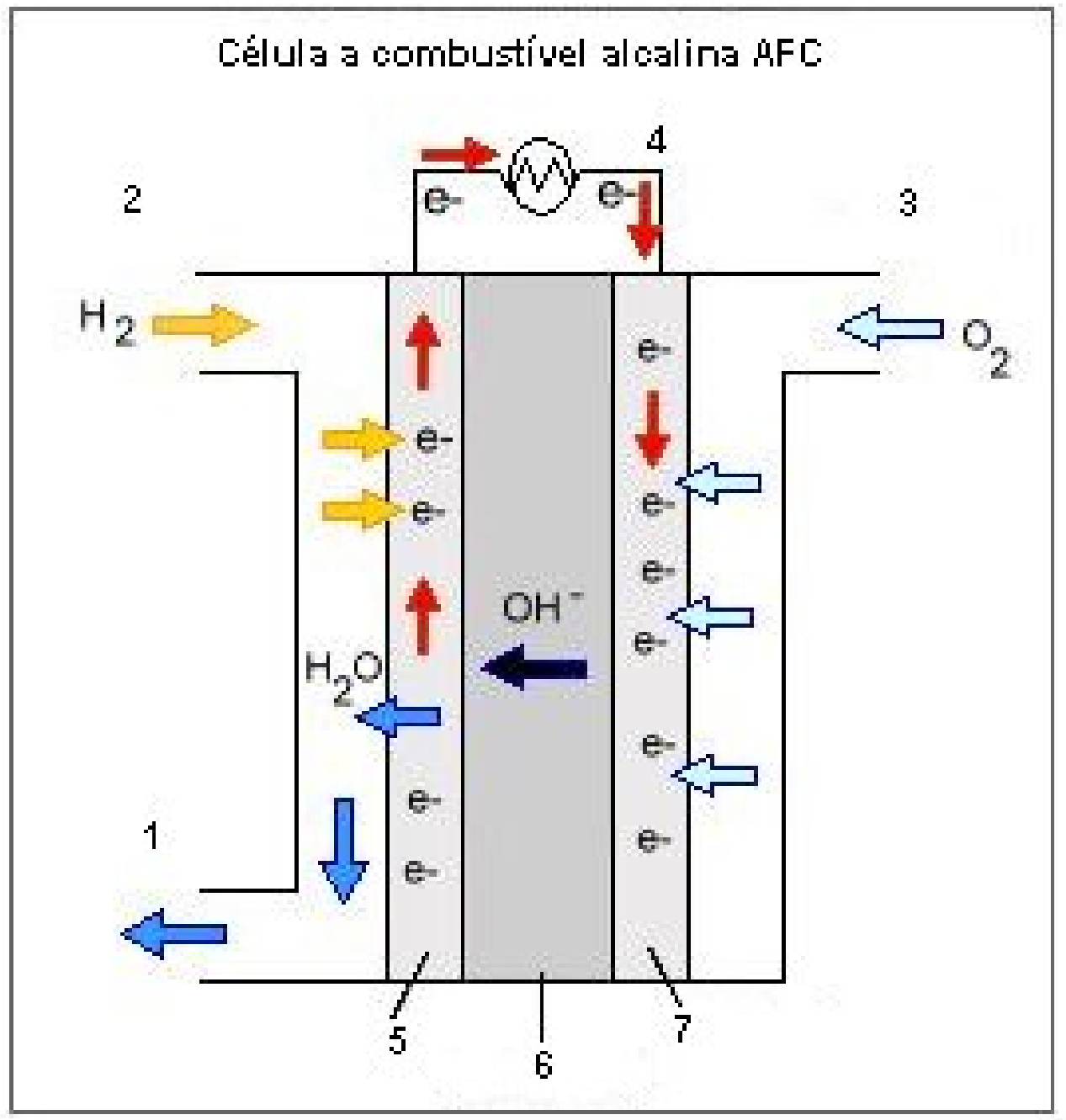

FIGURA 13: Célula a combustível alcalina (AFC).

1-Saída de água e calor.

2-Entrada de combustível.

3-Entrada de oxigênio.

4- Corrente elétrica.

5-Anodo.

6-Eletrólito.

7-Catodo. 


\subsection{Célula de membrana de troca de prótons - PEMFC}

Este tipo de célula opera geralmente a temperaturas relativamente baixas, cerca de $80^{\circ} \mathrm{C}$ e é aconselhável para uso em automóveis onde uma partida rápida é necessária.

A membrana/eletrólito de troca de prótons é uma membrana plástica que permite a passagem de íons de hidrogênio. Esta membrana é coberta em ambos os lados por partículas metálicas finamente divididas, principalmente Pt, que agem como catalisador. A membrana/eletrólito é um polímero orgânico sólido, geralmente ácido poli-perfluorosulfônico.

A vantagem de um eletrólito sólido é que ele diminui os problemas de corrosão. Este tipo de célula é muito sensível a impurezas no combustível ${ }^{57}$.

As reações químicas que ocorrem na célula são:

$$
\begin{aligned}
& \text { Ânodo: } \mathrm{H}_{2} \rightarrow 2 \mathrm{H}^{+}+2 \mathrm{e}^{-} \\
& \text {Cátodo: } 1 / 2 \mathrm{O}_{2}+2 \mathrm{H}^{+}+2 \mathrm{e}^{-} \rightarrow \mathrm{H}_{2} \mathrm{O}^{-} \\
& \text {Célula: } \mathrm{H}_{2}+1 / 2 \mathrm{O}_{2} \rightarrow \mathrm{H}_{2} \mathrm{O}
\end{aligned}
$$

A estrutura interna desse tipo de célula pode ser vista na FIG. 14 
Célula a Combustivel do Tipo FEM

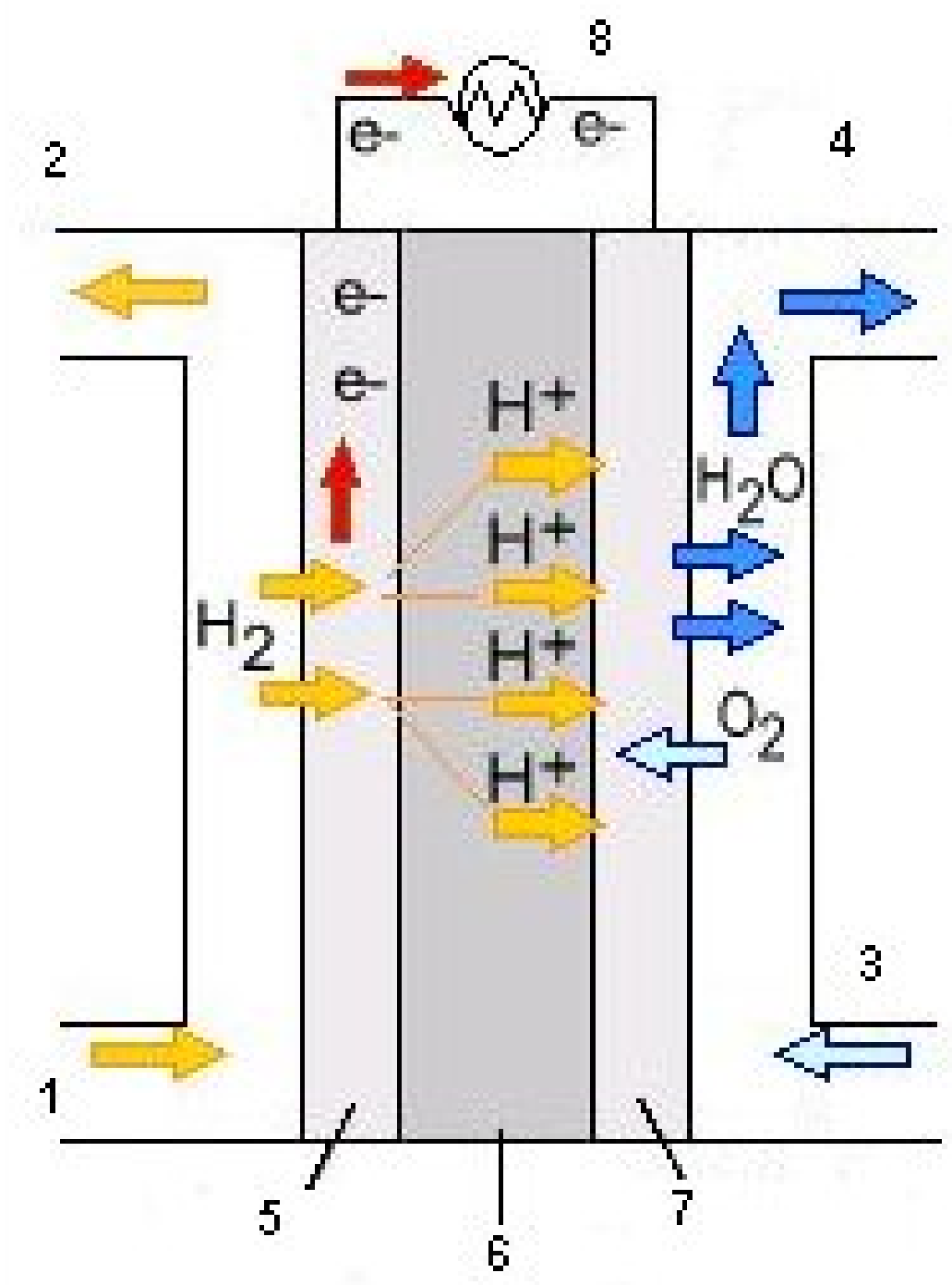

FIGURA 14: Célula a combustível de membrana (PEM).

1-Entrada de combustível.

2-Saída de excesso de combustível.

3-Entrada de ar.

4-Saída de água e calor.

5-Anodo.

6-Eletrólito.

7-Catodo.

8-Corrente elétrica. 


\subsection{Célula a metanol direto - DMFC}

Este tipo de célula é similar à célula de membrana de troca de prótons pelo fato de ambas utilizarem uma membrana polimérica como eletrólito. Neste caso $\circ \mathrm{H}^{+}$é formado diretamente no ânodo eliminando a necessidade de reforma externa de combustível. A eficiência esperada é de cerca de $40 \%$ e a célula opera a temperaturas típicas de 50 a $100{ }^{\circ} \mathrm{C}$. É adequada para pequenas aplicações como fornecer energia elétrica para celulares e laptops ${ }^{58}$.

As reações que ocorrem na célula são:

$$
\begin{aligned}
& \text { Ânodo: } \mathrm{CH}_{3} \mathrm{OH}+\mathrm{H}_{2} \mathrm{O} \rightarrow \mathrm{CO}_{2}+6 \mathrm{H}^{+}+6 \mathrm{e}^{-} \\
& \text {Cátodo: } 3 / 2 \mathrm{O}_{2}+6 \mathrm{H}^{+}+6 \mathrm{e}^{-} \rightarrow 3 \mathrm{H}_{2} \mathrm{O} \\
& \text { Célula: } \mathrm{CH}_{3} \mathrm{OH}+3 / 2 \mathrm{O}_{2} \rightarrow \mathrm{CO}_{2}+3 \mathrm{H}_{2} \mathrm{O}
\end{aligned}
$$

A célula alimentada por metanol apresenta um esquema de funcionamento semelhante as alimentadas por hidrogênio puro e são pesquisadas há poucos anos, sendo portanto uma tecnologia relativamente nova ${ }^{59}$.

\subsection{Célula de Ácido Fosfórico - PAFC}

Este tipo de célula opera de 150 a $220^{\circ} \mathrm{C}$. A baixas temperaturas, 0 ácido fosfórico é um condutor iônico fraco e o CO "envenena" o catalisador de Pt de maneira severa. A alta estabilidade relativa do ácido fosfórico em comparação com outros ácidos faz com que se possa trabalhar com o ácido a temperaturas entre 100 e $200^{\circ} \mathrm{C}$. Em adição, o uso do ácido concentrado minimiza a pressão de vapor da água, fazendo com que não seja difícil a manutenção dos níveis de água na célula. A matriz que vem sendo utilizada para retenção do ácido é o carbeto de silício e o eletrocatalisador, tanto do cátodo como do ânodo, é a $\mathrm{Pt}^{57}$.

Uma das grandes vantagens deste tipo de célula é que hidrogênio impuro pode ser utilizado como combustível, pois em função da temperatura o CO não inativa o catalizador. 
Este tipo de célula pode tolerar concentrações de CO de até 1,5\%, o que aumenta os tipos de combustíveis usados.

Como desvantagens podem-se citar a geração de baixa corrente, quando comparada com outros tipos de células e, geralmente, seu alto peso e tamanho. Este tipo de célula possui longa vida útil.

As reações que ocorrem na célula são:

$$
\begin{aligned}
& \text { Ânodo: } \mathrm{H}_{2} \rightarrow 2 \mathrm{H}^{+}+2 \mathrm{e}^{-} \\
& \text {Cátodo: } 1 / 2 \mathrm{O}_{2}+\mathrm{H}^{+}+2 \mathrm{e}^{-} \rightarrow \mathrm{H}_{2} \mathrm{O} \\
& \text { Célula: } \mathrm{H}_{2}+1 / 2 \mathrm{O}_{2}+\mathrm{CO}_{2} \rightarrow \mathrm{H}_{2} \mathrm{O}+\mathrm{CO}_{2}
\end{aligned}
$$

Este tipo de célula está disponível comercialmente, existindo no mundo mais de 200 sistemas instalados em hospitais, hotéis, escritórios, aeroportos, etc ${ }^{57}$. No Brasil já existem quatro sistemas "no break" de porte utilizando este tipo de célula.

A estrutura interna desse tipo de célula pode ser vista na FIG. 15. 


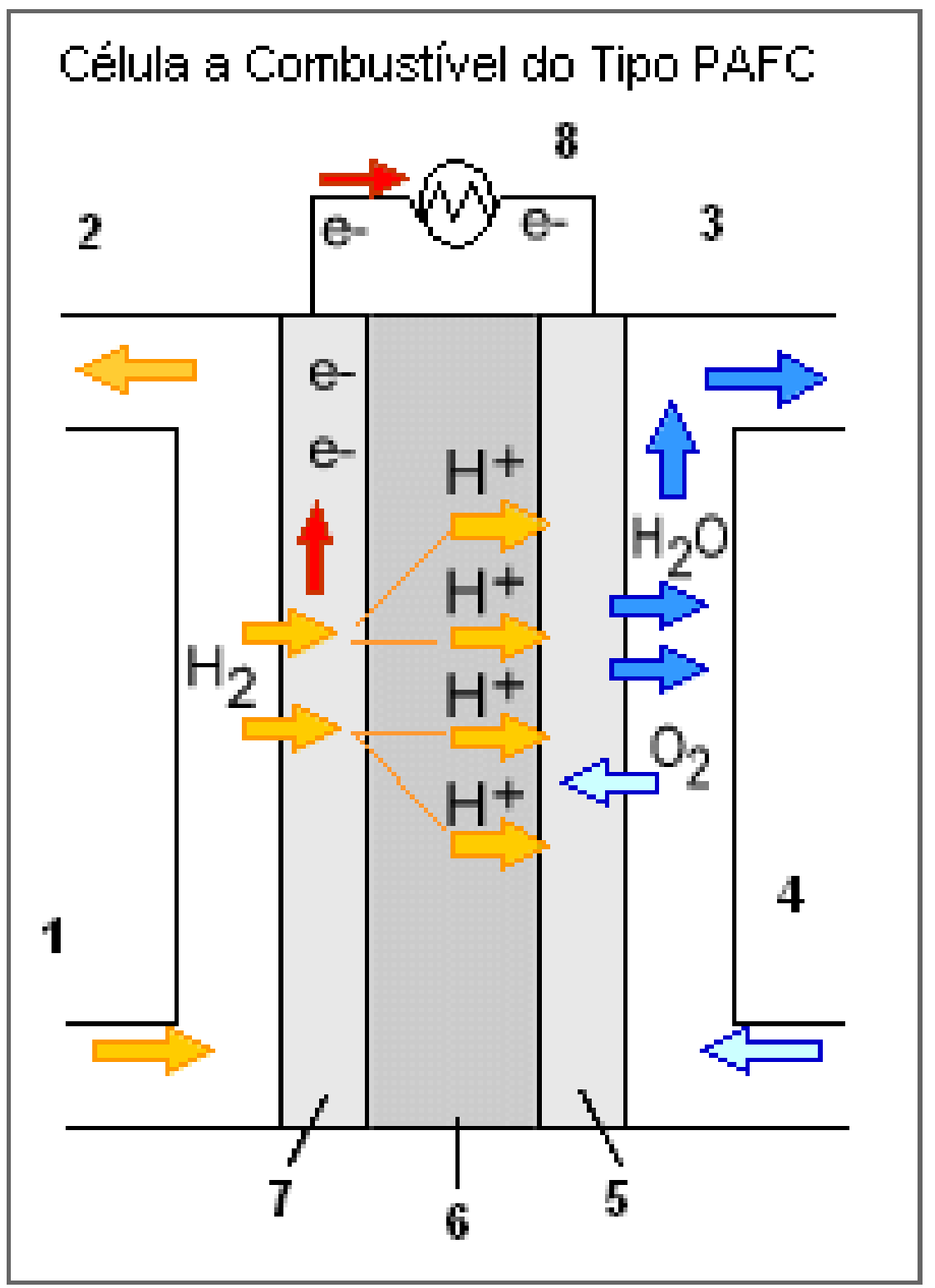

FIGURA 15: Célula a combustível de ácido fosfórico (PAFC).

1-Entrada de combustível.

2-Saída de excesso de combustível.

3-Saída de água e calor.

4-Entrada de ar.

5-Catodo.

6-Eletrólito.

7-Anodo.

8-Corrente elétrica. 


\subsection{Célula de carbonato fundido - MCFC}

O eletrólito deste tipo de célula é uma solução de carbonatos de Li, $\mathrm{Na}$ e/ou $\mathrm{K}$ retido em uma matriz cerâmica de $\mathrm{LiAlO}_{2}$, sendo a eficiência deste tipo de célula de cerca de $60 \%{ }^{57}$.

A célula opera a uma temperatura entre 550 e $700{ }^{\circ} \mathrm{C}$. A alta temperatura é necessária para que o eletrólito tenha condutividade suficiente. Devido à alta temperatura, não são necessários metais nobres para catalisar os processos de oxi-redução. As altas temperaturas de operação são vantajosas uma vez que implicam em altas eficiências, maior flexibilidade no tipo de combustível e catalisadores baratos, já que as reações envolvendo a quebra das ligações de hidrocarbonetos de maior peso molecular ocorrem mais rapidamente com o aumento da temperatura.

A desvantagem é que altas temperaturas aumentam os processos de corrosão (46) Geralmente o ânodo é de Ni e o cátodo de óxido de níquel ${ }^{55}$.

Este tipo de célula pode ser operada com hidrogênio, monóxido de carbono, gás natural, propano, gás proveniente de aterros, etc. Células com potência variando ente $10 \mathrm{~kW}$ e $2 \mathrm{MW}$ foram testadas principalmente para geração de energia estacionária ${ }^{55,56,57}$.

As reações que ocorrem na célula são:

$$
\begin{aligned}
& \text { Ânodo: } \mathrm{H}_{2}+\mathrm{CO}_{3}^{-2} \rightarrow \mathrm{H}_{2} \mathrm{O}+\mathrm{CO}_{2}+2 \mathrm{e}^{-} \\
& \text {Cátodo: } 1 / 2 \mathrm{O}_{2}+\mathrm{CO}_{2}+2 \mathrm{e}^{-} \rightarrow \mathrm{CO}_{3}^{-2} \\
& \text { Célula: } \mathrm{H}_{2}+1 / 2 \mathrm{O}_{2}+\mathrm{CO}_{2} \rightarrow \mathrm{H}_{2} \mathrm{O}+\mathrm{CO}_{2}
\end{aligned}
$$

A estrutura interna desse tipo de célula pode ser vista na FIG. 16. 


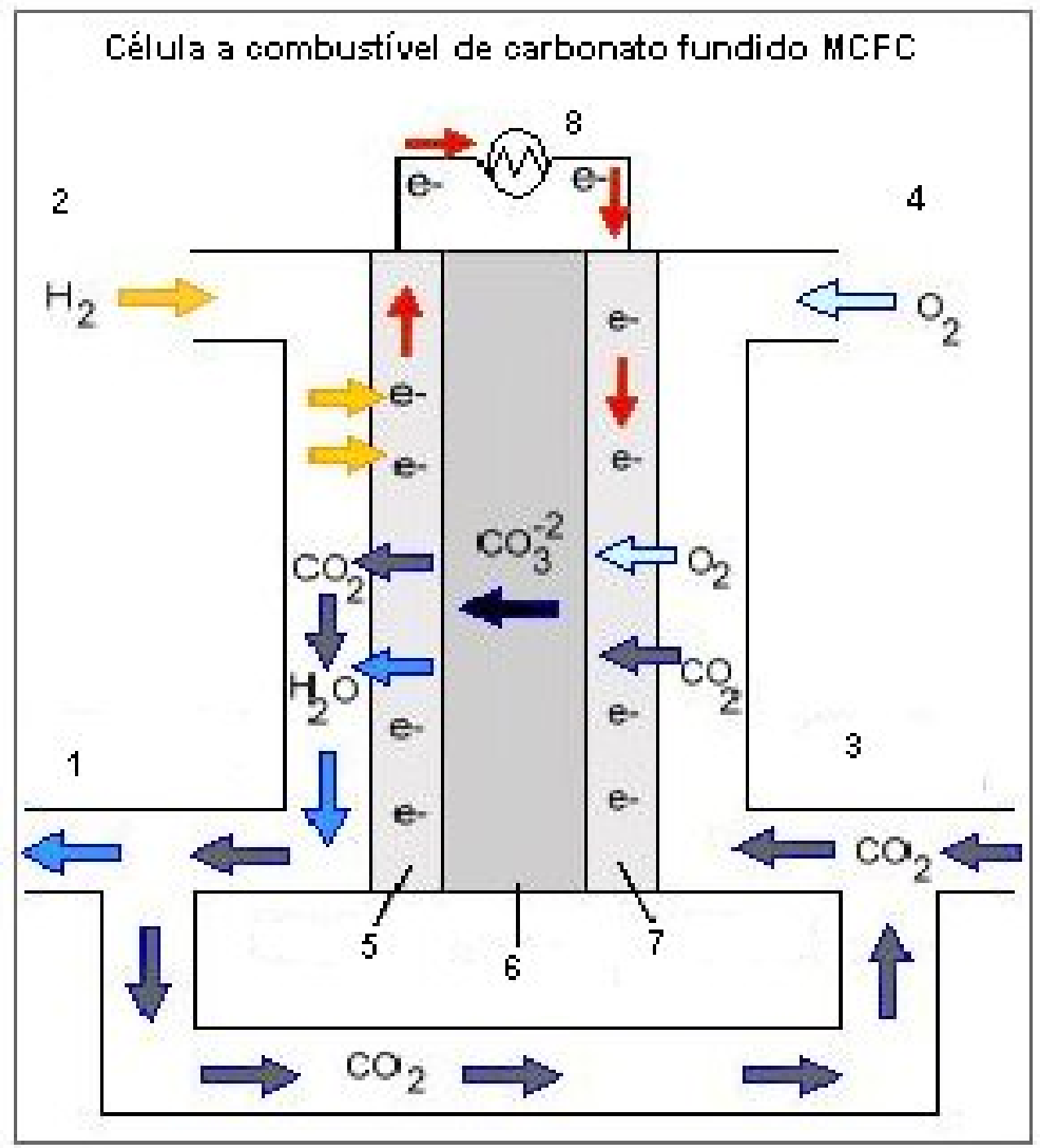

FIGURA 16: Célula de eletrólito fundido.

1- Saída de água e calor.

2- Entrada de combustível.

3-Entrada de dióxido de carbono.

4-Entrada de oxigênio.

5-Ânodo.

6-Eletrólito.

7-Cátodo.

8-Corrente elétrica. 


\subsection{Célula de óxido sólido - SOFC}

$\mathrm{O}$ eletrólito deste tipo de célula é um óxido metálico, geralmente $\mathrm{ZrO}_{2}$ estabilizado com $\mathrm{Y}_{2} \mathrm{O}_{3}$, o que permite que a célula opere a temperaturas de 650 a $1000^{\circ} \mathrm{C}$ quando ocorre a condução iônica através de íons de oxigênio ${ }^{57}$.

A eficiência deste tipo de célula chega a $60 \%$, sendo uma tecnologia promissora para o uso em grandes sistemas de geração de energia.

As reações que ocorrem nas células são:

Ânodo: $\mathrm{H}_{2}+\mathrm{O}^{2-} \rightarrow \mathrm{H}_{2} \mathrm{O}+2 \mathrm{e}^{-}$

Cátodo: $1 / 2 \mathrm{O}_{2}+2 \mathrm{e}^{-} \rightarrow \mathrm{O}^{2-}$

Célula : $\mathrm{H}_{2}+1 / 2 \mathrm{O}_{2} \rightarrow \mathrm{H}_{2} \mathrm{O}$

A estrutura interna desse tipo de célula pode ser vista na FIG. 17. 


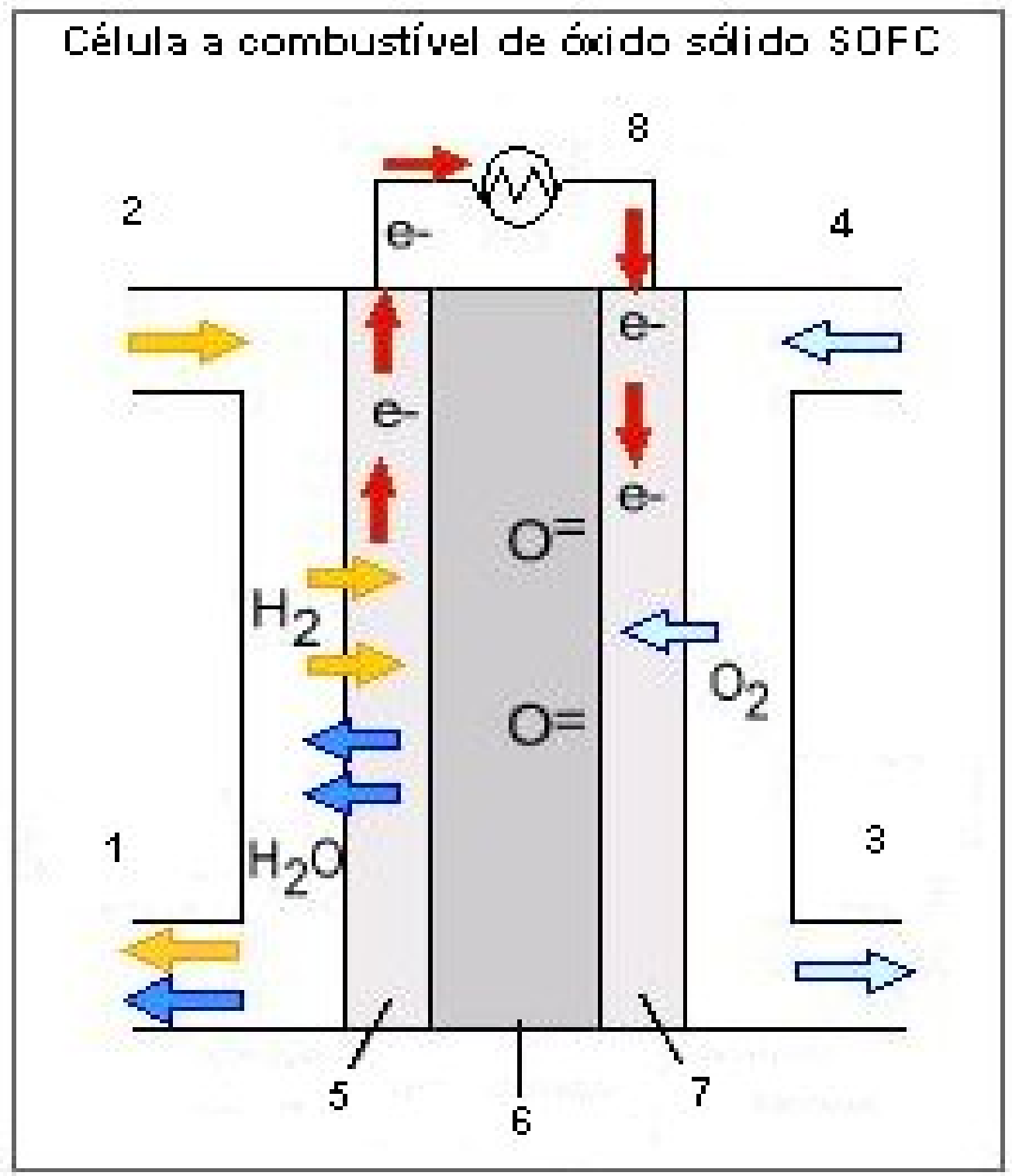

FIGURA 17: Célula de eletrólito fundido

1- Saída de excesso de combustível e água.

2- Entrada de combustível.

3- Saída de oxigênio não usado.

4-Entrada de oxigênio.

5-Ânodo.

6-Eletrólito.

7-Cátodo.

8-Corrente elétrica.

A seguir são apresentados alguns tipos de célula a combustível que ainda estão em fase inicial de desenvolvimento: 


\subsection{Células a combustível regenerativas.}

Ainda em desenvolvimento, este tipo de célula pode ser atrativo por produzir um ciclo fechado de geração de energia. A água é transformada em hidrogênio e oxigênio por um eletrolisador movido a energia solar. O hidrogênio e o oxigênio alimentam a célula gerando eletricidade, calor e água. A água é então recirculada para o eletrolisador e todo o processo tem início novamente.

\subsection{Células a combustível de cerâmica protônica.}

Este novo tipo de célula é baseado em um eletrólito cerâmico que apresenta alta condutividade protônica a temperaturas elevadas. Esta célula divide as vantagens de operar a altas temperaturas (cerca de $700^{\circ} \mathrm{C}$ ) com as células de carbonato fundido e de óxido sólido enquanto exibe os benefícios intrínsecos da condução de prótons das células de membrana de troca de prótons e de ácido fosfórico. A alta temperatura é necessária para se atingir eficiência com combustíveis a base de hidrocarbonetos. Os hidrocarbonetos podem ser oxidados diretamente no ânodo. Isto elimina o passo de produção de hidrogênio através da reforma externa de combustíveis. Moléculas gasosas de combustíveis à base de hidrocarbonetos são absorvidas na superfície do ânodo na presença de vapor de água, e os átomos de hidrogênio são liberados para serem absorvidos no eletrólito ${ }^{57}$.

Em células que operam a baixas temperaturas (membrana de troca de prótons, alcalina e ácido fosfórico) prótons ou íons hidroxila são os portadores de carga no eletrólito enquanto em células que operam a temperaturas mais elevadas (carbonato fundido e óxido sólido) os íons carbonato e oxigênio são os portadores de carga.

$\mathrm{Na}$ TAB. 3 são apresentadas as principais vantagens e desvantagens de cada tipo de célula bem como o estágio de desenvolvimento de cada uma. 
TABELA 3 - Vantagens, desvantagens e estágio de desenvolvimento das células a combustível ${ }^{56}$.

\begin{tabular}{|c|c|c|c|}
\hline Tipo & Vantagens & Desvantagens & Estágio de desenvolvimento \\
\hline AFC & $\begin{array}{l}\text { Materiais baratos, } \\
\text { tolerância a CO, auto } \\
\text { eficiência. }\end{array}$ & $\begin{array}{c}\text { O eletrólito é } \\
\text { corrosivo, intolerante } \\
\text { ao } \mathrm{CO}_{2} \text {, somente para } \\
\mathrm{H}_{2} \text { e } \mathrm{O}_{2} \text { puros }\end{array}$ & $\begin{array}{c}\text { Mercado comercial e } \\
\text { aplicações para defesa } \\
\text { (desenvolvimento pré- } \\
\text { comercial) }\end{array}$ \\
\hline PEMFC & $\begin{array}{c}\text { Correntes altas, } \\
\text { densidade de } \\
\text { potência, longa vida } \\
\text { operacional, fácil } \\
\text { operação, capacidade } \\
\text { cíclica } \\
\end{array}$ & $\begin{array}{l}\text { Intolerante ao CO, } \\
\text { controle da água, } \\
\text { catalisadores nobres } \\
\text { (caros e raros) }\end{array}$ & $\begin{array}{l}\text { Em fase de teste pré- } \\
\text { comercial ( escala kW ) } \\
\text { incluindo protótipos de } \\
\text { veículos e geração } \\
\text { estacionária }\end{array}$ \\
\hline DMFC & $\begin{array}{l}\text { Metanol Direto / } \\
\text { Alimentação com } \\
\text { água evitando reforma }\end{array}$ & $\begin{array}{c}\text { Complexo, } \\
\text { catalisadores nobres, } \\
\text { membrana é } \\
\text { permeável ao metanol }\end{array}$ & Em testes de laboratório \\
\hline PAFC & $\begin{array}{c}\text { Tecnologicamente } \\
\text { bem avançado }\end{array}$ & $\begin{array}{l}\text { Eficiência e duração } \\
\text { limitadas, corrosão, } \\
\text { catalisadores nobres }\end{array}$ & $\begin{array}{c}\text { Comercialmente disponível } \\
\text { em baixa quantidade, } \\
\text { geração de energia } \\
\text { estacionária }\end{array}$ \\
\hline MCFC & $\begin{array}{l}\text { Alta eficiência, } \\
\text { processamento de } \\
\text { combustível interno, } \\
\text { trabalha com altas } \\
\text { temperaturas. }\end{array}$ & $\begin{array}{l}\text { Controle complexo, } \\
\text { eletrólito instável, } \\
\text { duração limitada, } \\
\text { corrosão }\end{array}$ & $\begin{array}{c}\text { Geração de energia } \\
\text { estacionária, com sistema de } \\
\text { energia e calor combinados, } \\
\text { em fase de teste e comercial } \\
\text { (escala de } 200 \mathrm{~kW} \text { ) }\end{array}$ \\
\hline SOFC & $\begin{array}{l}\text { Processamento de } \\
\text { combustível interno, } \\
\text { trabalha com altas } \\
\text { temperaturas, } \\
\text { operação de longa } \\
\text { vida. }\end{array}$ & $\begin{array}{c}\text { Operação a altas } \\
\text { temperaturas, alto } \\
\text { custo e baixa potência } \\
\text { específica }\end{array}$ & $\begin{array}{c}\text { Em testes de } \\
\text { laboratório,campo ( escala de } \\
100 \mathrm{~kW}) \text {, comercial }(1 \mathrm{Kw}) \\
\text { tecnologia de cerâmica } \\
\text { processada, geração de } \\
\text { energia }\end{array}$ \\
\hline
\end{tabular}

Como se pode observar na tabela, os diferentes tipos de células a combustível e tecnologias associadas encontram-se em estágios distintos de desenvolvimento.

Algumas tecnologias estão sendo abandonadas como, por exemplo, a AFC, devido a problemas de sensibilidade a contaminantes, ou problemas de durabilidade. Outras como a PEMFC, SOFC e MCFC estão em desenvolvimento acelerado e já começam a entrar no mercado, enquanto as células de ácido fosfórico já estão disponíveis comercialmente ${ }^{56,57,58}$.

A cinética lenta de redução do oxigênio é um fator limitante na PEMFC e DMFC. A DMFC também apresenta limitações devido à lenta cinética de oxidação do metanol e ao cruzamento do metanol para o cátodo ${ }^{59,60,61}$. 


\subsubsection{2 - Métodos de Obtenção de Hidrogênio}

Dentre as várias tecnologias de produção de hidrogênio podemos destacar:

\subsection{Eletrólise}

Um dos métodos mais comuns para a obtenção de hidrogênio é a utilização de eletrolisadores. Os eletrolisadores são construídos com a disposição de diversos eletrodos em série. Com a aplicação de uma voltagem contínua, o hidrogênio é gerado no cátodo e o oxigênio no ânodo ${ }^{62,63}$.

A eletrólise é o processo de quebra da molécula de água através da passagem de uma corrente elétrica com a conseqüente liberação de hidrogênio no cátodo e oxigênio no anodo, que permite assim a utilização do hidrogênio. Como a eletrólise necessita de um suprimento de energia elétrica para ocorrer, a energia fotovoltaica e eólica são opções viáveis para a produção de hidrogênio em regiões mais afastadas, podendo ser esse hidrogênio usado como acumulador de energia em momentos de indisponibilidade de energia solar ou eólica.

Atualmente três sistemas de eletrolise são os mais utilizados, sendo que dois são formados por solução eletrolítica ${ }^{64}$.

\subsection{Eletrolisadores unipolares com eletrólito líquido alcalino $(\mathrm{KOH})$}

São utilizados devido à sua grande condutividade elétrica e funcionam com eletrodos conectados em paralelo e uma membrana que, colocada entre o anodo e o cátodo, separa o hidrogênio do oxigênio. É a tecnologia mais desenvolvida prestando-se bem a aplicações estacionárias e pressões acima de 25 bar. Os maiores desafios em relação à essa tecnologia estão na melhoria da sua eficiência, tempo de vida e custo ${ }^{64}$.

\subsection{Eletrolisadores bipolares com eletrólito líquido alcalino $(\mathrm{KOH})$}

Apresentam uma estrutura que lembra um filtro de prensa, pois é formado por "células" separadas por membranas e os eletrodos conectados em série. $O$ hidrogênio é produzido em um dos lados da membrana e o oxigênio no outro lado ${ }^{64}$. 


\subsection{Eletrolisadores com eletrólito sólido (membrana de troca protônica-PEM) \\ É a tecnologia mais recente e se presta tanto a aplicações} estacionárias como móveis, já que não utiliza líquido como eletrólito. A ausência de corrosão, a alta densidade de corrente e a capacidade de trabalhar em altíssimas pressões (centenas de bar), são as vantagens desse sistema. O maior desafio atualmente é aumentar o tempo de vida da membrana de troca de prótons.

Independentemente do tipo de eletrolisador a reação química que separa o hidrogênio do oxigênio na água é sempre a mesma:

$$
\mathrm{H}_{2} \mathrm{O} \rightarrow 1 / 2 \mathrm{O}_{2}+\mathrm{H}_{2}
$$

Ocorrem, porém, variações dessa reação em cada um dos eletrodos quando comparamos o sistema de eletrólito líquido (alcalino) com o sólido (membrana) ${ }^{64}$, levando a diferentes eficiências conforme as condições aplicadas aos eletrolisadores como mostra a TAB. 4

TABELA 4: Eficiência dos eletrolisadores para diferentes temperaturas e pressões $^{64}$.

\begin{tabular}{|c|c|c|c|c|c|}
\hline $\begin{array}{c}\mathbf{P} \\
\text { (bar) }\end{array}$ & $\begin{array}{c}\mathrm{T} \\
\left({ }^{\circ} \mathrm{C}\right)\end{array}$ & $\begin{array}{c}\text { Consumo } \\
\text { teórico } \\
\text { de eletricidade } \\
\left(\mathrm{GJ} / \mathrm{GJ} \mathrm{H} \mathrm{H}_{2}\right)\end{array}$ & $\begin{array}{c}\text { Consumo } \\
\text { Teórico de } \\
\text { calor } \\
(\text { GJ/GJH } \\
\text { (G) }\end{array}$ & $\begin{array}{l}\text { Consumo total } \\
\text { Teórico de } \\
\text { energia } \\
\left(\mathbf{G J} / \mathrm{GJH}_{2}\right)\end{array}$ & $\begin{array}{c}\text { Eficiência } \\
\text { Teórica } \\
(\%)\end{array}$ \\
\hline 1 & 25 & 0,98 & 0,20 & 1,18 & 84,6 \\
\hline 1 & 1000 & 0,74 & 0,63 & 1,37 & 73,1 \\
\hline 400 & 25 & 1,07 & 0,20 & 1,27 & 78,6 \\
\hline
\end{tabular}


A eficiência máxima teórica dos eletrolisadores fica por volta de $85 \%$, porém o que se tem disponível atualmente são sistemas que ficam bem abaixo disso, por volta de 40 a $50 \%$ em função de o sistema ser isolado ou ligado à rede de distribuição respectivamente ${ }^{65,66,67}$.

Além dos eletrolisadores de $\mathrm{KOH}$ e PEM, está sendo pesquisado o sistema à base de óxido fundido que promete bons resultados de eficiência, dependendo ainda do desenvolvimento de novos materiais cerâmicos ${ }^{64}$. $\mathrm{Na} T A B$. 5 é possível ver as principais características dos eletrolisadores já comercializados e em desenvolvimento. 
TABELA 5: Principais características dos eletrolisadores existentes e em pesquisa $^{67}$.

\begin{tabular}{|c|c|c|c|c|c|}
\hline Technologia & $\begin{array}{l}\text { Eletrolisador } \\
\text { convencional }\end{array}$ & $\begin{array}{c}\text { Eletrolisador } \\
\text { alcalino } \\
\text { avançado }\end{array}$ & $\begin{array}{l}\text { Eletrolisador de } \\
\text { membrana } \\
\text { inorgânica }\end{array}$ & $\begin{array}{l}\text { Eletrolisador } \\
\text { PEM }\end{array}$ & $\begin{array}{c}\text { Eletrolisador } \\
\text { de vapor/alta } \\
\text { temp. }\end{array}$ \\
\hline $\begin{array}{c}\text { Estágio de } \\
\text { desenvolvimento }\end{array}$ & $\begin{array}{c}\text { Unidades } \\
\text { comerciais em } \\
\text { grande escala }\end{array}$ & $\begin{array}{c}\text { Protótipos e } \\
\text { comercial }\end{array}$ & $\begin{array}{l}\text { Unidades } \\
\text { comerciais }\end{array}$ & $\begin{array}{c}\text { Protótipos e } \\
\text { comercial }\end{array}$ & $\begin{array}{c}\text { Testes de } \\
\text { laboratório e } \\
\text { inicio de } \\
\text { comercial }\end{array}$ \\
\hline $\begin{array}{c}\text { Voltagem da } \\
\text { célula }(\mathrm{V})\end{array}$ & $1,8-2,2$ & $1,5-2,5$ & $1,6-1,9$ & $1,4-2,0$ & $0,95-1,3$ \\
\hline $\begin{array}{c}\text { Densidade de } \\
\text { corrente }\left(\mathrm{A} / \mathrm{cm}^{2}\right)\end{array}$ & $0,13-0,25$ & $0,20-2,0$ & $0,2-1,0$ & $1,0-4,0$ & $0,3-1,0$ \\
\hline Temperatura $\left({ }^{\circ} \mathrm{C}\right)$ & $70-90$ & $80-145$ & $90-120$ & $80-150$ & $900-1000$ \\
\hline Pressão (bar) & $1-2$ & Acima de 120 & Acima de 40 & Acima de 400 & Acima de 30 \\
\hline Catodo & $\begin{array}{c}\text { Aço inox Ou } \\
\mathrm{Ni}\end{array}$ & $\begin{array}{c}\text { Catalisador } \\
\text { de } \mathrm{Ni}\end{array}$ & $\begin{array}{c}\text { Núcleo de óxido } \\
\text { Com base de } \\
\text { cobalto }\end{array}$ & $\begin{array}{c}\text { Fibra de } \\
\text { carbono E Pt }\end{array}$ & $\mathrm{Ni}$ \\
\hline Anodo & $\mathrm{Ni}$ & $\mathrm{Ni}$ ativo & $\begin{array}{c}\text { Núcleo de óxido } \\
\text { Com base de } \\
\text { cobalto }\end{array}$ & $\begin{array}{l}\text { Ti poroso com } \\
\text { propriedades } \\
\text { catalisadoras }\end{array}$ & $\begin{array}{l}\mathrm{Ni}-\mathrm{NiO} \text { ou } \\
\text { Perovisquita }\end{array}$ \\
\hline $\begin{array}{l}\text { Separador de } \\
\text { gases }\end{array}$ & $\begin{array}{c}\text { Asbestos } \\
1,2-1,7 \\
\text { Ohm/cm }\end{array}$ & $\begin{array}{c}\text { Asbestos }<100^{\circ} \mathrm{C} \\
\text { PBI-K-titanato } \\
\text { depositado em } \\
\text { teflon }>100^{\circ} \mathrm{C} \\
0,5-0,7 \mathrm{Ohm} / \mathrm{cm}^{2}\end{array}$ & $\begin{array}{c}\text { Membrana } \\
\text { patenteada de } \\
\text { Ácido } \\
\text { poliantimoniaco } \\
0,2-0,3 \mathrm{Ohm} / \mathrm{cm}^{2}\end{array}$ & $\begin{array}{c}\text { Multicamadas } \\
\text { de telas de } \\
\text { metal } \\
\text { expandido }\end{array}$ & Nenhum \\
\hline $\begin{array}{l}\text { Eletrólito } \\
25-35 \%\end{array}$ & $\begin{array}{c}25-40 \% \\
\mathrm{KOH}\end{array}$ & $\begin{array}{c}14-15 \% \\
\mathrm{KOH}\end{array}$ & $\begin{array}{l}\text { Perfluorsulfonico } \\
\mathrm{KOH}\end{array}$ & $\begin{array}{c}\text { Membrana ácida } \\
\text { sólida de } \mathrm{Y}_{2} \mathrm{O}_{3} \\
10-12 \mathrm{~mm} \\
0,46 \mathrm{Ohm} / \mathrm{cm}^{2}\end{array}$ & $\begin{array}{c}\mathrm{ZrO}_{380} \\
\text { estabilizado }\end{array}$ \\
\hline $\begin{array}{l}\text { Eficiência da } \\
\text { célula } \\
\text { (GJ H } \mathrm{H}_{2} / \mathrm{GJ} \text { el) }\end{array}$ & $66-69$ & $69-77$ & $73-81$ & $73-84$ & $81-86$ \\
\hline $\begin{array}{c}\text { Energia } \\
\text { necessária } \\
\left(\mathrm{KWh} / \mathrm{Nm}^{3} \mathrm{H}_{2}\right)\end{array}$ & $4,3-5,1$ & $3,8-4,3$ & 4,8 & $3,6-4,0$ & $2,5-3,5$ \\
\hline
\end{tabular}




\subsubsection{Gaseificação da Biomassa}

Podemos definir biomassa como toda matéria orgânica vegetal (terrestre ou aquática), formada a partir do processo de fotossíntese, na presença da luz solar ou a matéria que se origina de resíduos de animais, como fezes. Pode-se dizer que a biomassa é uma forma de armazenamento de uma pequena fração da energia solar que incide sobre a face da terra, na forma de ligações moleculares orgânicas, sendo que essa energia é liberada por processos biológicos (digestão) e termoquímicos ${ }^{68}$.

Em relação ao esgoto doméstico, o tratamento adequado, através de fermentação anaeróbia pode gerar grandes quantidades de metano $\left(\mathrm{CH}_{4}\right)$ que quando reformado pode ser utilizado em células a combustível. O mesmo ocorre com o lixo doméstico quando disposto de maneira correta na forma de aterro sanitário

A biomassa pode ser aproveitada de maneira direta através de queima para a geração de vapor e sua utilização em turbinas a vapor na geração de energia elétrica, sistema esse que descarrega no ambiente grandes quantidades de gases. Isto pode ser evitado utilizando-se o processo de gaseificação.

Nos últimos anos tem-se aprimorado a tecnologia em processos de gaseificação, implicando na melhoria dos equipamentos que utilizam o gás de síntese obtido neste processo para a geração de energia elétrica ${ }^{69,70}$.

A utilização da biomassa pode assumir vários aspectos em função da sua origem. Assim a biomassa levada em consideração para a elaboração deste trabalho é a produzida a partir da agricultura intensiva, como no caso da soja, milho, etc., do extrativismo como no caso da madeira retirada da região Amazônica e da silvicultura como o que acontece com as áreas de reflorestamento de eucalipto e pínus.

O aproveitamento da gaseificação da biomassa na América Latina ainda é pequeno quando comparado com outras regiões do planeta, que já estão tirando proveito de seus resíduos agrícolas para a geração de energia, como na FIG. 18 


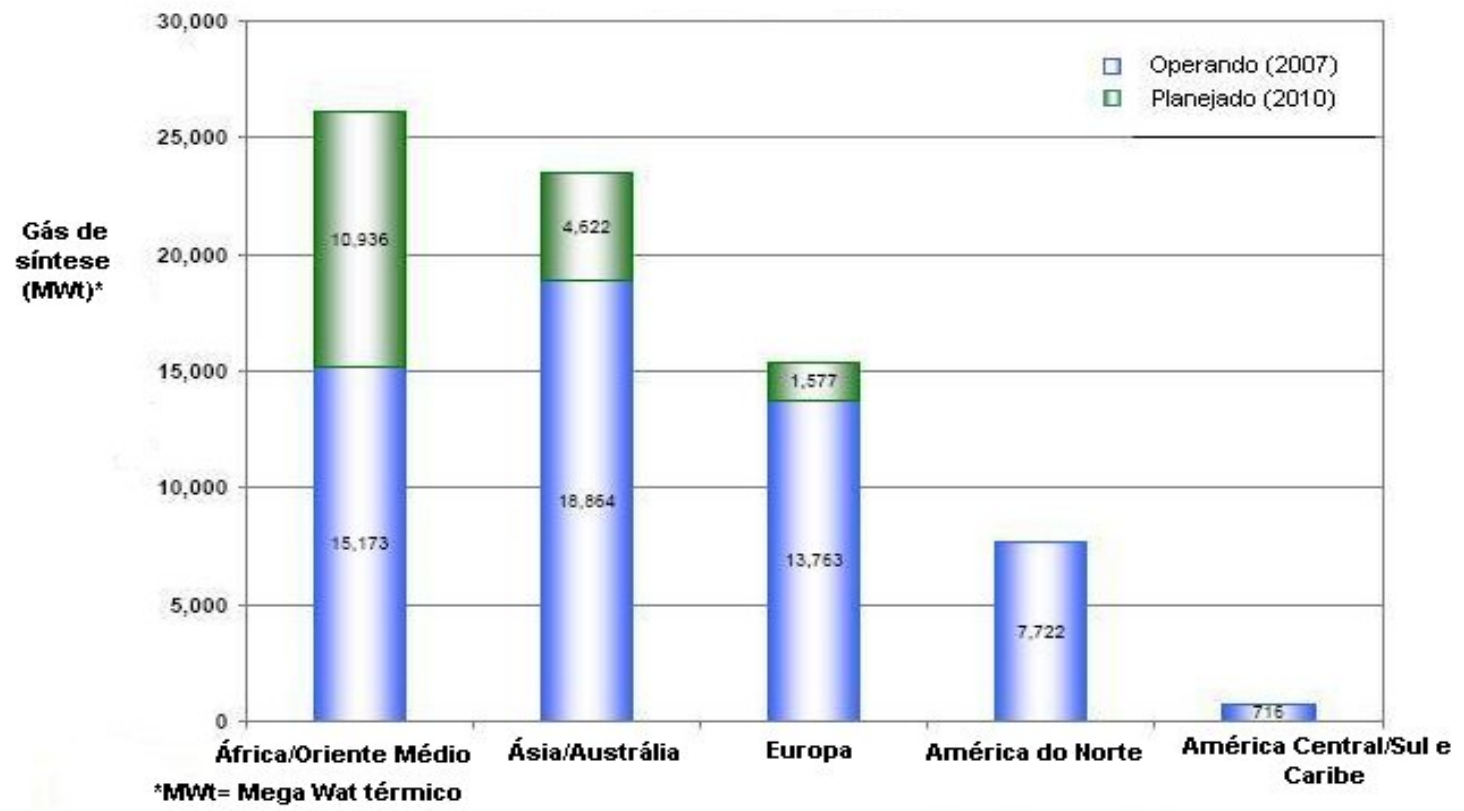

FIGURA 18: Gaseificação já em operação e planejamento nas regiões do planeta $^{70}$

A gaseificação da biomassa é um sistema endotérmico de duas fases durante o qual um combustível sólido como a biomassa é convertido em um gás de médio ou baixo potencial calórico. Na primeira fase (pirólise), os componentes da biomassa são aquecidos até a volatilização.

A pirólise se completa quando os componentes são volatilizados a temperaturas abaixo de $600^{\circ} \mathrm{C}$ através de uma série de complexas reações. $\mathrm{O}$ gás resultante contem hidrocarbonetos gasosos, hidrogênio, monóxido de carbono, dióxido de carbono, alcatrão, e vapor d'água ${ }^{71}$.

Na segunda fase da gaseificação, o monóxido de carbono e o dióxido de carbono sofrem nova reação com o vapor d'água liberado durante a pirólise ${ }^{72}$.

As reações que ocorrem no interior do gaseificador podem ser observadas na FIG. 19 


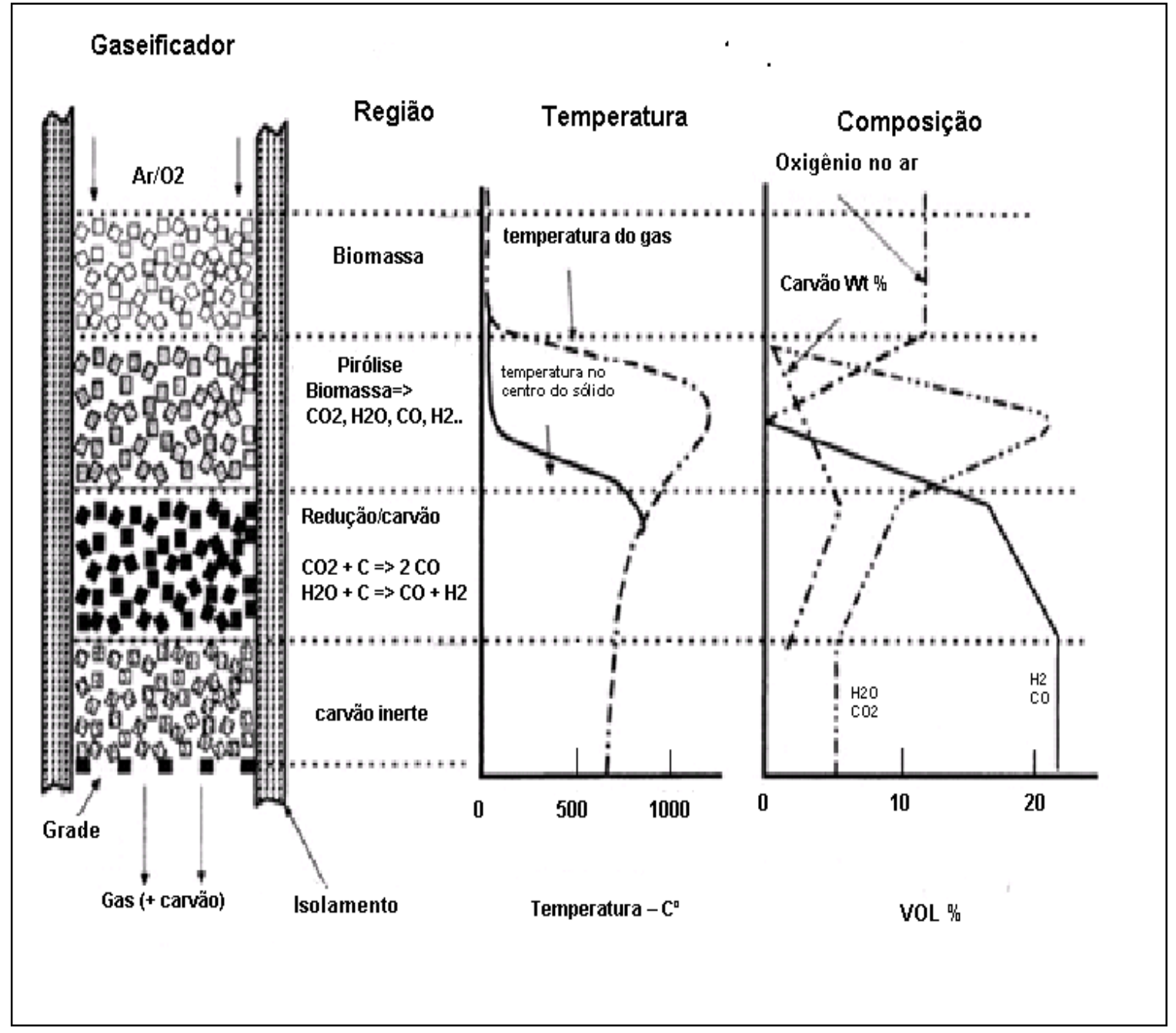

FIGURA 19: Seqüência de reações dentro do gaseificador ${ }^{72}$

Dois sistemas de gaseificadores de pequeno porte são os mais difundidos no mundo para a execução das reações necessárias para a obtenção do gás, conhecido como gás de síntese, onde um dos componentes é o hidrogênio ${ }^{73}$. 


\subsubsection{Gaseificador contracorrente}

É o sistema mais antigo e simples, utilizado principalmente na gaseificação do carvão mineral, sendo que a biomassa entra pelo topo do sistema e desce contra o fluxo de ar. Esse tipo de gaseificador pode trabalhar sob pressão atmosférica normal, ou pressurizado ${ }^{74}$, como é mostrado na FIG. 20.

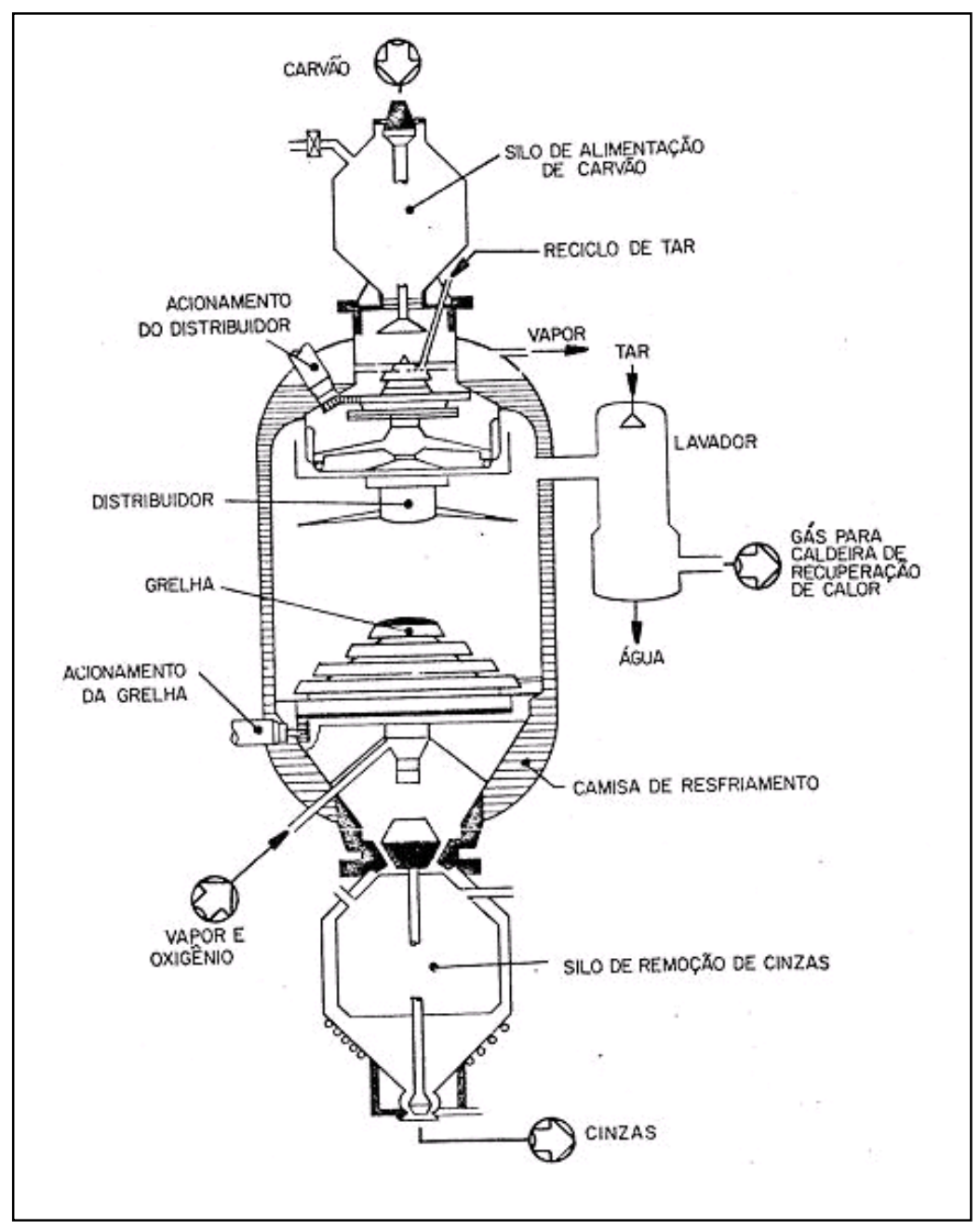

FIGURA 20: Gaseificador contracorrente (gaseificador pressurizado de Lurgi $)^{74}$.

Principais desvantagens desse sistema são: Apresentar alto teor de alcatrão gerado na pirólise (10 a 20\% com concentração de $100 \mathrm{~g} / \mathrm{Nm}^{3}$ ). Em função disso necessita de remoção do alcatrão para a utilização em motores, turbinas e células a combustível. Necessita de grande uniformidade na 
granulometria da biomassa utilizada para que não ocorra perda de carga. Pode ocorrer aumento excessivo de temperatura na grelha ${ }^{75}$.

Principais vantagens desse tipo de gaseificador é poder operar com biomassa com grande umidade, inclusive resíduos urbanos, apresentando assim uma grande simplicidade operacional.

\subsubsection{Gaseificador co-corrente.}

A diferença fundamental desse modelo de gaseificador está no fato da biomassa entrar em contato com o ar ou oxigênio (quando este é injetado) antes da pirólise sendo que os componentes da mistura descem por gravidade dentro do sistema.

Esse sistema de gaseificação vem sendo modificado e atualizado em vários centros de pesquisa como o NREL (National Renewable Energy Laboratory) nos USA e o IIS (Indian Institute of Science) na Índia. Sendo que atualmente o sistema de gaseificação co-corrente estratificado ${ }^{76,77,78,79}$, é o que vem sendo mais estudado, por operar com pressão atmosférica. Um desenho esquemático desse modelo de gaseificador pode ser visto na FIG. 21. 


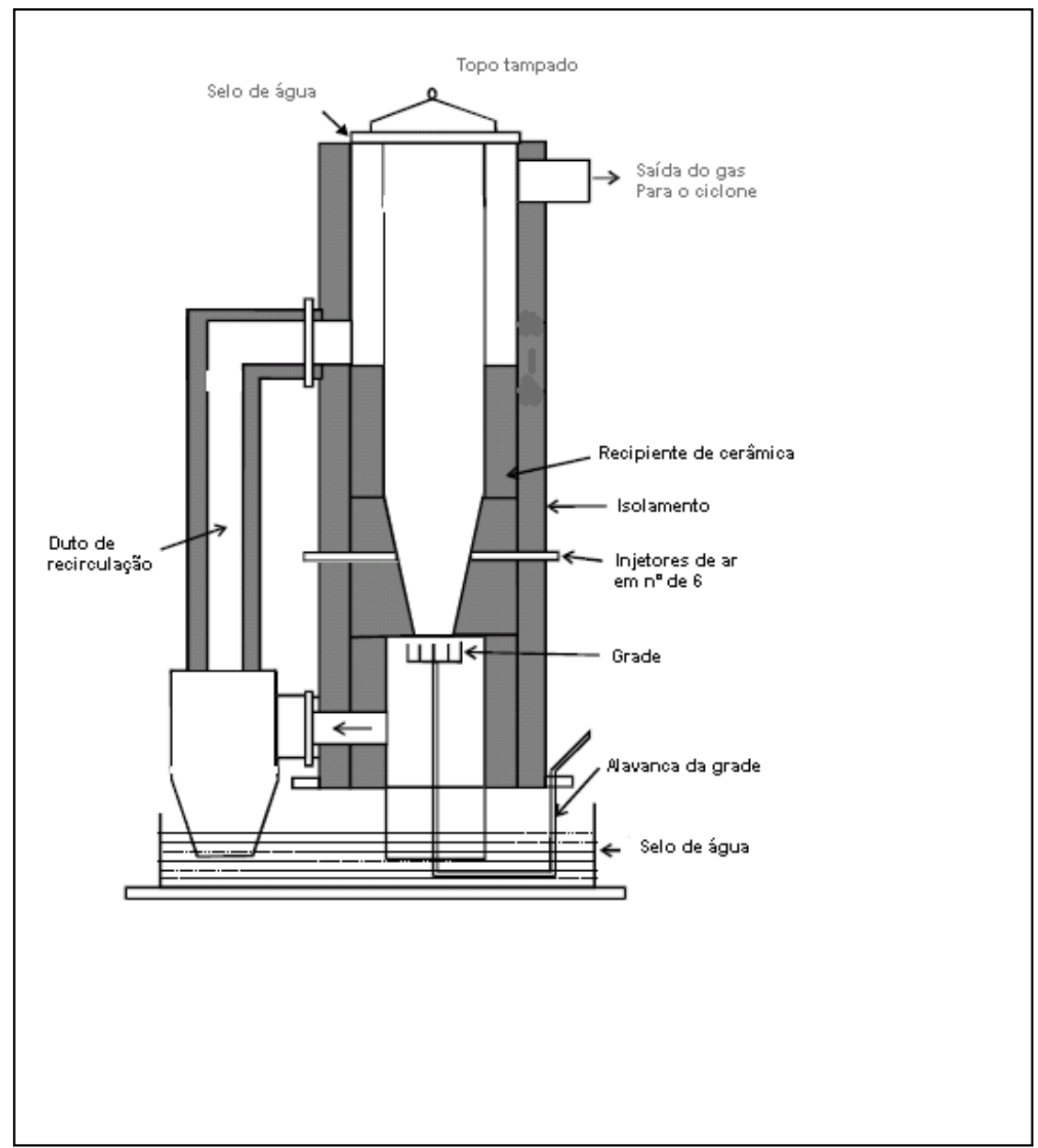

FIGURA 21: Gaseificador aberto $^{76}$.

As principais desvantagens desse tipo de gaseificador são: necessitar de uma biomassa com granulometria o mais uniforme possível e com umidade abaixo de $20 \%$, e a perda de energia em função da alta temperatura de saída do gás (acima de $600^{\circ} \mathrm{C}$ ).

As principais vantagens desse tipo de gaseificador são: praticamente todo o alcatrão é consumido no processo, sistema comprovado devido ao grande uso no passado e, por trabalhar com pressão atmosférica, apresenta baixo risco de explosão.

Este gaseificador produz um gás que apresenta a composição média, indicada na TAB. 6. 
TABELA 6: Composição média do gás em gaseificador co-corrente ${ }^{77}$.

\begin{tabular}{cc}
\hline Hidrogênio & $6,5 \pm 2 \%$ \\
\hline $\begin{array}{c}\text { Monóxido } \\
\text { De carbono }\end{array}$ & $19 \pm 1 \%$ \\
\hline Metano & $1,5 \pm 0,5 \%$ \\
\hline Dióxido & $12 \pm 1 \%$ \\
De carbono & \\
\hline Nitrogênio & $\pm 48 \%$ \\
\hline
\end{tabular}

Segundo BOWEN, D. e DASPPA, S. ${ }^{77,78,79,80}$, a quantidade de hidrogênio produzida com a utlização dos sistemas de gaseificação é em média $6,5 \%$ do resíduo de biomassa utilizado.

Com a utilização da gaseificação e a reforma a vapor o percentual de hidrogênio no gás resultante fica em torno de $12 \%{ }^{81,82}$, sendo esse o percentual que poderá ser utilizado para a produção de hidrogênio com a gaseificação da biomassa $^{83}$. 


\subsubsection{Reforma}

O método de melhor custo benefício utilizado na produção industrial de hidrogênio é a reforma de hidrocarbonetos na presença de vapor. Células a combustível funcionam com hidrogênio e qualquer material rico neste elemento pode servir como fonte de combustível. Podem ser utilizados combustíveis, como metanol, etanol, gás natural, destilados de petróleo, propano líquido, carvão gaseificado e uma grande diversidade de biomassa gaseificada. O hidrogênio é produzido a partir destes materiais pelo processo de reforma. Este processo é extremamente útil quando não é possível transportar e armazenar o hidrogênio ${ }^{84}$.

No caso do Brasil, considerando a enorme capacidade instalada de etanol, o desenvolvimento de reformadores de etanol, parece ser uma estratégia adequada à realidade do país. Entretanto, ainda se necessitam maiores pesquisas, principalmente para desenvolver catalisadores mais adequados ${ }^{85}$.

Novas abordagens vêm apresentando resultados com eficiências na faixa de $80 \%^{86}$, onde são utilizados catalisadores associados ao vapor.

A primeira fase do processo é a remoção de enxofre para níveis de ppb, tornando os processos subseqüentes mais fáceis.

O segundo passo é o processo primário onde são produzidos basicamente hidrogênio, monóxido de carbono e dióxido de carbono. Existem três tipos de processos primários: Oxidação parcial, reforma auto-térmica e reforma catalítica. Os processos de reforma necessitam de vapor diferentemente do processo de oxidação parcial, entretanto este último produz menos hidrogênio por unidade de combustível ${ }^{87}$.

O próximo passo é a redução do nível de monóxido de carbono pela adição de vapor. Finalmente são realizadas a purificação e o condicionamento para remover impurezas como amônia, e ajustar a temperatura e umidade para que o combustível possa entrar na célula.

Estes últimos passos nem sempre são necessários e dependem do tipo de combustível utilizado no processo de conversão. 


\subsubsection{Oxidação Parcial}

Neste método uma quantidade limitada de oxigênio é adicionada a um combustível fóssil (gás natural, óleo pesado, biomassa sólida, carvão) onde se obtém o hidrogênio que sempre necessita ser purificado ${ }^{88}$.

\subsubsection{Enzimas}

Outro método para gerar hidrogênio é através de bactérias ou algas. As cianobactérias produzem normalmente hidrogênio através de seu metabolismo. Elas podem crescer no ar ou na água e contêm enzimas que absorvem a luz solar e quebram as moléculas de água produzindo hidrogênio. As bactérias mais eficientes para este processo são as anaeróbias, o que é um problema, uma vez que um dos produtos da reação é o oxigênio ${ }^{89}$.

\subsubsection{Biohidrogênio}

É a mais recente forma de obtenção de hidrogênio estudada. É obtida a partir do esgoto não tratado, onde bactérias selecionadas inibem a fase metanogênica, produzindo diretamente o biohidrogênio ${ }^{90}$. 


\subsection{Situação atual da eletricidade no Brasil}

Com cerca de 8,5 milhões de quilômetros quadrados, mais de 7 mil quilômetros de litoral, o Brasil possui um dos maiores e melhores potenciais energéticos do mundo. Cerca de $90 \%$ do suprimento de energia elétrica brasileira provém de geração hídrica, sendo o restante dividido entre termoelétrica (14,7\%), nuclear $(2,5 \%)$ e importado $(8,5 \%)^{91}$.

Grande parte dos recursos energéticos do país está localizada em regiões pouco desenvolvidas, distantes dos grandes centros consumidores e com fortes restrições ambientais. Um dos grandes desafios brasileiros é o de promover o desenvolvimento econômico dessas regiões menos desenvolvidas, preservando a sua diversidade biológica, além de garantir o suprimento energético de regiões mais desenvolvidas.

Se na oferta de energia as condições são relativamente confortáveis, do lado da demanda há enormes descompassos e desafios para a sociedade brasileira. Tanto na periferia de grandes centros urbanos como em regiões remotas e pouco desenvolvidas, as formas convencionais de suprimento energético não atendem às necessidades socioeconômicas da maior parte da população.

A privação do serviço de energia elétrica, ou o atendimento precário, constituem fatores cada vez maiores de desigualdade na sociedade moderna e os seus custos estão concentrados nos segmentos sociais mais frágeis, que deveriam ser os maiores beneficiários desse acesso. Na TAB. 7 apresenta-se um resumo da situação da eletrificação das propriedades rurais no Brasil ${ }^{92}$. 
TABELA 7: Eletrificação dos domicílios permanentes no Brasil ${ }^{92}$.

\begin{tabular}{lccc}
\hline Região & $\mathrm{N}^{\circ}$ de domicílios & $\begin{array}{c}\mathrm{N}^{\circ} \text { de domicílios } \\
\text { eletrificados }\end{array}$ & $\begin{array}{c}\text { Domicílios } \\
\text { eletrificados (\%) }\end{array}$ \\
\hline Região Norte & 3.900 .000 & 3.668 .000 & 94,05 \\
\hline Região Nordeste & 14.252 .000 & 13.644 .000 & 95,73 \\
\hline Região Centro-Oeste & 4.163 .000 & 4.107 .000 & 98,65 \\
\hline Região Sudeste & 25.151 .000 & 25.092 .000 & 99,76 \\
\hline Região Sul & & & 99,45 \\
\hline Total Brasil & 8.879 .000 & 8.831 .000 & 98,22 \\
& 56.344 .000 & 55.342 .000 & \\
\hline
\end{tabular}

Os dados de $2008^{92}$ apontam para uma população de aproximadamente 3,6 milhões de pessoas moradoras em domicílios permanentes, no Brasil, que ainda não eram atendidas com iluminação elétrica. Pela mesma fonte, a parcela não residente em domicílios particulares permanentes era de 650 mil habitantes e a população rural da Região Norte podia ser estimada em cerca de 3,5 milhões de habitantes.

Os números apontavam para uma população total sem atendimento de cerca de 9,2 milhões de pessoas ou, aproximadamente, $5 \%$ da população, em um universo de 184 milhões de habitantes sem levar em conta a população de rua, historicamente ignorada nas contagens como mostra a FIG. $22^{93}$. 


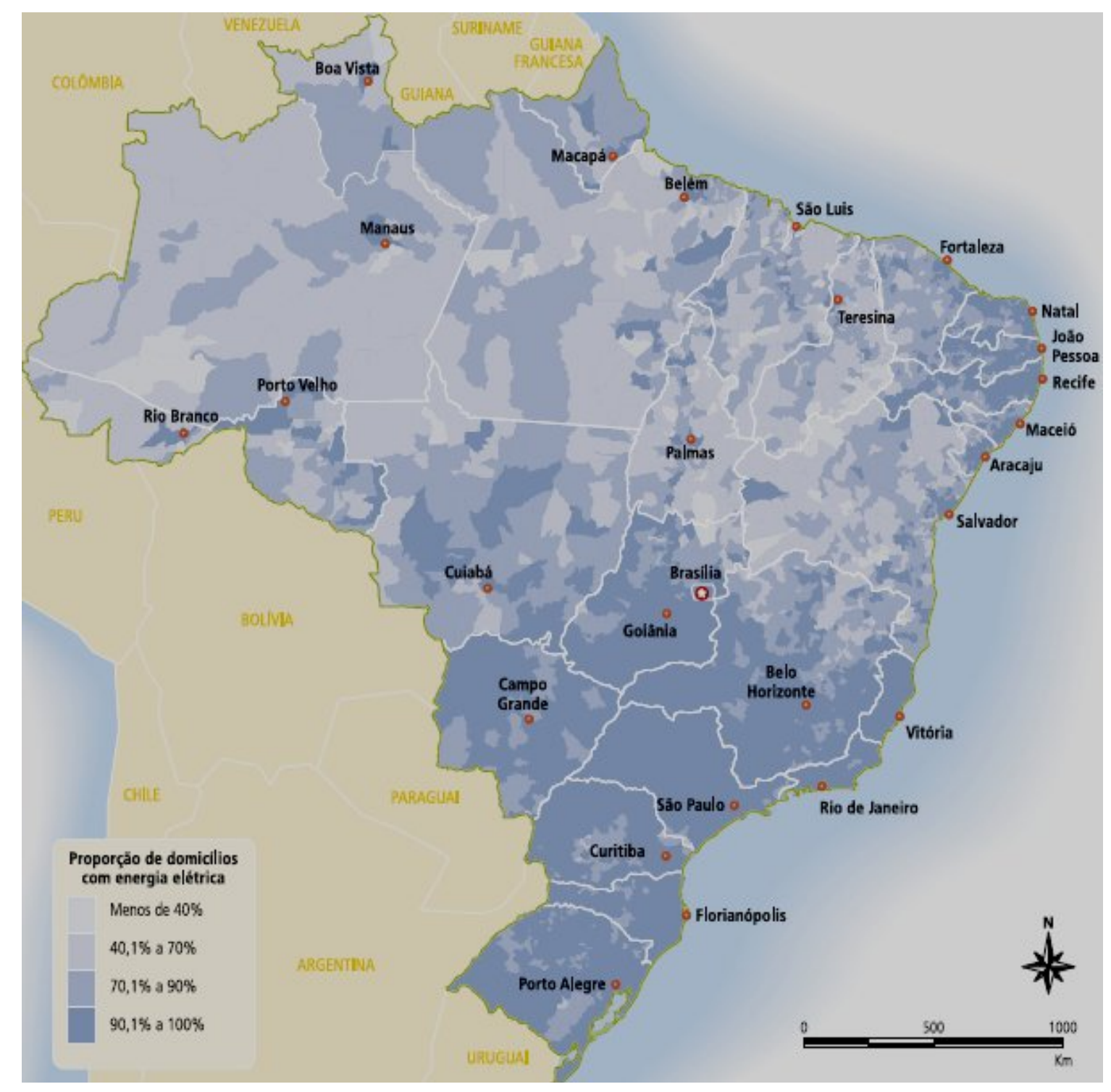

FIGURA 22: Mapa de eletrificação no Brasil ${ }^{91}$.

Por tudo isso se preconiza, então, a utilização de geração distribuída, que vem a ser a geração da energia, se possível, no próprio local de consumo ou o mais próximo deste, chegando-se à escolha de novas matrizes.

Sistemas sustentáveis de bioenergia e energia renovável devem ser embutidos na sociedade em contextos social, econômico e ambiental e dependem de apoio de muitas partes interessadas, com diferentes perspectivas. Esta complexidade constitui um grande obstáculo à implementação desses projetos de geração distribuída.

A interação entre a sociedade, o poder público e tecnologias de energias renováveis é um dos fatores críticos de sucesso da implementação da 
geração distribuída e que deve ser ativamente administrada, para que o desenvolvimento energético sustentável seja alcançado. Alguns autores sugerem que os projetos de energias renováveis são mais propensos ao fracasso, especialmente em áreas remotas. Dentre os principais motivos que os levam a esta afirmação estão a percepção dos riscos financeiros e políticos e a capacidade insuficiente para a implementação de projetos, sugerindo que existem desafios significativos para a transferência de energia renovável para as zonas rurais $^{93,94}$.

Vários estudos avaliam o potencial a concepção e implementação de projetos sustentáveis de energia ${ }^{95,96,97,98,99,100,101,102,103 . ~}$

No Brasil a abordagem da análise e discussão de métodos de apoio à tomada de decisões, quanto à escolha de matrizes energéticas deve também passar pela significativa contribuição quanto à sustentabilidade e a aspectos do desenvolvimento de mecanismo limpo (MDL), inserido ao Protocolo de Kyoto, do qual o país é signatário ${ }^{104}$.

Se a Europa, por exemplo, quiser alcançar sua meta de manter o aumento da temperatura abaixo de $2^{\circ} \mathrm{C}$ tem de lutar por um sistema de energia $100 \%$ renovável até 2050. Para tanto uma das abordagens estudadas é a descentralização da energia elétrica baseada na obtenção de energia a partir de resíduos $^{105}$. Os recentes avanços na utilização de resíduos para tecnologias energéticas centram-se na avaliação de novos desenvolvimentos de tecnologias e de unidades de tratamento térmico ${ }^{106}$. Os sistemas de gestão de resíduo têm aumentado nos últimos anos devido ao número crescente de problemas que afetam a vida de milhões de pessoas devido aos impactos ambientais negativos, podendo fornecer soluções econômicas sólidas ${ }^{107}$.

Mesmo dentre as fontes renováveis há as que causam maiores, ou menores, impactos ambientais. A FIG. 23 apresenta um modelo de substituição de energia primária no mundo, onde se observa a tendência de crescimento do hidrogênio a partir do ano $2000^{108}$. 


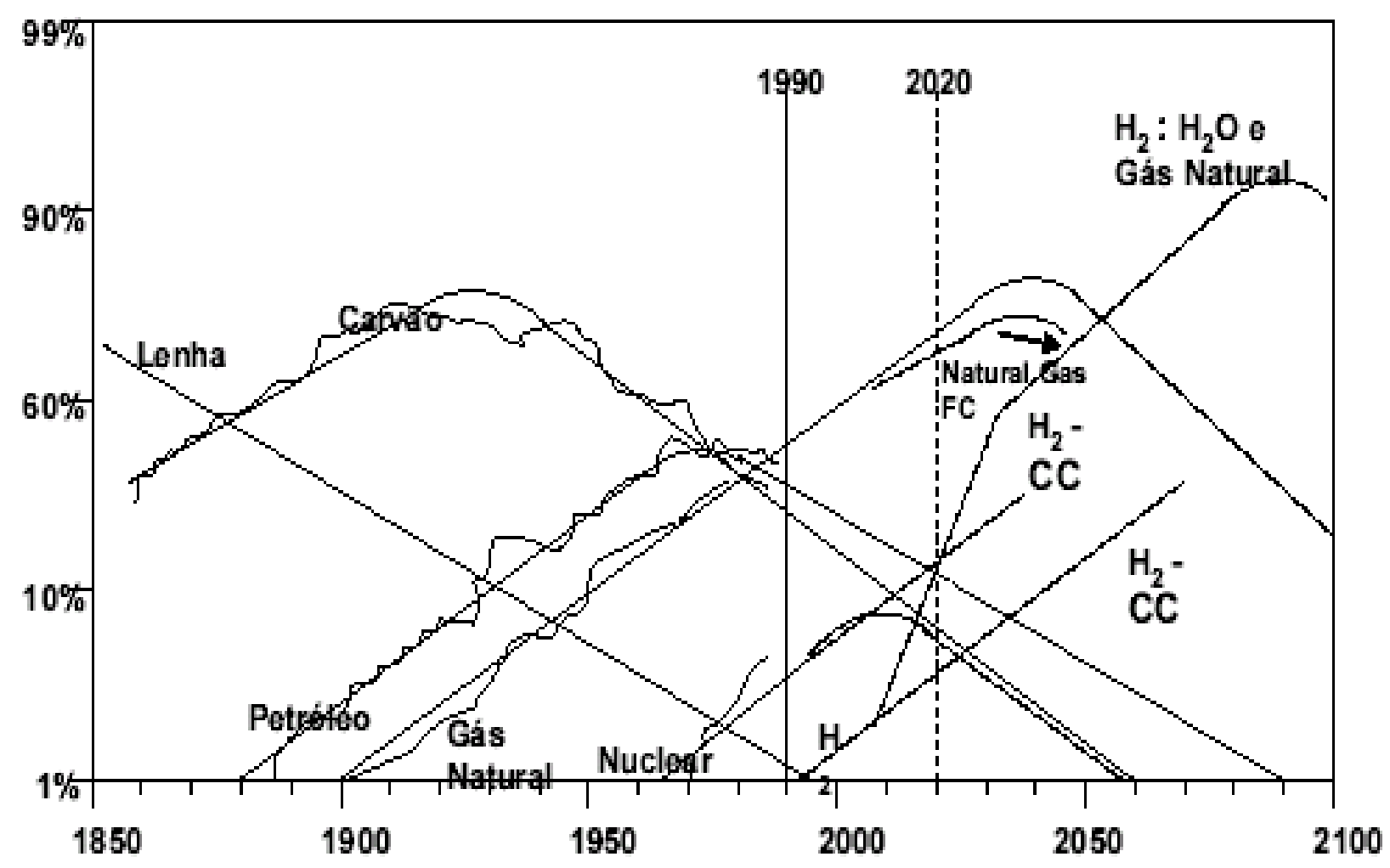

FIGURA 23: Modelo de substituição de energia primária ${ }^{108}$.

De acordo com o Departamento de Energia do Governo da América do Norte, o maior problema associado à produção de hidrogênio é a energia necessária para gerá-lo. Portanto, para que seja viabilizada a utilização da célula a combustível como sistema de geração distribuída, deve-se ter um sistema de produção de hidrogênio compatível com a região e dentro de parâmetros de custo e manutenção aceitáveis. Usando processos convencionais, o hidrogênio requer pelo menos duas vezes mais energia elétrica, duas vezes a quantidade de carvão ou duas vezes o número de painéis fotovoltaicos para gerar uma unidade equivalente de trabalho. Atualmente a maior parte do hidrogênio é produzida a partir do gás natural, o que é uma solução intermediária, uma vez que se descarta $30 \%$ da energia do gás natural para obter $70 \%$ de outro combustível $\left(\mathrm{H}_{2}\right)$, ocorrendo, além disso a emissão de $\mathrm{CO}_{2}$ para a atmosfera ${ }^{109}$. 
O grande desafio é desenvolverem-se métodos mais apropriados que utilizem fontes de energia sustentável. Alguns destes métodos já são bem conhecidos e utilizados em grande escala como a eletrólise e a reforma de combustíveis, enquanto outros se encontram em fase de testes em vários países.

No nosso país a biomassa pode ser utilizada como fonte para a geração de hidrogênio utilizando-se tanto a gaseificação como o potencial da energia eólica e solar, pouco aproveitadas em nosso território 


\section{RESULTADOS E DISCUSSÂO}

Como nosso país apresenta um grande potencial de aproveitamento de resíduos de biomassa em função da sua natural aptidão agrícola, foi escolhido como um dos pontos de partida para a avaliação da produção de hidrogênio, para este trabalho, a gaseificação e reforma do gás obtido a partir dos restos de plantações ou da atividade extrativista. O aproveitamento desses resíduos poderá, portanto, trazer um benefício ambiental à região. Deve-se ressaltar que apenas se levou em consideração a utilização de resíduos, para que não se entrasse na discussão da retirada de alimento à população para poder aumentar o potencial energético do país

Outra fonte considerada para a produção de hidrogênio através da eletrólise foi a fotovoltaica em função da grande quantidade de insolação recebida por nosso país devido à sua localização geográfica e do sub-aproveitamento dessa fonte de energia primária. Sendo que grandes áreas ociosas ou degradadas poderiam ser aproveitadas para a instalação de sistemas fotovoltaicos.

A terceira fonte considerada para a produção de hidrogênio, também através da eletrólise, foi a disponibilidade de ventos (energia eólica) em várias regiões de nosso país. Sendo que esse tipo de energia tem sido a que vem sofrendo a maior queda no seu custo de instalação devido a grandes avanços tecnológicos no aproveitamento de ventos de baixa velocidade o que aumenta em muito as possibilidades em nosso país.

\subsection{Quantidade de resíduos para gaseificação}

Para a elaboração dos cálculos referentes à produção de resíduos disponíveis foram utilizados os índices da TAB. 8 aplicados (multiplicados) sobre a quantidade de biomassa (em toneladas) de cada uma das culturas agrícolas escolhidas em função da existência do próprio índice e da sua importância em relação à quantidade que é produzida na região, segundo a literatura ${ }^{110,111,112}$.

Houve um amplo trabalho de pesquisa bibliográfica para se encontrar trabalhos que apontassem os resíduos que são deixados no campo, ou simplesmente abandonados após o beneficiamento. Alguns dados foram obtidos 
por meio de conversas telefônicas com técnicos ou pesquisadores de órgãos governamentais locais. Esses fatores levaram a uma implicação importante no resultado do trabalho, que seja a de que muito mais resíduos poderiam ser inseridos para a produção de energia desde que mais dados confiáveis, quanto às quantidades produzidas, pudessem ser utilizados.

TABELA 8: Tipo de resíduo e quantidade gerada em relação à produção.

\begin{tabular}{|c|c|c|}
\hline Cultura & $\begin{array}{l}\text { Tipo de } \\
\text { Resíduo }\end{array}$ & $\begin{array}{c}\text { Relação } \\
\text { resíduo/produto }\end{array}$ \\
\hline Algodão & Rama & 2,45 \\
\hline Amendoim & noz & 1,08 \\
\hline Arroz & Palha+casca & 1,49 \\
\hline $\begin{array}{l}\text { Cana de } \\
\text { açúcar }\end{array}$ & Palhada+bagaço & 0,28 \\
\hline $\begin{array}{l}\text { Castanha } \\
\text { De caju }\end{array}$ & Casca & 0,73 \\
\hline $\begin{array}{l}\text { Coco da } \\
\text { Bahia }\end{array}$ & Casca & 0,60 \\
\hline Feijão & Palha & 3,67 \\
\hline Mandioca & Folhas & 0,19 \\
\hline Milho & Palha & 1,42 \\
\hline Soja & Palha & 1,40 \\
\hline Trigo & Palha & 1,42 \\
\hline Madeira & $\begin{array}{l}\text { Pedaços } \\
\text { no campo }\end{array}$ & 0,17 \\
\hline
\end{tabular}


Para cada região fez-se um resumo das características geográficas e das condições climáticas ${ }^{113}$, pois esses são fatores que tornam distintos os tipos de agriculturas locais. 


\subsection{Região Nordeste}

Os estados que compõem a região Nordeste com suas respectivas capitais são mostrados na FIG. 23

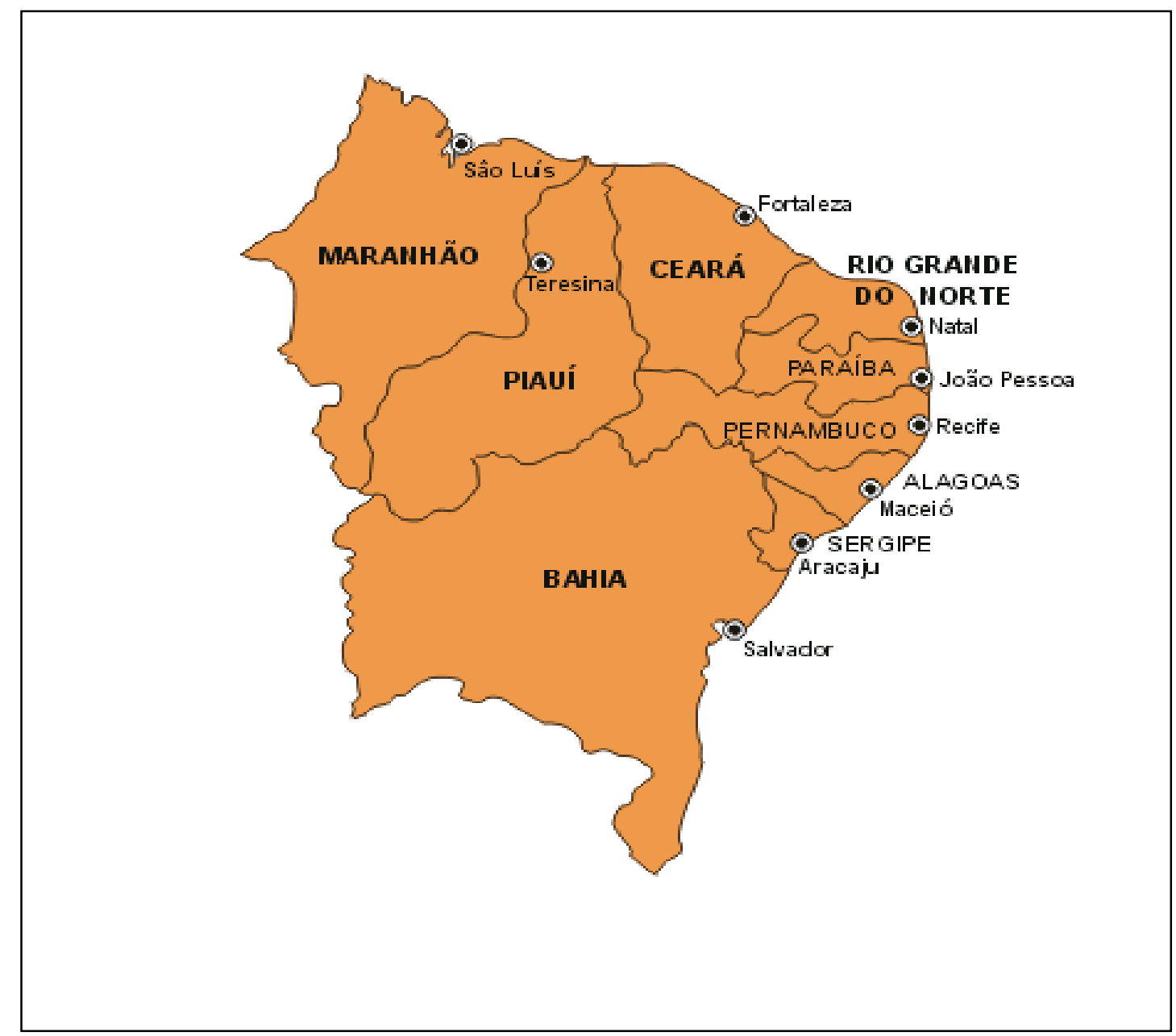

FIGURA 23: Mapa região Nordeste ${ }^{114}$.

A Região Nordeste é uma região do Brasil com 1.558.196 km² de área, 51.534.406 habitantes residentes e com uma densidade demográfica de 33,07 hab $/ \mathrm{Km}^{2}$ e é a terceira região em área.

É a região brasileira que possui a maior quantidade de estados: Alagoas, Bahia, Ceará, Maranhão, Paraíba, Piauí, Pernambuco (incluindo o Distrito Estadual de Fernando de Noronha), Rio Grande do Norte e Sergipe.

Uma das características importantes do relevo nordestino é a existência de dois antigos e extensos planaltos, o Borborema e a Bacia do Rio Parnaíba e de algumas áreas altas e planas que formam as chamadas chapadas, 
como a Diamantina e a Araripe. Entre essas regiões ficam algumas depressões, nas quais está localizado o sertão, que é uma região de clima semi-árido.

\subsubsection{A vegetação da região Nordeste}

Muito rica e diversificada, vai desde a Mata Atlântica no litoral à Mata dos Cocais no Meio-Norte, ecossistemas como os manguezais, a caatinga, o cerrado, as restingas, o agreste dentre outros, possuem fauna e flora exuberantes, diversas espécies endêmicas, uma boa parte da vida no planeta e animais ameaçados de extinção.

\subsubsection{Mata Atlântica}

Também chamada de Floresta tropical úmida de encosta, a mata atlântica estendia-se originalmente do Rio Grande do Norte até o Rio Grande do Sul. Em consequência dos desmatamentos, que ocorreram em função, principalmente, da indústria açucareira, hoje só resta cerca de $5 \%$ da vegetação original, dispersas em "ilhas". Foi na mata atlântica nordestina que começou o processo de extração do pau-brasil. É na transição entre a zona da mata e o sertão que encontramos a sub região conhecida como agreste onde são encontramos brejos.

\subsubsection{2 - Mata dos Cocais}

Formação vegetal de transição entre os climas semi-árido, equatorial e tropical sendo as espécies principais são o babaçu e a carnaúba. Os estados abrangidos por esse tipo de vegetação são o Maranhão, o Piauí, o Rio Grande do Norte, parte do Ceará e o Tocantins na Região Norte. Representa menos de 3\% da área do Brasil.

\subsubsection{3 - Cerrado}

Ocupa 25\% do território brasileiro, mas no Nordeste só abrange o sul do estado do Maranhão e o oeste da Bahia. Apresenta árvores de baixo porte, com galhos retorcidos, no chão é coberto por gramíneas e apresenta um solo de alta acidez. 


\subsubsection{Caatinga}

Vegetação típica do sertão, suas principais espécies são o pereiro, a aroeira, o aveloz e as cactáceas. É uma formação de vegetais xerófitos (vegetais de regiões secas), mas é muito rica ecologicamente.

\subsubsection{5 - Vegetação Litorânea e Matas Ciliares.}

$\mathrm{Na}$ categoria de vegetação litorânea podemos incluir os mangues, que é um riquíssimo ecossistema, local de moradia e reprodução dos caranguejos e importante para a preservação de rios, lagoas. Também podemos incluir as restingas e as dunas que são cenários bem conhecidos do Nordeste; Já as matas ciliares ou matas-galerias são comuns em regiões de cerrados, mas também podem ser vistas na Zona da Mata, são pequenas florestas que acompanham as margens dos rios, onde existe maior concetração de materiais orgânicos no solo, funcionam como uma proteção para os rios e mares.

\subsubsection{Clima}

A região Nordeste do Brasil, apresenta temperaturas elevadas cuja média anual varia de $20^{\circ}$ a $28^{\circ} \mathrm{C}$. Nas áreas situadas acima de 200 metros e no litoral oriental as temperaturas variam de $24^{\circ}$ a $26^{\circ} \mathrm{C}$. As médias anuais inferiores a $20^{\circ} \mathrm{C}$ encontram-se nas áreas mais elevadas da Chapada Diamantina e do Planalto da Borborema. O índice de precipitação anual varia de 300 a $2.000 \mathrm{~mm}$. Três dos quatro tipos de climas que existem no Brasil estão presentes no Nordeste, são eles:

\subsubsection{Clima equatorial úmido}

Presente em uma pequena parte do estado do Maranhão, na divisa com o Pará.

\subsubsection{Clima litorâneo úmido}

Presente do litoral da Bahia ao do Rio Grande do Norte. 


\subsubsection{Clima tropical}

Presente nos estados da Bahia, Ceará, Maranhão e Piauí.

\subsubsection{Clima tropical semi-árido}

Presente em todo o sertão nordestino.

4.2.3 - Avaliação da produção de resíduos da região Nordeste por estado.

Nas TAB. de 8 a 16 apresentam-se as mais importantes produções agrícolas, encontradas por meio de pesquisas feitas estado por estado da região Nordeste. Nelas encontram-se as produções anuais e a quantidade de resíduo produzida.. 
4.2.3.1 - Maranhão

TABELA 8: Produção-Unidade da Federação: Maranhão - Dezembro 2007

\begin{tabular}{cccc}
\hline Produto (t) & $\begin{array}{c}\text { Índice de } \\
\text { resíduos }\end{array}$ & $\begin{array}{c}\text { Produção } \\
(\mathbf{t})\end{array}$ & $\begin{array}{c}\text { Quantidade de } \\
\text { resíduos (t) }\end{array}$ \\
\hline Algodão herbáceo & 2,45 & 29.419 & 72.077 \\
Arroz & 1,49 & 683.358 & 1.018 .203 \\
Cana de açúcar & 0,28 & 2.412 .743 & 675.568 \\
Castanha de caju & 0,73 & 6.287 & 4.590 \\
Coco da baía & 0,60 & 3.906 & 3.344 \\
Feijão (1 ${ }^{\text {a }}$ e 2a safras) & 3,67 & 38.546 & 141.464 \\
Mandioca & 0,19 & 1.802 .217 & 335.212 \\
Madeira/ tora lenha & 0,18 & 2.087 .291 & 375.712 \\
Milho (1a safra) & 1,42 & 469.789 & 667.100 \\
Soja & 1,40 & 1.125 .054 & 1.575 .076 \\
\hline Total & & $\mathbf{8 . 6 5 8 . 6 1 0}$ & $\mathbf{4 . 8 6 7 . 3 4 6}$
\end{tabular}


TABELA 9: Produção-Unidade da Federação: Piauí - Dezembro 2007

\begin{tabular}{|c|c|c|c|}
\hline Produto $(t)$ & $\begin{array}{l}\text { Índice de } \\
\text { resíduos }\end{array}$ & Produção (t) & $\begin{array}{c}\text { Quantidade de } \\
\text { resíduos (t) }\end{array}$ \\
\hline Algodão herbáceo & 2,45 & 27.521 & 67.426 \\
\hline Arroz & 1,49 & 143.940 & 214.471 \\
\hline Cana de açúcar & 0,28 & 779.482 & 218.255 \\
\hline Castanha de caju & 0,73 & 23.744 & 17.333 \\
\hline Coco da baía & 0,60 & 8.711 & 5.227 \\
\hline $\begin{array}{l}\text { Feijão ( } 1^{a} \text { e } 2^{a} \\
\text { safras })\end{array}$ & 3,67 & 38.420 & 141.001 \\
\hline Mandioca & 0,19 & 550.656 & 102.422 \\
\hline $\begin{array}{c}\text { Madeira/ tora } \\
\text { lenha }\end{array}$ & 0,18 & 823.256 & 148.186 \\
\hline Milho (1a safra) & 1,42 & 170.730 & 242.437 \\
\hline Soja & 1,40 & 484.940 & 678.916 \\
\hline Total & & 3.051 .400 & 1.835 .674 \\
\hline
\end{tabular}




\subsubsection{Ceará}

TABELA 10: Produção-Unidade da Federação: Ceará - Dezembro 2007

\begin{tabular}{|c|c|c|c|}
\hline Produto (t) & $\begin{array}{l}\text { Índice de } \\
\text { resíduos }\end{array}$ & Produção (t) & $\begin{array}{c}\text { Quantidade de } \\
\text { resíduos (t) }\end{array}$ \\
\hline Algodão herbáceo & 2,45 & 4.693 & 11.498 \\
\hline Amendoim & 1,08 & 491 & 530 \\
\hline Arroz & 1,49 & 71.541 & 106.596 \\
\hline Café em grão & 0,40 & 3.361 & 1.344 \\
\hline Cana de açúcar & 0,28 & 2.251 .239 & 630.347 \\
\hline Castanha de caju & 0,73 & 53.419 & 74.787 \\
\hline Coco da baía & 0,60 & 105.257 & 63.154 \\
\hline $\begin{array}{c}\text { Feijão }\left(1^{a} \text { e } 2^{a}\right. \\
\text { safras })\end{array}$ & 3,67 & 129.512 & 475.309 \\
\hline Mandioca & 0,19 & 769.430 & 143.114 \\
\hline $\begin{array}{c}\text { Madeira/ tora } \\
\text { lenha }\end{array}$ & 0,18 & 2.087.291 & 375.712 \\
\hline Milho ( $1^{a}$ safra) & 1,42 & 358.768 & 509.451 \\
\hline Total & & 5.835 .002 & 2.391 .842 \\
\hline
\end{tabular}




\subsubsection{Rio Grande do Norte}

TABELA 11: Produção-Unidade da Federação: Rio Grande do Norte Dezembro 2007

\begin{tabular}{|c|c|c|c|}
\hline Produto (t) & $\begin{array}{l}\text { Índice de } \\
\text { resíduos }\end{array}$ & Produção (t) & $\begin{array}{c}\text { Quantidade de } \\
\text { resíduos (t) }\end{array}$ \\
\hline Algodão herbáceo & 2,45 & 3.734 & 9.148 \\
\hline Arroz & 1,49 & 5.060 & 7.539 \\
\hline Cana de açúcar & 0,28 & 3.836 .626 & 1.074 .255 \\
\hline Castanha de caju & 0,73 & 40.515 & 29.576 \\
\hline Coco da baía & 0,60 & 30.163 & 18.098 \\
\hline $\begin{array}{l}\text { Feijão }\left(1^{a} \text { e } 2^{a}\right. \\
\text { safras })\end{array}$ & 3,67 & 20.812 & 76.380 \\
\hline Mandioca & 0,19 & 566.366 & 105.344 \\
\hline $\begin{array}{l}\text { Madeira/ tora } \\
\text { lenha }\end{array}$ & 0,18 & 672.694 & 121.085 \\
\hline Milho ( $1^{a}$ safra) & 1,42 & 28.191 & 40.031 \\
\hline Total & & 5.204 .161 & 1.481 .457 \\
\hline
\end{tabular}




\subsubsection{Paraíba}

TABELA 12: Produção-Unidade da Federação: Paraíba - Dezembro 2007

\begin{tabular}{cccc}
\hline Produto $(\mathbf{t})$ & $\begin{array}{c}\text { Índice de } \\
\text { resíduos }\end{array}$ & Produção (t) & $\begin{array}{c}\text { Quantidade de } \\
\text { resíduos (t) }\end{array}$ \\
\hline Algodão herbáceo & 2,45 & 2.884 & 7.066 \\
Arroz & 1,49 & 5.044 & 7.516 \\
Cana de açúcar & 0,28 & 6.222 .223 & 1.742 .222 \\
Castanha de caju & 0,73 & 2.901 & 2.118 \\
Coco da baía & 0,60 & 30.845 & 18.507 \\
$\begin{array}{c}\text { Feijão (1a e } 2^{\mathrm{a}} \\
\text { safras) }\end{array}$ & 3,67 & 64.672 & 237.346 \\
$\begin{array}{c}\text { Mandioca } \\
\text { Madeira/ tora } \\
\text { lenha }\end{array}$ & 0,19 & 286.292 & 53.250 \\
$\begin{array}{c}\text { Milho (19a safra) } \\
\text { Total }\end{array}$ & 0,18 & 281.358 & 50.645 \\
\hline
\end{tabular}




\subsubsection{Pernambuco}

TABELA 13: Produção-Unidade da Federação: Pernambuco - Dezembro 2007

\begin{tabular}{cccc}
\hline Produto (t) & $\begin{array}{c}\text { Índice de } \\
\text { resíduos }\end{array}$ & Produção (t) & $\begin{array}{c}\text { Quantidade de } \\
\text { resíduos (t) }\end{array}$ \\
\hline Algodão herbáceo & 2,45 & 2.321 & 5.686 \\
Arroz & 1,49 & 19.141 & 28.520 \\
Cana de açúcar & 0,28 & 17.595 .676 & 4.926 .789 \\
Café em grão & 0,40 & 3.011 & 1.204 \\
$\begin{array}{c}\text { Coco da baía } \\
\text { Feijão (1a e 2 } \\
\text { safras) }\end{array}$ & 0,60 & 67.539 & 40.523 \\
$\begin{array}{c}\text { Mandioca } \\
\text { Madeira/ tora } \\
\text { lenha }\end{array}$ & 3,67 & 125.072 & 459.014 \\
$\begin{array}{c}\text { Milho (19a safra) } \\
\text { Total }\end{array}$ & 0,19 & 660.451 & 122.844 \\
\hline
\end{tabular}


4.2.3.6 Alagoas

TABELA 14: Produção-Unidade da Federação: Alagoas - Dezembro 2007

\begin{tabular}{|c|c|c|c|}
\hline Produto (t) & $\begin{array}{l}\text { İndice de } \\
\text { resíduos }\end{array}$ & Produção (t) & $\begin{array}{l}\text { Quantidade de } \\
\text { resíduos (t) }\end{array}$ \\
\hline Algodão herbáceo & 2,45 & 5.400 & 13.230 \\
\hline Arroz & 1,49 & 14.000 & 20.860 \\
\hline Cana de açúcar & 0,28 & 24.920 .000 & 6.977 .600 \\
\hline Coco da baía & 0,60 & 25.900 & 15.540 \\
\hline $\begin{array}{l}\text { Feijão }\left(1^{a} \text { e } 2^{a}\right. \\
\text { safras })\end{array}$ & 3,67 & 49.750 & 182.583 \\
\hline Mandioca & 0,19 & 248.400 & 46.202 \\
\hline $\begin{array}{c}\text { Madeira/ tora } \\
\text { lenha }\end{array}$ & 0,18 & 35.196 & 6.335 \\
\hline Milho ( $1^{a}$ safra) & 1,42 & 59.500 & 84.490 \\
\hline Total & & 25.358 .146 & 7.346 .840 \\
\hline
\end{tabular}




\subsubsection{SERGIPE}

TABELA 15: Produção-Unidade da Federação: Sergipe - Dezembro 2007

\begin{tabular}{cccc}
\hline Produto (t) & $\begin{array}{c}\text { Índice de } \\
\text { resíduos }\end{array}$ & Produção (t) & $\begin{array}{c}\text { Quantidade de } \\
\text { resíduos (t) }\end{array}$ \\
\hline Arroz & 1,49 & 53.265 & 79.365 \\
Cana de açúcar & 0,28 & 2.401 .966 & 672.550 \\
Coco da baía & 0,60 & 64.728 & 38.837 \\
$\begin{array}{c}\text { Feijão (1 }{ }^{\mathrm{a}} \text { e } 2^{\mathrm{a}} \\
\text { safras) }\end{array}$ & 3,67 & 22.374 & 82.113 \\
$\begin{array}{c}\text { Mandioca } \\
\text { Madeira/ tora } \\
\text { lenha }\end{array}$ & 0,19 & 498.233 & 92.671 \\
Milho (1 & 0,18 & 216.385 & 38.949 \\
\hline safra) & 1,42 & 237.129 & 336.723 \\
\hline Total & & 3.494 .080 & $\mathbf{1 . 3 4 1 . 2 0 8}$ \\
\hline
\end{tabular}




\subsubsection{BAHIA}

TABELA 16: Produção-Unidade da Federação: Bahia - Dezembro 2007

\begin{tabular}{|c|c|c|c|}
\hline Produto (t) & $\begin{array}{l}\text { Índice de } \\
\text { resíduos }\end{array}$ & Produção (t) & $\begin{array}{c}\text { Quantidade de } \\
\text { resíduos (t) }\end{array}$ \\
\hline Algodão herbáceo & 2,45 & 1.045 .240 & 2.560 .838 \\
\hline Amendoim & 1,08 & 8.719 & 9.417 \\
\hline Arroz & 1,49 & 41.547 & 61.905 \\
\hline Café em grão & 0,40 & 140.565 & 56.226 \\
\hline Cana de açúcar & 0,28 & 6.275 .410 & 1.757 .115 \\
\hline Castanha de caju & 0,73 & 6.345 & 4.632 \\
\hline Coco da baía & 0,60 & 314.444 & 188.666 \\
\hline $\begin{array}{l}\text { Feijão }\left(1^{a} \text { e } 2^{a}\right. \\
\text { safras })\end{array}$ & 3,67 & 350.944 & 1.287 .964 \\
\hline Mandioca & 0,19 & 4.710 .015 & 876.063 \\
\hline $\begin{array}{c}\text { Madeira/ tora } \\
\text { lenha }\end{array}$ & 0,18 & 5.913 .747 & 1.064 .475 \\
\hline Milho ( $1^{\text {a }}$ safra) & 1,42 & 1.672 .598 & 2.375 .089 \\
\hline Soja & 1,40 & 2.298 .000 & 3.217 .200 \\
\hline Total & & 22.777.574 & 13.459 .590 \\
\hline
\end{tabular}


A TAB. 17 mostra o total das produções agrícolas escolhidas e os resíduos gerados por elas na região Nordeste, por estado.

TABELA 17: Produção total da região Nordeste das culturas escolhidas Dezembro 2007

\begin{tabular}{ccc}
\hline Estado & $\begin{array}{c}\text { Produção Anual } \\
(\mathbf{t})\end{array}$ & $\begin{array}{c}\text { Quantidade de } \\
\text { resíduos } \\
\text { Anual(t) }\end{array}$ \\
Maranhão & 6.139 .526 & 4.867 .346 \\
Piauí & 2.259 .690 & 1.835 .674 \\
Ceará & 3.983 .227 & 2.391 .842 \\
R. G. do Norte & 4.138 .198 & 1.481 .457 \\
Paraíba & 6.670 .406 & 2.223 .313 \\
Pernambuco & 18.728 .062 & 5.993 .070 \\
Alagoas & 25.126 .370 & 7.346 .840 \\
Sergipe & $\mathbf{2 . 8 0 4 . 6 5 6}$ & 1.341 .208 \\
Bahia & 15.612 .944 & 13.459 .590 \\
\hline Total & $\mathbf{8 5 . 4 6 3 . 0 7 9}$ & $\mathbf{4 0 . 9 4 0 . 3 4 0}$ \\
\hline
\end{tabular}




\subsection{Região Norte}

Os estados que compõem a região Nordeste com suas respectivas capitais são mostrados na FIG. 24.

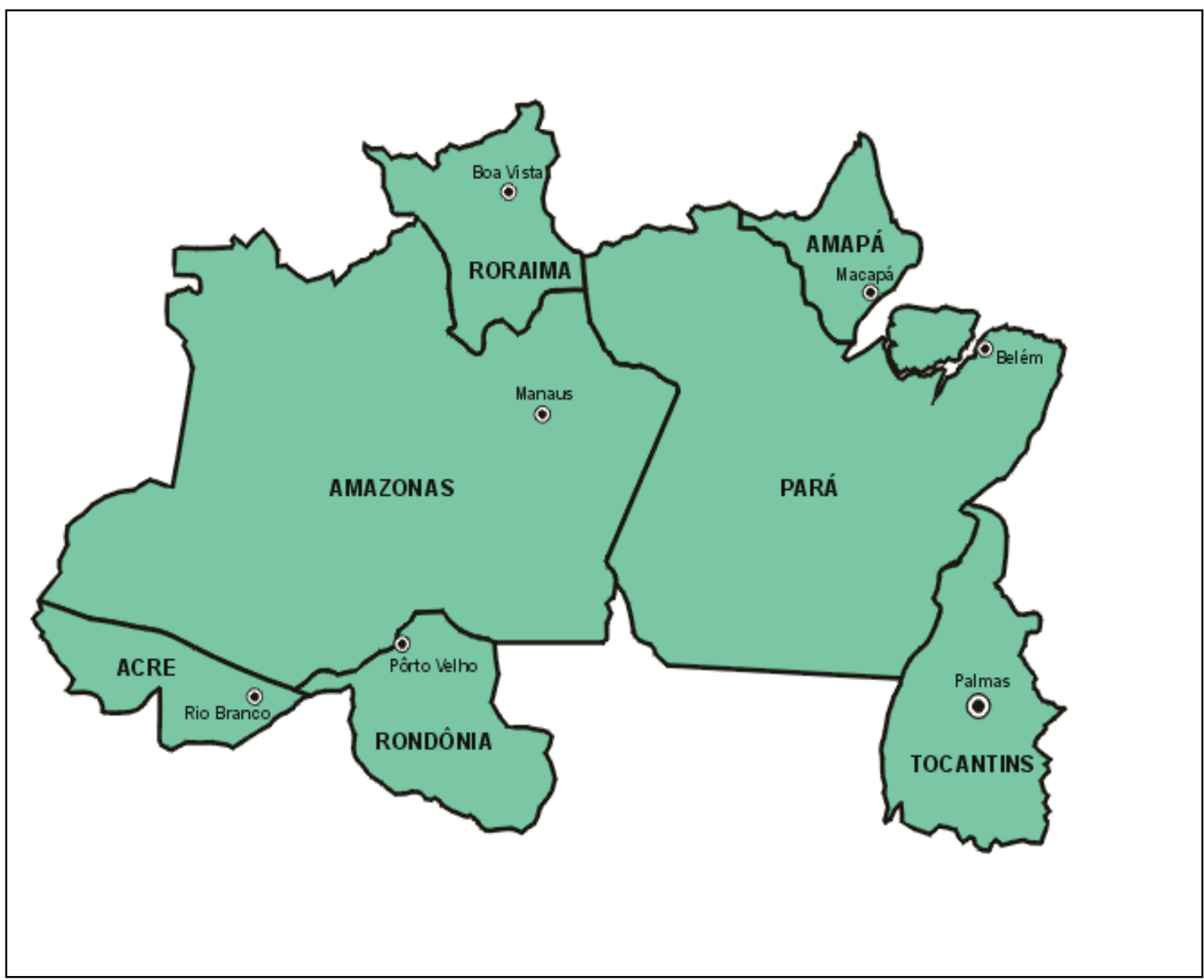

FIGURA 24: Mapa da Região Norte ${ }^{114}$.

A Região Norte é uma região do Brasil com $3.853 .023 \mathrm{~km}^{2}$ de área, 14.623.316 habitantes residentes e com uma densidade demográfica de 3,79 hab/ $/ \mathrm{Km}^{2}$ e é a terceira região em área.

É a região brasileira que possui a menor densidade demográfica e é formada pelos seguintes estados: Rondônia, Acre, Amazonas, Roraima, Pará, Amapá e Tocantins.

A Região Norte está localizada na região geoeconômica da Amazônia entre o Maciço das Guianas (ao norte), o Planalto Central (ao sul), a Cordilheira dos Andes (a oeste) e o Oceano Atlântico (a noroeste). Na região predomina o 
clima equatorial com exceção do norte do Pará, do sul do Amazonas e de Rondônia onde o clima é tropical.

Na região predominam os seguintes aspectos naturais: floresta densa e heterogênea, clima quente e úmido, rios extensos e caudalosos drenando terras de altitude geralmente pouco elevada.

\subsubsection{A vegetação da região Norte.}

Na Região Norte está localizada, em um importante ecossistema para o planeta, a Amazônia. Além da Amazônia, a região apresenta uma pequena faixa de mangue (no litoral), alguns pontos de cerrado e também alguns pontos de matas galerias.

Equivalendo a mais de um terço das reservas florestais do mundo, é uma formação tipicamente higrófila, com o predomínio de árvores grandes e largas (espécies latifoliadas), muito próximas umas das outras e entrelaçadas por grande variedade de lianas (cipós lenhosos) e epífitas (vegetais que se apóiam em outros). O clima da região, quente e chuvoso, permite o crescimento das espécies vegetais e a reprodução das espécies animais durante o ano todo. Isso faz com que a Amazônia tenha a flora mais variada do planeta, além de uma fauna muito rica em pássaros, peixes e insetos.

A Floresta Amazônica apresenta algumas variações de aspecto, conforme o local, junto aos rios, nas áreas permanentemente alagadas, surge a mata de igapó, com árvores mais baixas. Mais para o interior surgem associações de árvores mais altas, conhecidas como mata de várzea, inundadas apenas durante as cheias. As áreas mais distantes do leito dos rios, inundadas somente por ocasião das grandes enchentes, são chamadas de mata de terra firme ou caaetê, que significa mata (caa) de proporções grandiosas.

\subsubsection{Clima}

A existência de calor e da enorme massa líquida favorecem a evaporação e fazem da Região Norte uma área bastante úmida. Dominada assim por um clima do tipo equatorial, a região apresenta temperaturas elevadas o ano todo (médias de $24^{\circ} \mathrm{C}$ a $26^{\circ} \mathrm{C}$ ), uma baixa amplitude térmica, com exceção de algumas áreas de Rondônia e do Acre, onde ocorre o fenômeno da friagem, em 
virtude da atuação do El Niño, permitindo que massas de ar frio vindas do oceano Atlântico sul penetrem na região.

O regime de chuvas na região é bem marcado, havendo um período seco, de junho a novembro e outro com grande volume de precipitação, de Dezembro a Maio. As chuvas provocam mais de $2.000 \mathrm{~mm}$ de precipitação anuais, havendo trechos com mais de $3.000 \mathrm{~mm}$, como o litoral do Amapá, a foz do rio Amazonas e porções da Amazônia Ocidental.

A Região Norte apresenta o clima mais úmido do Brasil, sendo comum a ocorrência de fortes chuvas. São características da região as chuvas de convecção ou de "hora certa", que em geral ocorrem no final da tarde e se formam da seguinte maneira: com o nascer do Sol, a temperatura começa a subir, ou seja, aumentar em toda a região, aquecimento que provoca a evaporação; o vapor de água no ar se eleva, formando grandes nuvens; com a diminuição da temperatura, causada pelo passar das horas do dia, esse vapor de água se precipita, caracterizando as chuvas de "hora certa".

\subsubsection{Hidrologia}

A região apresenta a maior bacia hidrográfica do mundo, a bacia amazônica, formada pelo rio Amazonas e seus milhares de afluentes. A foz do rio Amazonas apresenta um dos fenômenos naturais mais impressionantes que existe, a pororoca, uma perigosa onda contínua com até $5 \mathrm{~m}$ de altura, formada na subida da maré.

$\mathrm{Na}$ foz do rio Amazonas encontra-se a Ilha de Marajó, a maior ilha de água fluvio marítima do mundo, com aproximadamente $50.000 \mathrm{~km}^{2}$, que também abriga o maior rebanho de búfalos do país.

Além da presença da bacia amazônica, na região está localizada também boa parte da bacia do Tocantins.

Com a avaliação das produções agrícolas feitas estado por estado da região Norte foi possível elaborar as TAB de 18 a 24 , onde são mostradas as produções anuais por estado e a quantidade de resíduo produzida. 


\subsubsection{Avaliação da produção de resíduos da região Norte por estado.}

Nas TAB. De 18 a 24) apresentam-se as mais importantes produções agrícolas, encontradas por meio de pesquisas feitas estado por estado da região Norte. Nelas encontram-se as produções anuais e a quantidade de resíduo produzida.

\subsubsection{Rondônia}

TABELA 18: Produção-Unidade da Federação: Rondônia-Dezembro 2007

\begin{tabular}{cccc}
\hline Produto (t) & $\begin{array}{c}\text { Índice de } \\
\text { resíduos }\end{array}$ & Produção (t) & $\begin{array}{c}\text { Quantidade de } \\
\text { resíduos (t) }\end{array}$ \\
\hline Arroz & 1,49 & 145.502 & 216.798 \\
Café beneficiado & 0,40 & 88.639 & 35.456 \\
Castanha do Pará & 0,73 & 2.652 & 1.936 \\
Coco da Bahia & 0,60 & 10.578 & 6.347 \\
$\begin{array}{c}\text { Feijão (1a e 2a } \\
\text { safras) }\end{array}$ & 3,67 & 42.285 & 155.185 \\
Mandioca & 0,19 & 530.521 & 100.799 \\
Madeira em tora & 0,18 & 492.960 & 88.733 \\
Milho (19a safra) & 1,42 & 249.927 & 354.896 \\
Soja & 1,40 & 259.069 & 362.697 \\
\hline Total & & 1.822 .133 & 1.322 .847
\end{tabular}




\subsubsection{Acre}

TABELA 19: Produção-Unidade da Federação: Acre - Dezembro 2007

\begin{tabular}{cccc}
\hline Produto (t) & $\begin{array}{c}\text { Índice de } \\
\text { resíduos }\end{array}$ & Produção (t) & $\begin{array}{c}\text { Quantidade de } \\
\text { resíduos (t) }\end{array}$ \\
\hline Arroz & 1,49 & 28.099 & 41.868 \\
Café beneficiado & 0,40 & 1.367 & 547 \\
Cana de açúcar & 0,28 & 35.248 & 9.869 \\
$\begin{array}{c}\text { Castanha do Pará } \\
\text { Feijão (1a e 2a } \\
\text { safras) }\end{array}$ & 0,73 & 10.217 & 7.458 \\
$\begin{array}{c}\text { Mandioca } \\
\begin{array}{c}\text { Madeira / tora } \\
\text { lenha }\end{array}\end{array}$ & 3,67 & 7.900 & 28.993 \\
Milho (1 ${ }^{\mathrm{a}}$ safra) & 0,19 & 614.193 & 114.240 \\
Soja & 1,42 & 469.537 & 84.517 \\
\hline Total & 1,40 & 56.763 & 80.603 \\
\hline
\end{tabular}




\subsubsection{Amazonas}

TABELA 20: Produção-Unidade da Federação: Amazonas - Dezembro 2007

\begin{tabular}{|c|c|c|c|}
\hline Produto (t) & $\begin{array}{l}\text { İndice de } \\
\text { resíduos }\end{array}$ & Produção (t) & $\begin{array}{c}\text { Quantidade de } \\
\text { resíduos }(t)\end{array}$ \\
\hline Arroz & 1,49 & 19.478 & 29.022 \\
\hline Café beneficiado & 0,40 & 5.830 & 2.332 \\
\hline Cana de açúcar & 0,28 & 318.021 & 89.046 \\
\hline Castanha do Pará & 0,73 & 9.165 & 6.690 \\
\hline Coco da Bahia & 0,60 & 1.429 & 857 \\
\hline $\begin{array}{l}\text { Feijão ( }\left(^{a} \text { e } 2^{a}\right. \\
\text { safras })\end{array}$ & 3,67 & 6.455 & 23.690 \\
\hline Mandioca & 0,19 & 698.796 & 129.976 \\
\hline $\begin{array}{c}\text { Madeira/ tora } \\
\text { lenha }\end{array}$ & 0,18 & 1.574 .805 & 283.465 \\
\hline Milho ( $1^{a}$ safra) & 1,42 & 37.069 & 52.638 \\
\hline Soja & 1,40 & 5.138 & 7.193 \\
\hline Total & & 2.676 .186 & 624.910 \\
\hline
\end{tabular}




\subsubsection{Roraima}

TABELA 21: Produção-Unidade da Federação: Roraima - Dezembro 2007

\begin{tabular}{cccc}
\hline Produto (t) & $\begin{array}{c}\text { Índice de } \\
\text { resíduos }\end{array}$ & Produção (t) & $\begin{array}{c}\text { Quantidade de } \\
\text { resíduos (t) }\end{array}$ \\
\hline Arroz & 1,49 & 106.000 & 157.940 \\
Cana de açúcar & 0,28 & 1.290 & 361 \\
Castanha do Pará & 0,73 & 91 & 66 \\
$\begin{array}{c}\text { Feijão (1 }{ }^{\mathrm{a}} \text { e 2 } \\
\text { safras) }\end{array}$ & 3,67 & 658 & 2.415 \\
$\begin{array}{c}\text { Mandioca } \\
\text { Madeira/ tora } \\
\text { lenha }\end{array}$ & 0,19 & 77.190 & 14.357 \\
$\begin{array}{c}\text { Milho (1 } \\
\text { a safra) }\end{array}$ & 0,18 & 111.690 & 20.104 \\
Soja & 1,42 & 12.800 & 18.176 \\
\hline Total & 1,40 & 30.800 & 43.120 \\
\hline
\end{tabular}




\subsubsection{Pará}

Tabela 22: Produção-Unidade da Federação: Pará - Dezembro 2007

\begin{tabular}{cccc}
\hline Produto (t) & $\begin{array}{c}\text { Índice de } \\
\text { resíduos }\end{array}$ & Produção (t) & $\begin{array}{c}\text { Quantidade de } \\
\text { resíduos (t) }\end{array}$ \\
\hline Arroz & 1,49 & 389.971 & 581.057 \\
Cana de açúcar & 0,28 & 677.844 & 189.796 \\
Castanha do Pará & 0,73 & 5.291 & 3.862 \\
$\begin{array}{c}\text { Feijão (19 e 2a } \\
\text { safras) }\end{array}$ & 3,67 & 63.193 & 231.918 \\
$\begin{array}{c}\text { Mandioca } \\
\text { Madeira/ tora } \\
\text { lenha } \\
\text { Milho }\end{array}$ & 0,19 & 5.216 .955 & 970.354 \\
Soja & 0,18 & 6.157 .301 & 1.108 .314 \\
Total & 1,42 & 562.081 & 798.155 \\
& 1,40 & 153.943 & 215.520 \\
\hline & & 13.354 .890 & $\mathbf{4 . 1 7 5 . 9 6 3}$
\end{tabular}




\subsubsection{Amapá}

TABELA 23: Produção-Unidade da Federação: Amapá - Dezembro 2007

\begin{tabular}{cccc}
\hline Produto (t) & $\begin{array}{c}\text { Índice de } \\
\text { resíduos }\end{array}$ & Produção (t) & $\begin{array}{c}\text { Quantidade de } \\
\text { resíduos (t) }\end{array}$ \\
\hline Arroz & 1,49 & 2.184 & 3.254 \\
Cana de açúcar & 0,28 & 2.205 & 617 \\
Castanha do Pará & 0,73 & 917 & 669 \\
$\begin{array}{c}\text { Feijão (1a e 2a } \\
\text { safras) }\end{array}$ & 3,67 & 1.100 & 4.037 \\
$\begin{array}{c}\text { Mandioca } \\
\text { Madeira/ tora } \\
\text { lenha } \\
\text { Milho }\end{array}$ & 0,19 & 92.500 & 17.205 \\
Total & 0,18 & 120.570 & 21.703 \\
& 1,42 & 1.900 & 2.698 \\
\hline
\end{tabular}




\subsubsection{TOCANTINS}

TABELA 24: Produção-Unidade da Federação: Tocantins - Dezembro 2007

\begin{tabular}{cccc}
\hline Produto (t) & $\begin{array}{c}\text { Índice de } \\
\text { resíduos }\end{array}$ & Produção (t) & $\begin{array}{c}\text { Quantidade de } \\
\text { resíduos (t) }\end{array}$ \\
\hline Arroz & 1,49 & 364.988 & 543.832 \\
Cana-de-açúcar & 0,28 & 202.870 & 56.804 \\
$\begin{array}{c}\text { Feijão (1a e } 2^{\mathrm{a}} \\
\text { safras) }\end{array}$ & 3,67 & 8.142 & 29.881 \\
$\begin{array}{c}\text { Mandioca } \\
\text { Madeira/ tora } \\
\text { lenha } \\
\text { Milho }\end{array}$ & 0,19 & 352.504 & 65.566 \\
Soja & 0,18 & 435.539 & 78.397 \\
Total & 1,42 & 146.517 & 208.054 \\
& 1,40 & 665.392 & 931.549 \\
\hline
\end{tabular}


A TAB. 25 mostra o total das produções agrícolas escolhidas e os resíduos gerados por elas na região Norte, por estado.

TABELA 25: Produção total da região Norte das culturas escolhidas Dezembro 2007

\begin{tabular}{ccc}
\hline Estado & $\begin{array}{c}\text { Produção Anual } \\
(\mathbf{t})\end{array}$ & $\begin{array}{c}\text { Quantidade de } \\
\text { resíduos } \\
\text { Anual(t) }\end{array}$ \\
\hline Acre & 1.223 .348 & 368.129 \\
Amapá & 221.376 & 50.184 \\
Amazonas & 4.707 .868 & 624.910 \\
Pará & 20.634 .703 & 4.175 .963 \\
Roraima & 493.479 & 256.540 \\
Tocantins & 1.689 .743 & 1.914 .083 \\
\hline Total & $\mathbf{3 0 . 8 5 7 . 5 9 1}$ & $\mathbf{8 . 7 1 2 . 6 5 5}$
\end{tabular}




\subsection{Região Centro-oeste}

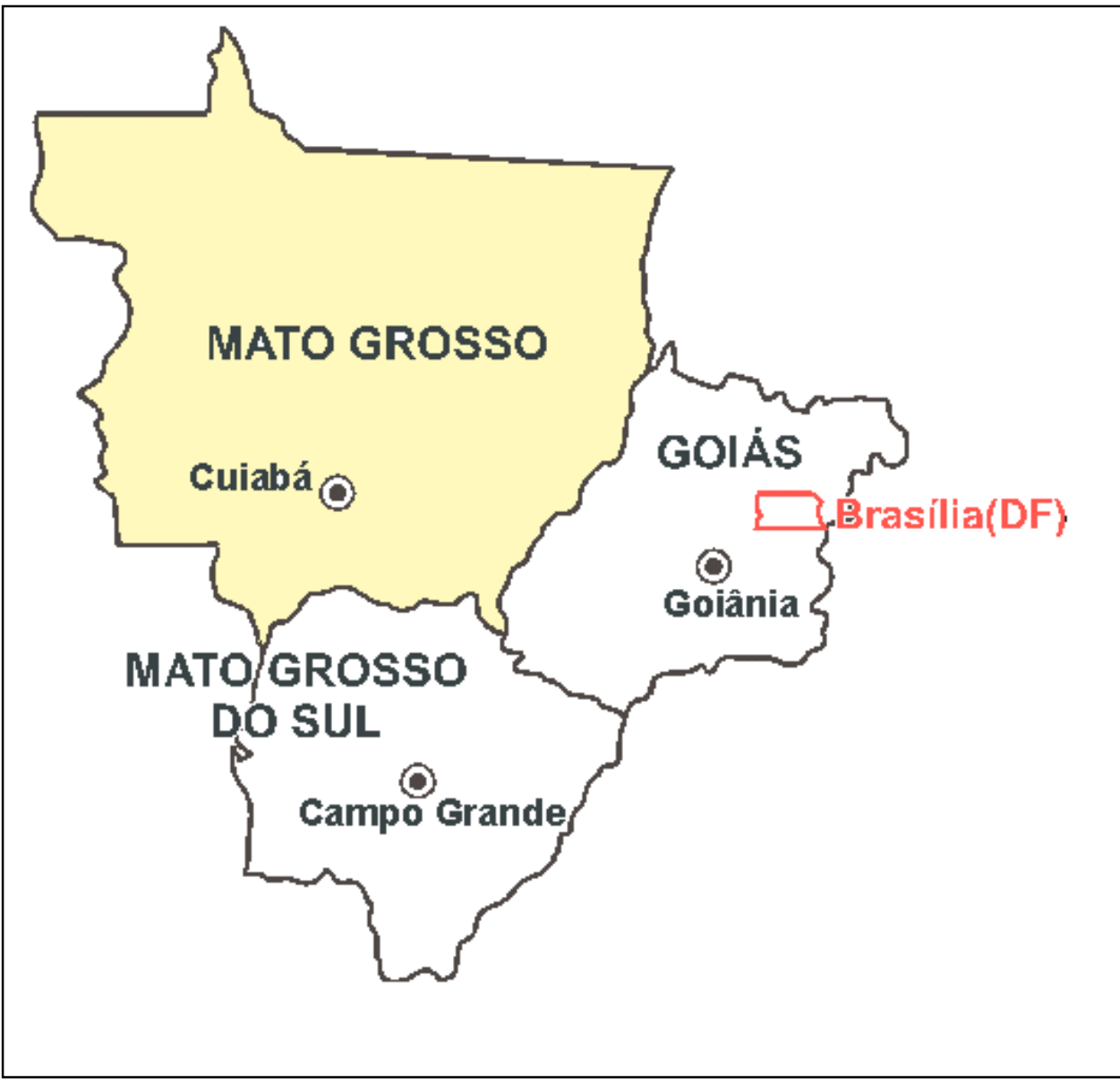

FIGURA 25: Mapa região centro-oeste ${ }^{114}$.

A Região Centro-Oeste é dividida em quatro unidades federativas: Mato Grosso, Mato Grosso do Sul, Goiás e Distrito Federal, onde fica Brasília, a capital do país. Com uma área de 1.606.371,505 km², com 7,23 hab/km² a Região Centro-Oeste é um grande território, sendo a segunda maior região do Brasil em superfície territorial. Por outro lado, é a região menos populosa do país e possui a segunda menor densidade populacional, perdendo apenas para a Região Norte. Por abrigar uma quantidade menor de habitantes, apresenta algumas concentrações urbanas e grandes vazios populacionais. 


\subsubsection{Vegetação}

No Centro-Oeste existem formações vegetais bastante diferentes umas das outras. Ao norte e oeste aparece a Floresta Amazônica, composta por uma vegetação densa e exuberante. A maior parte da região, entretanto, é ocupada pelo cerrado, tipo de savana com gramíneas altas, árvores e arbustos esparsos, de troncos retorcidos, folhas duras e raízes longas, adaptadas à procura de água no subsolo. O cerrado não é uniforme: onde há mais árvores que arbustos, ele é conhecido como cerradão, e no cerrado propriamente dito há menos arbustos e árvores, entre os quais se espalha uma formação contínua de gramíneas.

Em Mato Grosso do Sul, existe os campos limpos, conhecidos pelo nome de campos de Vacaria, que lembram vagamente o pampa gaúcho. A região do Pantanal, sempre alagável quando das cheias de verão, possui uma vegetação típica e muito variada, denominada Complexo do Pantanal. Aí aparecem concentradas quase todas as variedades vegetais do Brasil: florestas, campos e até mesmo a caatinga.

Podem ser identificadas ainda as matas galerias em alguns trechos do cerrado, que se caracterizam por serem densas apenas nas margens dos cursos d'água ao longo dos quais se desenvolvem e cuja umidade as mantém. A floresta tropical que existia na região está praticamente extinta.

\subsubsection{Clima}

O clima da região Centro-Oeste do Brasil é tropical, quente e chuvoso, sempre presente nos Estados de Mato Grosso, Mato Grosso do Sul e Goiás. A característica mais marcante deste clima quente é a presença de um verão chuvoso, entre os meses de outubro e março, e um inverno seco, entre os meses de maio e setembro.

O noroeste da região, ocupado pela Amazônia, é abrangido pelo clima equatorial, e o restante pelo clima tropical. As temperaturas, são mais altas do que no sul. $\mathrm{O}$ inverno apresenta temperaturas acima de $18^{\circ} \mathrm{C}$; durante o verão, a temperatura pode alcançar temperaturas superiores a $25^{\circ} \mathrm{C}$. Existe declínio sensível de temperatura quando ocorre o fenômeno da friagem, que é a chegada 
de uma massa polar atlântica que através do vale do rio Paraguai, atinge todo o oeste dos Estados de Mato Grosso e Mato Grosso do Sul.

As chuvas, além de concentradas em apenas uma estação do ano, se distribuem irregularmente na região, atingindo-se mais de $2.500 \mathrm{~mm}$ a noroeste de Mato Grosso e reduzindo-se a pouco mais de $1.200 \mathrm{~mm}$ em grande parte do território.

Os meses de verão são úmidos, porque nessa época, a Planície do Pantanal é uma das áreas mais quentes da América do Sul e, por esse motivo, forma um núcleo de baixa pressão que atrai os ventos úmidos conhecidos como alísios de nordeste. A chegada desses ventos corresponde às chuvas fortes que caem na região. O norte da região, de altas temperaturas e grande quantidade de chuvas, engloba características do clima equatorial. No restante da região, o efeito da continentalidade faz com que o clima tropical apareça mais seco, e por conseqüência, a paisagem vegetal revele densidade menor, apresentando-se sob a forma de cerrado.

\subsubsection{Hidrologia}

A Região Centro-Oeste é drenada por muitos rios, agrupados em três grandes bacias hidrográficas:

Bacia Amazônica:, em Mato Grosso, para onde se deslocam rios colossais, como o Xingu, ou rios que formam principais afluentes do rio Amazonas, como o Juruena e o Teles Pires que formam o rio Tapajós;

Bacia do Tocantins-Araguaia, ocupando o norte e o ponto mais a oeste de Goiás e o extremo leste de Mato Grosso;

Bacia Platina, subdividida em suas bacias hidrográficas: a bacia do rio Paraná e a bacia do rio Paraguai, no restante da região.

Com a avaliação das produções agrícolas feitas estado por estado da região Centro-Oeste foi possível elaborar as TAB de 26 a 29, onde são mostradas as produções anuais por estado e a quantidade de resíduo produzida. 
4.4.4 Avaliação da produção de resíduos da região Centro-Oeste por estado.

\subsubsection{Mato Grosso do Sul}

Tabela 26: Produção-Unidade da Federação: Mato Grosso do Sul - Dezembro 2007

\begin{tabular}{|c|c|c|c|}
\hline Produto (t) & $\begin{array}{l}\text { İndice de } \\
\text { resíduos }\end{array}$ & Produção (t) & $\begin{array}{l}\text { Quantidade de } \\
\text { resíduos (t) }\end{array}$ \\
\hline Algodão herbáceo & 2,45 & 183.216 & 448.879 \\
\hline Arroz & 1,49 & 207.899 & 309.770 \\
\hline Café em grão & 0,40 & 2.684 & 1.074 \\
\hline Cana-de-açúcar & 0,28 & 15.839 .993 & 4.435.198 \\
\hline $\begin{array}{l}\text { Feijão }\left(1^{a} \text { e } 2^{a}\right. \\
\text { safras })\end{array}$ & 3,67 & 23.754 & 87.177 \\
\hline Mandioca & 0,19 & 480.559 & 89.384 \\
\hline $\begin{array}{c}\text { Madeira/ tora } \\
\text { lenha }\end{array}$ & 0,18 & 253.350 & 45.603 \\
\hline Milho ( $1^{a}$ safra) & 1,42 & 2.972 .221 & 4.220 .554 \\
\hline Soja & 1,40 & 4.846 .031 & 6.784 .443 \\
\hline Total & & 24.809 .707 & 16.422 .082 \\
\hline
\end{tabular}




\subsubsection{MATO Grosso}

Tabela 27: Produção-Unidade da Federação: Mato Grosso - Dezembro 2007

\begin{tabular}{cccc}
\hline Produto $(\mathbf{t})$ & $\begin{array}{c}\text { İndice de } \\
\text { resíduos }\end{array}$ & Produção (t) & $\begin{array}{c}\text { Quantidade de } \\
\text { resíduos (t) }\end{array}$ \\
\hline Algodão herbáceo & 2,45 & 2.204 .459 & 5.400 .925 \\
Arroz & 1,49 & 707.167 & 1.053 .679 \\
Amendoim & 1,08 & 9.167 & 9.900 \\
Cana de açúcar & 0,28 & 15.000 .327 & 4.200 .092 \\
$\begin{array}{c}\text { Feijão (1a e } 2^{\mathrm{a}} \\
\text { safras) }\end{array}$ & 3,67 & 60.283 & 221.239 \\
$\begin{array}{c}\text { Mandioca } \\
\text { Madeira/ tora } \\
\text { lenha }\end{array}$ & 0,19 & 549.695 & 102.243 \\
$\begin{array}{c}\text { Milho (1a safra) } \\
\text { Soja }\end{array}$ & 0,18 & 1.763 .403 & 317.413 \\
Total & 1,42 & 6.083 .789 & 8.638 .980 \\
\hline
\end{tabular}




\subsubsection{GoIÁs}

Tabela 28: Produção-Unidade da Federação: Goiás - Dezembro 2007

\begin{tabular}{cccc}
\hline Produto $(\mathbf{t})$ & Índice de resíduos & Produção (t) & $\begin{array}{c}\text { Quantidade de } \\
\text { resíduos (t) }\end{array}$ \\
\hline Algodão herbáceo & 2,45 & 296.553 & 726.555 \\
Arroz & 1,49 & 248.828 & 370.754 \\
Amendoim & 1,08 & 3.955 & 4.271 \\
Cana de açúcar & 0,28 & 22.387 .847 & 6.268 .597 \\
$\begin{array}{c}\text { Feijão (1 }{ }^{\text {a }} \text { e } 2^{\mathrm{a}} \\
\text { safras) }\end{array}$ & 3,67 & 253.668 & 930.962 \\
Mandioca & 0,19 & 466.520 & 86.773 \\
Madeira/ tora lenha & 0,18 & 351.205 & 63.217 \\
Milho (1 ${ }^{\text {a }}$ safra) & 1,42 & 4.169 .313 & 5.920 .424 \\
Soja & 1,40 & 5.937 .727 & 8.312 .818 \\
\hline Total & & 34.115 .616 & $\mathbf{2 2 . 6 8 4 . 3 7 1}$ \\
\hline
\end{tabular}




\subsubsection{DISTRITO FEDERAL}

Tabela 29: Produção-Unidade da Federação: D. Federal - Dezembro 2007

\begin{tabular}{cccc}
\hline Produto $(\mathbf{t})$ & Índice de resíduos & Produção (t) & $\begin{array}{c}\text { Quantidade de } \\
\text { resíduos (t) }\end{array}$ \\
\hline Arroz & 1,49 & 789 & 1.176 \\
$\begin{array}{c}\text { Café em grão } \\
\text { Feijão (1 }{ }^{\text {a }} \text { e } 2^{\mathrm{a}} \\
\text { safras) }\end{array}$ & 0,40 & 884 & 354 \\
Mandioca & 3,67 & 45.365 & 166.490 \\
Milho (1 ${ }^{\text {a }}$ safra) & 0,19 & 14.398 & 2.678 \\
Soja & 1,42 & 264.436 & 375.499 \\
Total & 1,40 & 142.720 & 199.808 \\
\hline
\end{tabular}

A tabela 30 mostra o total das produções agrícolas escolhidas e os resíduos gerados por elas na região Centro Oeste, por estado.

Tabela 30: Produção total da região Centro Oeste das culturas escolhidas- Dezembro 2007

\begin{tabular}{ccc}
\hline Estado & $\begin{array}{c}\text { Produção Anual } \\
(\mathbf{t})\end{array}$ & $\begin{array}{c}\text { Quantidade de } \\
\text { resíduos Anual(t) }\end{array}$ \\
\hline Mato Grosso do Sul & 24.809 .707 & 16.422 .082 \\
Mato Grosso & 41.653 .377 & 41.329 .592 \\
Goiás & 34.115 .616 & 22.684 .371 \\
Distrito Federal & 468.592 & 746.004 \\
\hline Total & $\mathbf{1 0 1 . 0 4 7 . 2 9 2}$ & $\mathbf{8 1 . 1 8 2 . 0 4 9}$ \\
\hline
\end{tabular}




\subsection{Região Sudeste.}

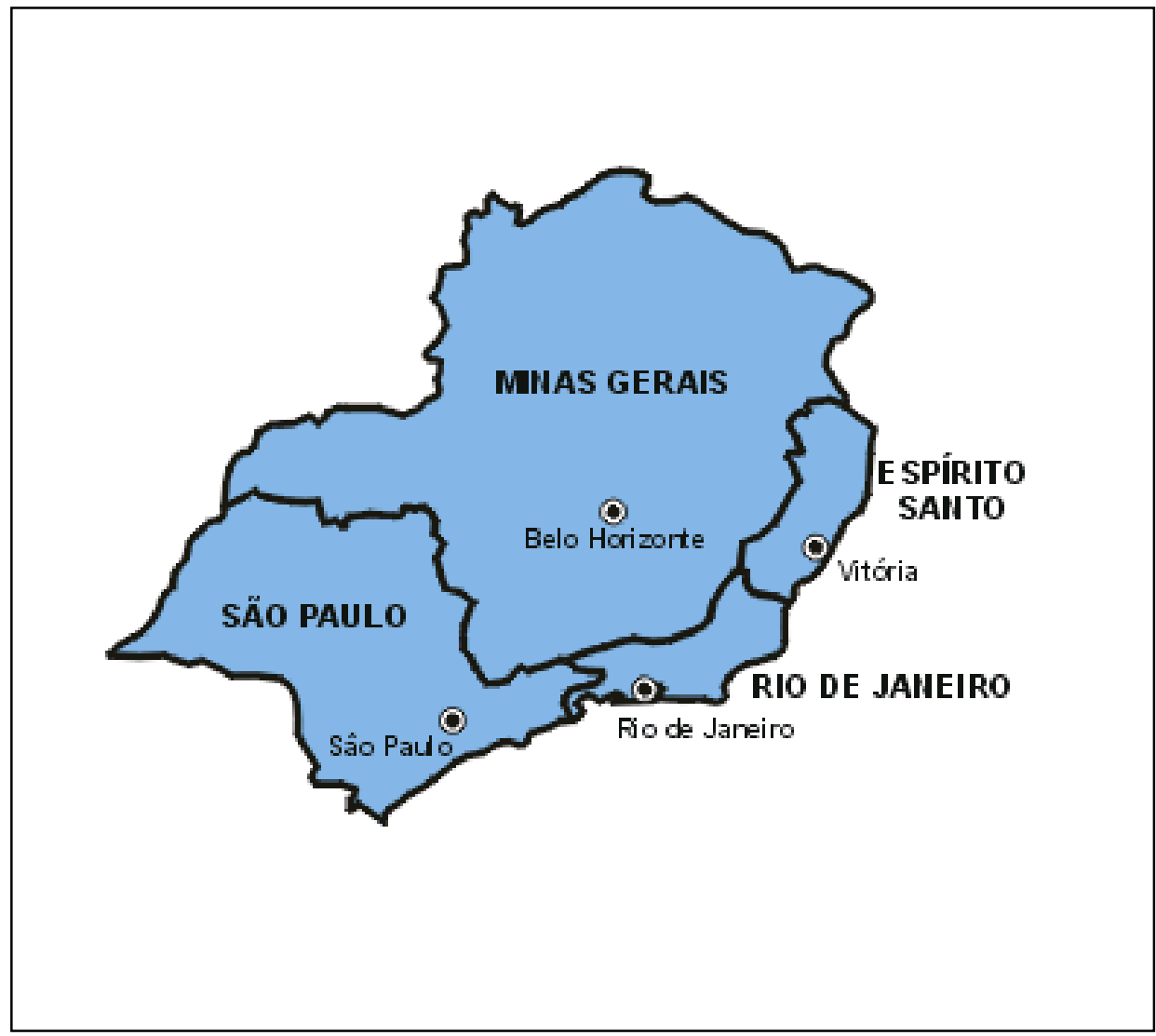

FIGURA 26: Mapa região Sudeste ${ }^{114}$.

A Região Sudeste do Brasil é composta pelos estados de São Paulo, Minas Gerais, Rio de Janeiro e Espírito Santo. Esta região é por excelência uma terra de transição entre a região Nordeste e a região Sul e ocupa uma área de $924.266 \mathrm{Km}^{2}$.

Região mais populosa e rica do Brasil, o Sudeste ocupa $10,85 \%$ do território brasileiro. Altamente urbanizada $(90,5 \%)$, abriga as três metrópoles mais importantes do país, as cidades de São Paulo, Rio de Janeiro e Belo Horizonte, além de ser o maior colégio eleitoral do país, apresentando no ano de 2005, pouco mais de 78 milhões de habitantes, o que equivale a quase $42 \%$ da população brasileira. 


\subsubsection{Vegetação}

A vegetação predominante é a Mata Atlântica, mas novamente há exceções como a Mata de Araucária no sul de São Paulo e nas regiões serranas, e a Caatinga no norte de Minas Gerais.

O norte de Minas Gerais possui características do Nordeste, fazendo parte da bacia do Rio São Francisco e era território do Estado de Pernambuco até o início do século XIX.

O interior de São Paulo, notadamente a região entre os rios Tietê e o Paranapanema (região de Bauru, Marília, Itapeva, Presidente Prudente) é região de transição entre o Sudeste e o Sul, possuindo características destas duas regiões.

Hoje em dia restam pequenos trechos da Mata Atlântica porque a maioria da mata foi substituída por áreas urbanas, pastagens e plantações.

No litoral, nas partes mais alagadas encontramos os manguezais.

A variedade de tipos de clima permite deduzir que primitivamente existiu uma variedade de tipos de vegetação, hoje em grande parte devastada, devido à expansão agrícola.

A floresta tropical constitui a formação dominante, mas seu aspecto varia muito. Ela é rica e exuberante nas encostas voltadas para o oceano, conhecida como Mata Atlântica, onde a umidade é maior, favorecendo o aparecimento de árvores mais altas, muitos cipós, epífitas e inúmeras palmáceas; encontra-se quase totalmente devastada, exceto nas encostas mais íngremes. No interior do continente, essa floresta apresenta-se menos densa, pois ocorre em áreas de clima mais seco; aparece somente em manchas, pois já está quase inteiramente devastada.

Em algumas áreas do interior há a ocorrência de matas galerias ou ciliares, que se desenvolvem ao longo das margens dos rios, mais úmidas. Nas áreas tipicamente tropicais do Sudeste, onde predominam solos impermeáveis, ganha destaque a formação conhecida como cerrado, constituída de pequenas árvores, arbustos de galhos retorcidos e vegetação rasteira. A região apresenta pequenos trechos cobertos de caatinga no norte de Minas Gerais. As áreas mais 
altas das Serras e Planaltos do Leste e Sudeste, ao sul, de clima mais suave, são ocupadas por uma ou outra espécie do que foi um dia a floresta subtropical ou Mata de Araucárias. Em extensões também reduzidas do planalto aparecem trechos de formações campestres: os campos limpos, ao sul do estado de São Paulo, e os campos serranos, ao sul de Minas Gerais. Ao longo do litoral, faz-se presente a vegetação típica das praias.

\subsubsection{Clima}

O clima dessa região é bastante diversificado no que diz respeito à temperatura, em função de três fatores principais: a posição latitudinal, a topografia acidentada e a influência dos sistemas de circulação perturbada. Corresponde a uma faixa de transição entre climas quentes das baixas latitudes e os climas mesotérmicos das latitudes médias, mas suas características mais fortes são de clima tropical. O norte de Minas Gerais possui clima semi-árido e faz parte do Polígono das Secas. Nas áreas mais elevadas do planalto atlântico,ocorre o clima tropical de altitude, que tem temperaturas mais baixas que as demais áreas.

A Região Sudeste apresenta os climas tropical, tropical de altitude, subtropical e semi-árido.

O clima tropical predomina nas baixadas litorâneas de Espírito Santo e Rio de Janeiro, norte de Minas Gerais e oeste paulista. Apresenta temperaturas elevadas (média anual de $22^{\circ} \mathrm{C}$ ) e duas estações definidas: uma chuvosa, que corresponde ao verão, e outra seca, que corresponde ao inverno.

O clima tropical de altitude, que ocorre nos trechos mais elevados do relevo, caracteriza-se por temperaturas mais amenas (média anual de $18^{\circ} \mathrm{C}$ ).

O clima subtropical, que aparece no sul do estado de São Paulo, é marcado por chuvas bem distribuídas durante o ano (temperaturas médias anuais em torno de $16^{\circ} \mathrm{C}$ a $17^{\circ} \mathrm{C}$ ) e por uma grande amplitude térmica. Temos ainda, no norte de Minas Gerais, o clima semi-árido, mais quente e menos úmido, apresentando estação seca anual de 5 meses ou até mais nos vales dos rios São Francisco e Jequitinhonha. 
No Sudeste, como em qualquer região, as temperaturas sofrem a determinante influência da posição geográfica, ou seja, da latitude, do relevo e da altitude e também da maritimidade. Desta forma, as regiões do Vale do Jequitinhonha e do Vale do Rio Doce ambas no norte de Minas Gerais e norte do Espírito Santo, localizadas em áreas de baixas latitudes e altitudes modestas, têm clima mais quente. Já a Serra do Mar apresenta a maior umidade da região, pois barra a passagem dos ventos vindos do Atlântico, carregados de umidade, chovendo apenas nas vertentes orientais. A costa também é naturalmente mais úmida, por influência da maritimidade.

As menores temperaturas da região são registradas nos picos da Serra da Mantiqueira, localizados entre MG/SP, MG/RJ e MG/ES, que tem altitudes próximas de $3000 \mathrm{~m}$ e consequentemente estão sujeitos a nevadas.

\subsubsection{Hidrologia}

A região apresenta vários rios importantes, como o Rio Tietê, Rio Paraíba do Sul, Rio Paraná, Rio Piracicaba, Rio Doce.

A região também apresenta a nascente do rio São Francisco, na Serra da Canastra em Minas Gerais.

Os rios da região são utilizados para navegação, mas principalmente para a produção de energia elétrica através de usinas hidrelétricas. Nessa região está localizada a usina hidrelétrica de Furnas.

Devido a suas características de relevo, predominam na região os rios de planalto, naturalmente encachoeirados. Entre as várias bacias hidrográficas, merecem destaque:

Bacia do Paraná - O rio principal é formado pela junção dos rios Paranaíba e Grande. Nessa bacia se localizam algumas das maiores hidrelétricas do país, tanto no rio Paraná (Urubupungá e Itaipu) como nos rios Paranaíba (Cachoeira Dourada e São Simão) e Grande (Furnas e Volta Grande). 
Bacia do São Francisco - O principal rio desta região nasce em Minas Gerais, na Serra da Canastra, atravessa a Bahia e alcança Pernambuco, Alagoas e Sergipe, no Nordeste. Recebendo alguns grandes afluentes e outros menores, que chegam inclusive a secar (rios temporários), o São Francisco tem alta importância regional, por oferecer transporte, alimentação, energia elétrica e irrigação.

No seu alto curso, que vai da nascente a Pirapora (Minas Gerais), o São Francisco é acidentado e não-navegável, oferecendo, por outro lado, alto potencial hidrelétrico. A Usina Hidrelétrica de Três Marias foi aí construída a fim de regularizar o curso do rio, fornecer energia elétrica e ampliar seu trecho navegável, através de comportas que fazem subir o nível das águas. Já no médio curso, que se estende de Pirapora e Juazeiro (estado da Bahia), o rio é inteiramente navegável. O baixo curso do São Francisco localiza-se inteiramente na Região Nordeste.

\footnotetext{
Bacias do Leste - São um conjunto de bacias secundárias de diversos rios que descem das serras litorâneas para o Atlântico, merecendo destaque as bacias dos rios Pardo, Doce e Jequitinhonha, em Minas Gerais, e Paraíba do Sul, em São Paulo e Rio de Janeiro.
}

Bacias do Sudeste-Sul — A Região Sudeste é drenada também por estas bacias, destacando-se a do rio Ribeira do Iguape, no estado de São Paulo.

Com a avaliação das produções agrícolas feitas estado por estado da região Centro-Oeste foi possível elaborar as TAB. de 31 a 34 onde são mostradas as produções anuais por estado e a quantidade de resíduo produzida. 
4.5.4 Avaliação da produção de resíduos da região Sudeste por estado.

\subsubsection{Minas Gerais}

Tabela 31: Produção-Unidade da Federação: Minas Gerais - Dezembro 2007

\begin{tabular}{cccc}
\hline Produto $(\mathbf{t})$ & $\begin{array}{c}\text { İndice de } \\
\text { resíduos }\end{array}$ & Produção $(\mathbf{t})$ & $\begin{array}{c}\text { Quantidade de } \\
\text { resíduos (t) }\end{array}$ \\
\hline Algodão herbáceo & 2,45 & 89.649 & 219.640 \\
Amendoim & 1,08 & 6.281 & 6.752 \\
Arroz & 1,49 & 183.419 & 273.294 \\
Café em grão & 0,40 & 987.292 & 444.281 \\
Cana de açúcar & 0,28 & 38.741 .094 & 10.847 .506 \\
Coco da baia & 0,6 & 21.939 & 13.163 \\
Feijão & 3,67 & 480.863 & 1.764 .767 \\
Mandioca & 0,19 & 904.086 & 171.776 \\
Milho & 1,42 & 6.066 .077 & 8.613 .829 \\
Soja & 1,40 & 2.417 .996 & 3.385 .194 \\
Trigo & 1,42 & 51.253 & 72.779 \\
Total & & $\mathbf{4 9 . 9 4 9 . 9 4 9}$ & $\mathbf{2 5 . 8 1 2 . 9 8 4}$ \\
\hline
\end{tabular}




\subsubsection{Espirito Santo}

Tabela 32: Produção-Unidade da Federação: Espírito Santo - Dezembro 2007

\begin{tabular}{cccc}
\hline Produto (t) & $\begin{array}{c}\text { Índice de } \\
\text { resíduos }\end{array}$ & Produção (t) & $\begin{array}{c}\text { Quantidade de } \\
\text { resíduos (t) }\end{array}$ \\
\hline Arroz & 1,49 & 8.049 & 11.993 \\
Café em grão & 0,40 & 617.538 & 277.892 \\
Cana de açúcar & 0,28 & 4.436 .412 & 1.242 .195 \\
Coco da baia & 0,6 & 84.585 & 50.751 \\
Feijão & 3,67 & 16.577 & 60.838 \\
Mandioca & 0,19 & 295.676 & 56.178 \\
Milho & 1,42 & 91.841 & 130.414 \\
\hline Total & & $\mathbf{5 . 5 5 0 . 6 7 8}$ & $\mathbf{1 . 8 3 0 . 2 6 2}$
\end{tabular}




\subsubsection{Rio de Janeiro}

Tabela 33: Produção-Unidade da Federação: Rio de Janeiro - Dezembro 2007

\begin{tabular}{cccc}
\hline Produto (t) & $\begin{array}{c}\text { Índice de } \\
\text { resíduos }\end{array}$ & Produção (t) & $\begin{array}{c}\text { Quantidade de } \\
\text { resíduos (t) }\end{array}$ \\
\hline Arroz & 1,49 & 7.644 & 11.390 \\
Café em grão & 0,40 & 15.734 & 7.080 \\
Cana de açúcar & 0,28 & 5.965 .446 & 1.670 .325 \\
Coco da baia & 0,6 & 38.973 & 23.384 \\
Feijão & 3,67 & 5.560 & 20.405 \\
Mandioca & 0,19 & 131.533 & 24.991 \\
Milho & 1,42 & 22.631 & 32.136 \\
\hline Total & & 6.187 .521 & $\mathbf{1 . 7 8 9 . 7 1 1}$
\end{tabular}




\subsubsection{São Paulo}

Tabela 34: Produção-Unidade da Federação: São Paulo - Dezembro 2007

\begin{tabular}{|c|c|c|c|}
\hline Produto (t) & $\begin{array}{l}\text { Índice de } \\
\text { resíduos }\end{array}$ & Produção (t) & $\begin{array}{c}\text { Quantidade de } \\
\text { resíduos (t) }\end{array}$ \\
\hline Algodão herbáceo & 2,45 & 118.552 & 290.452 \\
\hline Amendoim & 1,08 & 211.551 & 227.417 \\
\hline Arroz & 1,49 & 87.744 & 130.739 \\
\hline Café em grão & 0,40 & 234.551 & 105.548 \\
\hline Cana de açúcar & 0,28 & 329.095 .578 & 92.146 .762 \\
\hline Coco da baia & 0,6 & 16.879 & 10.127 \\
\hline Feijão & 3,67 & 247.840 & 909.573 \\
\hline Mandioca & 0,19 & 1.026 .732 & 195.079 \\
\hline Milho & 1,42 & 4.190 .573 & 5.950 .614 \\
\hline Soja & 1,40 & 1.243 .833 & 1.741 .366 \\
\hline Trigo & 1,42 & 105.159 & 149.326 \\
\hline Total & & 336.578 .992 & 101.857 .003 \\
\hline
\end{tabular}


A tabela 35 mostra o total das produções agrícolas escolhidas e os resíduos gerados por elas na região Sudeste, por estado.

Tabela 35: Produção total da região Sudeste das culturas escolhidas Dezembro 2007

\begin{tabular}{ccc}
\hline Estado & $\begin{array}{c}\text { Produção Anual } \\
(\mathbf{t})\end{array}$ & $\begin{array}{c}\text { Quantidade de } \\
\text { resíduos } \\
\text { Anual(t) }\end{array}$ \\
\hline Minas Gerais & 49.949 .949 & 25.812 .984 \\
Espírito Santo & 5.550 .678 & 1.830 .262 \\
Rio de Janeiro & 6.187 .521 & 1.789 .711 \\
São Paulo & 336.578 .992 & 101.587 .003 \\
\hline Total & 398.267 .140 & 131.019 .960 \\
\end{tabular}




\subsection{Região Sul.}

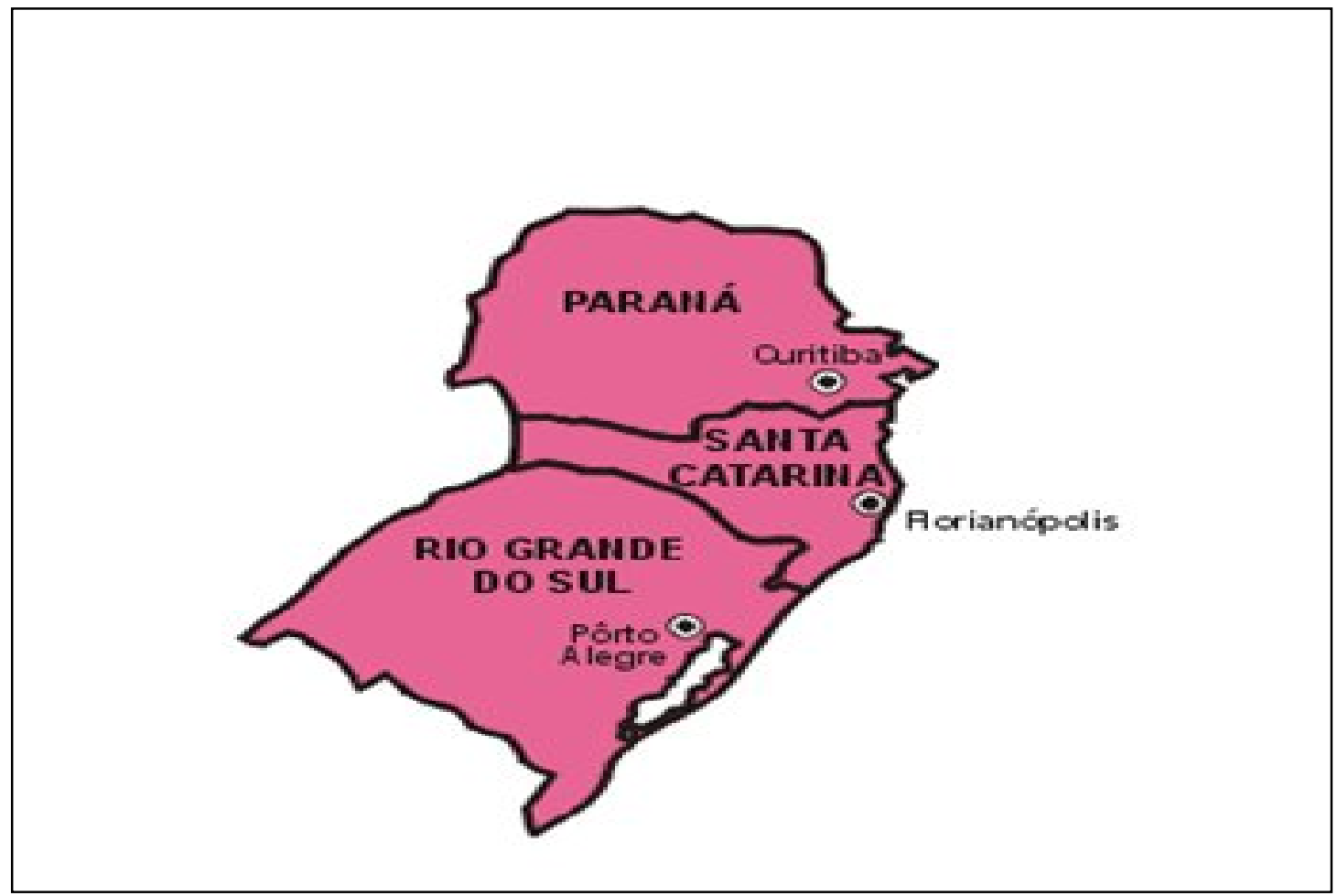

FIGURA 27: Mapa região Sul ${ }^{114}$.

A Região Sul compreende os estados do Paraná, Rio Grande do Sul e Santa Catarina, que juntos totalizam uma superfície de $576.300,8 \mathrm{~km}^{2}$. A Região Sul é a menor das regiões brasileiras e faz parte da região geoeconômica Centro-Sul. É um grande polo turístico, econômico e cultural, com grande influência européia, principalmente de origem italiana e germânica. A Região Sul apresenta altos índices sociais em vários aspectos: possui o maior IDH do Brasil, 0,807 , e a segunda maior renda per capita do país, $13.208,00$ reais, atrás apenas da Região Sudeste. A região é também a mais alfabetizada, $93,7 \%$ da população.

Faz fronteiras com o Uruguai ao sul, com a Argentina e com o Paraguai ao oeste, com a Região Centro-Oeste e com a Região Sudeste do Brasil ao norte e com o Oceano Atlântico ao leste. 


\subsubsection{Vegetação}

A Mata de Araucárias, bastante devastada e da qual só restam alguns trechos, aparece nas partes mais elevadas dos planaltos do Rio Grande do Sul, Paraná e Santa Catarina, na forma de manchas entre outras formações vegetais. A Araucaria angustifolia (pinheiro-do-paraná) adapta-se mais facilmente às baixas temperaturas, comuns nas partes mais altas do relevo, e ao solo de rocha mista, arenito e basalto, que se concentra no Planalto Arenito-basáltico, no interior da região.

Desta mata são extraídos principalmente o pinheiro-do-paraná e a imbuia, utilizados em marcenaria, e a erva-mate, cujas folhas são empregadas no preparo do chimarrão.

Além dessa mata, a Serra do Mar, muito úmida devido à proximidade com o Oceano Atlântico, favorece o desenvolvimento da mata tropical úmida da encosta, ou Mata Atlântica, muito densa e com grande variedade de espécies, inicia-se no Nordeste e continua pelo Sudeste até chegar ao Sul.

A Mata de Araucárias, que foi o panorama vegetal típico da região, aparece atualmente apenas em trechos. A devastação iniciou-se no final do Império, devido a concessões feitas pelo governo à abertura de estradas de ferro, e agravou-se com a atividade madeireira.No norte e oste do Paraná, as poucas manchas de floresta tropical estão praticamente destruídas, devido à expansão agrícola. Nos últimos anos, tem-se tentado implantar uma política de reflorestamento.

A Região Sul é ocupada também por vastas extensões de terra de campos limpos, conhecidos pelo nome de campos meridionais, divididos em duas áreas distintas. A primeira corresponde aos campos dos planaltos, que ocorrem em manchas desde o Paraná até o norte do Rio Grande do Sul. A segunda área, os campos da campanha, é mais extensa e localiza-se inteiramente no Rio Grande do Sul, em uma região conhecida como Campanha Gaúcha ou pampa. É a vegetação natural das coxilhas e aparece como uma camada de ervas rasteiras que assim constitui a melhor paisagem natural do Brasil. 
Finalmente, junto ao litoral, merece destaque a vegetação costeira de mangues, praias e restingas, que se assemelham às de outras regiões do Brasil.

\subsubsection{Clima}

No Brasil, país predominantemente tropical, somente a Região Sul é dominada pelo clima subtropical (um clima de transição entre o tropical predominante no Brasil e o temperado, predominante na Argentina), ou seja, o clima típico desta região é mais frio em comparação ao clima tropical, e é onde são registradas as mais baixas temperaturas do país. Nesse clima, as médias variam de $12^{\circ} \mathrm{C}$ a $21^{\circ} \mathrm{C}$ e o inverno costuma ser bastante frio para os padrões brasileiros, com geadas freqüentes em quase todas as áreas, e em locais de altitudes mais elevadas, queda de neve. As estações do ano apresentam-se bastante diferenciadas e a amplitude térmica anual é relativamente alta. As chuvas, em quase toda a região, distribuem-se com relativa regularidade pelo ano inteiro mas pode-se encontrar também características de tropicalidade nas baixadas litorâneas do Paraná e Santa Catarina, onde as médias térmicas são superiores a $20^{\circ} \mathrm{C}$ e as chuvas caem principalmente no verão.

Os ventos também afetam as temperaturas. No verão, sopram os ventos alísios vindos do Sudeste, que por serem quentes e úmidos, provocam altas temperaturas, seguidas de fortes chuvas; no inverno, as frentes frias são geralmente seguidas de massas de ar vindas do Pólo Sul e trazem um vento frio chamado de minuano ou pampeiro.

Com a avaliação das produções agrícolas feitas estado por estado da região Sul foi possível elaborar as $T A B$ de 36 a 38 onde são mostradas as produções anuais por estado e a quantidade de resíduo produzida. 
4.6.3 Avaliação da produção de resíduos da região Sul por estado.

\subsubsection{Paraná}

Tabela 36: Produção-Unidade da Federação: Paraná - Dezembro 2007

\begin{tabular}{cccc}
\hline Produto (t) & $\begin{array}{c}\text { Índice de } \\
\text { resíduos }\end{array}$ & Produção (t) & $\begin{array}{c}\text { Quantidade de } \\
\text { resíduos (t) }\end{array}$ \\
\hline Algodão herbáceo & 2,45 & 25.903 & 63.462 \\
Arroz & 1,49 & 174.258 & 259.644 \\
Café em grão & 0,40 & 97.389 & 43.825 \\
Cana de açúcar & 0,28 & 45.887 .548 & 12.848 .513 \\
Feijão & 3,67 & 766.792 & 2.814 .127 \\
Madeira & 0,18 & 3.482 .962 & 626.933 \\
tora/lenha & 0,19 & 3.365 .003 & 639.351 \\
Mandioca & 1,42 & 14.258 .086 & 20.246 .482 \\
Milho & 1,40 & 11.876 .790 & 16.627 .506 \\
Soja & 1,42 & 1.927 .216 & 2.736 .647 \\
Trigo & & $\mathbf{8 1 . 8 6 1 . 9 4 7}$ & $\mathbf{5 6 . 9 0 6 . 4 9 0}$ \\
\hline Total & & & \\
\hline & & & \\
\hline
\end{tabular}




\subsubsection{Santa Catarina}

Tabela 37: Produção-Unidade da Federação: Santa Catarina - Dezembro 2007

\begin{tabular}{cccc}
\hline Produto (t) & $\begin{array}{c}\text { Índice de } \\
\text { resíduos }\end{array}$ & Produção (t) & $\begin{array}{c}\text { Quantidade de } \\
\text { resíduos (t) }\end{array}$ \\
\hline Arroz & 1,49 & 1.038 .438 & 1.547 .273 \\
Amendoim & 1,08 & 411 & 442 \\
Cana de açúcar & 0,28 & 734.562 & 205.677 \\
Feijão & 3,67 & 214.924 & 788.771 \\
Madeira & 0,18 & 2.176 .939 & 391.849 \\
tora/lenha & 0,19 & 633.216 & 120.311 \\
Mandioca & 1,42 & 3.793 .364 & 5.386 .577 \\
Milho & 1,40 & 1.111 .456 & 1.556 .038 \\
Soja & 1,42 & 203.334 & 288.734 \\
Trigo & & 9.906 .644 & 10.285 .673
\end{tabular}




\subsubsection{Rio Grande do Sul}

Tabela 38: Produção-Unidade da Federação: R. G. do Sul - Dezembro 2007

\begin{tabular}{cccc}
\hline Produto $(\mathbf{t})$ & $\begin{array}{c}\text { İndice de } \\
\text { resíduos }\end{array}$ & Produção (t) & $\begin{array}{c}\text { Quantidade de } \\
\text { resíduos (t) }\end{array}$ \\
\hline Arroz & 1,49 & 6.340 .136 & 9.446 .803 \\
Amendoim & 1,08 & 6.985 & 7.509 \\
Cana de açúcar & 0,28 & 1.426 .978 & 399.554 \\
Feijão & 3,67 & 142.086 & 521.456 \\
Madeira & 0,18 & 1.514 .090 & 272.536 \\
tora/lenha & 0,19 & 1.371 .895 & 260.660 \\
Mandioca & 1,42 & 5.969 .118 & 8.476 .148 \\
Milho & 1,40 & 9.929 .005 & 13.900 .607 \\
Soja & 1,42 & 1.723 .007 & 2.446 .670 \\
Trigo & & $\mathbf{2 8 . 4 2 3 . 3 0 0}$ & $\mathbf{3 5 . 7 3 1 . 9 4 2}$ \\
\hline Total & &
\end{tabular}


A tabela 39 mostra o total das produções agrícolas escolhidas e os resíduos gerados por elas na região Sul, por estado.

Tabela 39: Produção total da região Sul das culturas escolhidas - Dezembro 2007

\begin{tabular}{ccc}
\hline Estado & $\begin{array}{c}\text { Produção Anual } \\
(\mathbf{t})\end{array}$ & $\begin{array}{c}\text { Quantidade de } \\
\text { resíduos } \\
\text { Anual(t) }\end{array}$ \\
\hline Paraná & 81.861 .947 & 56.906 .490 \\
Santa Catarina & 9.906 .644 & 10.285 .673 \\
R. G. do Sul & 28.423 .300 & 35.731 .942 \\
\hline Total & $\mathbf{1 2 6 . 5 3 9 . 0 1 2}$ & $\mathbf{1 0 2 . 9 2 4 . 1 0 5}$ \\
\hline
\end{tabular}




\subsection{Avaliação do potencial de produção de hidrogênio nas diferentes regiões brasileiras a partir da biomassa.}

Quantidade de hidrogênio produzido (t/ano) (a): Para se obter a quantidade de hidrogênio total que poderá ser gerada nas diferentes regiões foram efetuados cálculos levando-se em conta a quantidade de resíduos produzidos de biomassa na região em toneladas por ano e a porcentagem média de hidrogênio obtido por meio do processo de gaseificação destes resíduos e posterior reforma a vapor dos gases produzidos.

$$
\text { (a) }=\text { resíduo }(\text { t/ano }) \times 12 \%
$$

Para se fazerem os cálculos da produção de hidrogênio para uso em células a combustível para a geração de energia elétrica utilizam-se dados em $\mathrm{m}^{3} / \mathrm{h}$. Assim fez-se a conversão dos resultados obtidos em (a) por meio da equação:

$$
(b)=[(a) / 0,00008988) / 8.760]
$$

Onde: 0,00008988 é a quantidade de hidrogênio por $\mathrm{m}^{3} \mathrm{em}$ toneladas 8.760 é o número de horas em um ano

(b) é a quantidade de $\mathrm{H}_{2}$ produzido $\mathrm{em}^{3}$.

Os dados para as diferentes regiões brasileiras exibidos nas TAB 40 a 44 são correspondentes aos resíduos agrícolas utilizados na gaseificação e produção de hidrogênio para a posterior geração de energia elétrica com a utilização de uma célula a combustível tendo os cálculos descritos acima como base. 
Tabela 40: Produção de hidrogênio na região Nordeste a partir da biomassa

\begin{tabular}{|c|c|c|c|c|}
\hline $\begin{array}{l}\text { Produção de } \\
\text { biomassa } \\
(\mathrm{t})^{\star} / \text { ano }\end{array}$ & $\begin{array}{l}\text { Resíduos } \\
\text { produzidos } \\
\text { em }(\mathrm{t})^{\star \star} / \text { ano }\end{array}$ & $\begin{array}{c}\text { \% média de } \mathrm{H}_{2} \\
\text { após } \\
\text { gaseificação } \\
\text { com } \\
\text { reforma }^{* * *}\end{array}$ & $\begin{array}{l}\text { Quantidade } \\
\text { de } \mathrm{H}_{2} \\
\text { produzido em } \\
\text { (t) /ano } \\
\text { (a) }\end{array}$ & $\begin{array}{l}\text { Quantidade de } \\
\mathrm{H}_{2} \text { produzido } \\
\text { em } \mathrm{m}^{3} \text { /ano } \\
\text { (b) }\end{array}$ \\
\hline 85.463 .079 & 40.940 .340 & 12,00 & 4.912 .841 & 6.239 .726 \\
\hline
\end{tabular}

Tabela 41: Produção de hidrogênio na região Norte a partir da biomassa.

\begin{tabular}{|c|c|c|c|c|}
\hline $\begin{array}{c}\text { Produção de } \\
\text { biomassa } \\
(\mathrm{t})^{\star} / \text { ano }\end{array}$ & $\begin{array}{c}\text { Resíduos } \\
\text { produzidos } \\
\text { em }(\mathrm{t})^{* *} / \mathrm{ano}\end{array}$ & $\begin{array}{c}\text { \% média de } \mathrm{H}_{2} \\
\text { após } \\
\text { gaseificação } \\
\text { com reforma** }\end{array}$ & $\begin{array}{c}\text { Quantidade de } \\
\mathrm{H}_{2} \text { produzido } \\
\text { em t/ano } \\
(\mathrm{a})\end{array}$ & $\begin{array}{c}\text { Quantidade } \\
\text { de } \mathrm{H}_{2} \\
\text { produzido em } \\
\mathrm{m}^{3} / \text { ano } \\
(\mathrm{b})\end{array}$ \\
\hline 30.857 .591 & 8.712 .655 & 12,00 & 1.045 .519 & 1.327 .898 \\
\hline
\end{tabular}

Tabela 42: Produção de hidrogênio na região Centro Oeste a partir da biomassa.

\begin{tabular}{|c|c|c|c|c|}
\hline $\begin{array}{c}\text { Produção de } \\
\text { biomassa } \\
(\mathrm{t})^{*} / \text { ano }\end{array}$ & $\begin{array}{c}\text { Resíduos } \\
\text { produzidos } \\
\text { em }(\mathrm{t})^{* *} / \text { ano }\end{array}$ & $\begin{array}{c}\text { \% média de } \mathrm{H}_{2} \\
\text { após } \\
\text { gaseificação } \\
\text { com reforma }\end{array}$ & $\begin{array}{c}\text { Quantidade de } \\
\mathrm{H}_{2} \text { produzido } \\
\text { em t/ano } \\
(\mathrm{a})\end{array}$ & $\begin{array}{c}\text { Quantidade } \\
\text { de } \mathrm{H}_{2} \\
\text { produzido em } \\
\mathrm{m}^{3} / \mathrm{ano} \\
(\mathrm{b})\end{array}$ \\
\hline 101.047 .292 & $\mathbf{8 1 . 1 8 2 . 0 4 9}$ & 12,00 & 9.741 .846 & 12.372 .974 \\
\hline
\end{tabular}


Tabela 43: Produção de energia na região Sudeste a partir da biomassa.

\begin{tabular}{|c|c|c|c|c|}
\hline $\begin{array}{c}\text { Produção de } \\
\text { biomassa } \\
(\mathrm{t})^{\star} / \text { ano }\end{array}$ & $\begin{array}{c}\text { Resíduos } \\
\text { produzidos } \\
\text { em }(\mathrm{t})^{\star *} / \mathrm{ano}\end{array}$ & $\begin{array}{c}\% \text { média de } \mathrm{H}_{2} \\
\text { após } \\
\text { gaseificação } \\
\text { com reforma }\end{array}$ & $\begin{array}{c}\text { Quantidade de } \\
\mathrm{H}_{2} \text { produzido } \\
\text { em t/ano } \\
(\mathrm{a})\end{array}$ & $\begin{array}{c}\text { Quantidade } \\
\text { de } \mathrm{H}_{2} \\
\text { produzido em } \\
\mathrm{m}^{3} / a n o \\
(\mathrm{~b})\end{array}$ \\
\hline 398.267 .140 & 131.019 .960 & 12,00 & 15.722 .395 & 19.968 .780 \\
\hline
\end{tabular}

Tabela 44: Produção de energia na região Sul a partir da biomassa.

\begin{tabular}{|c|c|c|c|c|}
\hline $\begin{array}{c}\text { Produção de } \\
\text { biomassa } \\
(\mathrm{t})^{*} / \text { ano }\end{array}$ & $\begin{array}{c}\text { Resíduos } \\
\text { produzidos } \\
\text { em }(\mathrm{t})^{* *} / \text { ano }\end{array}$ & $\begin{array}{c}\text { \% média de } \mathrm{H}_{2} \\
\text { após } \\
\text { gaseificação } \\
\text { com reforma*** }\end{array}$ & $\begin{array}{c}\text { Quantidade de } \\
\mathrm{H}_{2} \text { produzido } \\
\text { em t/ano } \\
(\mathrm{a})\end{array}$ & $\begin{array}{c}\text { Quantidade } \\
\text { de } \mathrm{H}_{2} \\
\text { produzido em } \\
\mathrm{m}^{3} / \text { ano } \\
(\mathrm{b})\end{array}$ \\
\hline 126.539 .012 & 102.924 .105 & 12,00 & 12.350 .893 & 15.686 .685
\end{tabular}




\subsection{Avaliação do Potencial da Energia Fotovoltaica para a produção de hidrogênio por região.}

Fez-se uma avaliação da produção de hidrogênio por meio do processo de eletrólise utilizando-se um sistema fotovoltaico.

É importante lembrar que a energia fotovoltaica pode ser utilizada diretamente na geração de energia elétrica, resultando em menor perda do que quando utilizada em processos secundários como a produção de hidrogênio por eletrólise.

O hidrogênio advindo do uso deste sistema poderá ser usado como acumulador de energia para utilização em células a combustível, quando não for possível aproveitar a luz solar diretamente (noite e dias muito nublados). Além disso, o excedente de energia gerada pode também ser estocado na forma de hidrogênio para uso posterior em momentos de maior consumo.

Para uma avaliação mais realista, mas conservadora, da capacidade de geração de energia elétrica a partir de painéis fotovoltaicos na produção de hidrogênio por meio da eletrólise, tomou-se como base o índice de expectativa de utilização de área territorial fornecido pelo "Solar Energy Tecnhnologies Program 2007-2011"115, procurando adaptá-lo à realidade brasileira ${ }^{121,122,123,124,125}$.

Este índice foi elaborado para os Estados Unidos da América e é de utilização de $0,5 \%$ do território para a instalação de painéis fotovoltaicos. Este valor foi ajustado tomando-se como base a proporcionalidade ao PIB brasileiro que é em média 7,5 vezes menor do que o PIB americano ${ }^{116}$. Chegou-se ao percentual de $0,07 \%$, de disponibilidade financeira de utilização do nosso território.

Para o cálculo da eficiência dos painéis fotovoltaicos, além da radiação global média do local é levado em conta pelos fabricantes de painéis um valor fixo de radiação ao nível do solo que é de $1 \mathrm{KWh} / \mathrm{m}^{231}$.

Para os cálculos da produção de hidrogênio foi utilizado o programa "PV Watts Version 1 Calculator"117, onde os principais parâmetros usados foram os seguintes: 
1- Identificação do local através da latitude e longitude.

2- Elevação do local em relação ao nível do mar.

3- As perdas para todo o sistema fotovoltaico como: inversores, transformadores, conexões e diodos. Essas perdas implicam na utilização de um fator de correção de 0,77 no cálculo da potência produzida.

4- Foi utilizado o sistema de painel fixo que é de menor rendimento, mas o de menor custo e mais fácil instalação, permitindo um cálculo conservador da quantidade de hidrogênio e energia capaz de ser produzida nesse sistema.

5- Inclinação correspondente à localização geográfica do local.

6- Dados das condições do tempo fornecidas pelo programa "SWERA" Solar and Wind Energy Resource Assessment ${ }^{118}$.

7- Condições padrão de teste para painéis fotovoltaicos que implicam no uso de uma radiação superficial de $1.000 \mathrm{~W} / \mathrm{m}^{2}$ a $25^{\circ} \mathrm{C}$.

8- Um rendimento teórico de $114 \mathrm{~W} / \mathrm{m}^{2}$, já que cada região apresenta um índice de radiação superficial diferente que varia geograficamente como sazonalmente e que vai afetar o cálculo do programa na determinação da energia gerada.

Para se obter a quantidade de hidrogênio total que poderá ser gerada com energia fotovoltaica para as diferentes regiões utilizaram-se os seguintes cálculos:

Área total da região em $\mathrm{km}^{2}$ (a) x porcentagem da área sugerida para a instalação de painéis fotovoltaicos.

$$
(b)=[(a) \times 0,07) / 100]
$$

Onde (b) é a área disponível sugerida.

Área disponível sugerida $\mathrm{em} \mathrm{km}^{2}$ (b) $\mathrm{x}$ quantidade de metros quadrados em $1 \mathrm{~km}^{2} \times 150 \mathrm{KWh} / \mathrm{m}^{2}$.ano, que é o rendimento médio do sistema fotovoltaico levando-se em consideração o índice de incidência de radiação nas regiões estudadas ${ }^{32,57}$. 


$$
(c)=[(b) \times 1.000 .000 \times 150]
$$

Onde (c) é a produção de energia fotovoltaica em $\mathrm{kWh} / \mathrm{m}^{2}$.ano com eficiência de 11,4\%.

O consumo do eletrolisador para a produção de $1 \mathrm{~m}^{3}$ de hidrogênio por hora foi fixado em $5,1 \mathrm{kWh}$ sendo um valor máximo em relação aos eletrolisadores disponíveis.

Para o resultado final da produção de hidrogênio pelo sistema fotovoltaico e eletrolisador foi feito o cálculo.

$$
(e)=[(c) /(d)]
$$

Onde: (e) é a produção de hidrogênio $\mathrm{em}^{3}$.

(c) é a produção de energia fotovoltaica em $\mathrm{kWh} / \mathrm{ano}$

(d) é o consumo do eletrolisador para produzir $1 \mathrm{~m}^{3}$ de hidrogênio

$\mathrm{Na}$ TAB 46 apresenta-se a quantidade de hidrogênio que pode ser produzida com a utilização do conjunto: painel fotovoltaico, eletrolisadores.

Tabela 46: Quantidade de hidrogênio e energia gerada com produção de energia

\begin{tabular}{|c|c|c|c|c|c|}
\hline Região & $\begin{array}{l}\text { Área total } \\
\text { da região } \\
\text { em Km² } \\
\text { (a) }\end{array}$ & $\begin{array}{c}\text { Área } \\
\text { disponível } \\
\text { com o índice } \\
\text { de } 0,07 \% \\
\text { em Km² } \\
\text { (b) }\end{array}$ & $\begin{array}{l}\text { Produção de } \\
\text { energia em } \\
\text { kWh/ano } \\
\text { (11,4\% de } \\
\text { eficiência) } \\
\text { (c) }\end{array}$ & $\begin{array}{l}\text { Consumo do } \\
\text { eletrolisador em } \\
\text { kWh } \\
\text { para produzir } \\
1 \mathrm{~m}^{3} \text { de } \mathrm{H}_{2} \\
\text { (d) }\end{array}$ & $\begin{array}{l}\text { Produção de } \mathrm{H}_{2} \\
\text { em m} \text { /ano } \\
\text { (e) }\end{array}$ \\
\hline Nordeste & 1.554 .543 & 1.088 & 163.200 .000 .000 & 5,1 & 32.000 .000 .000 \\
\hline Norte & 3.853 .023 & 2.697 & 404.550 .000 .000 & 5,1 & 79.323 .529 .411 \\
\hline $\begin{array}{l}\text { Centro } \\
\text { Oeste }\end{array}$ & 1.606 .371 & 1.124 & 168.600 .000 .000 & 5,1 & 33.058 .823 .529 \\
\hline Sudeste & 924.266 & 646 & 96.900 .000 .000 & 5,1 & 19.000 .000 .000 \\
\hline Sul & 577.214 & 404 & 60.600 .000 .000 & 5,1 & 11.882 .352 .941 \\
\hline
\end{tabular}
fotovoltaica nas Regiões do Brasil. 


\subsection{Avaliação do Potencial da Energia Eólica para a produção de hidrogênio por região.}

Segundo AMARANTE ${ }^{119}$ e GREINER ${ }^{120}$ é de fundamental importância lembrar que o potencial que será demonstrado neste trabalho é resultado de uma avaliação conservadora devido aos pontos citados abaixo:

1-Foram utilizadas velocidades do vento iguais ou superiores a $6 \mathrm{~m} . \mathrm{s}^{-1}$ quando atualmente estão sendo consideradas em outros países velocidades iguais ou inferiores a $4 \mathrm{~m} \cdot \mathrm{s}^{-1}$, o que aumentaria a capacidade de geração do parque eólico brasileiro

2-As turbinas eólicas utilizadas atualmente possuem maior potência e altura, $5 \mathrm{MW}$ e $75 \mathrm{~m}$ respectivamente, o que melhoraria substancialmente a capacidade de geração.

3-A densidade de turbinas por $\mathrm{Km}^{2}$ é cerca de $20 \%$ da utilizada internacionalmente.

4-Não foram consideradas áreas cobertas por água (lagos e mares), o que ocorre no exterior com a construção de grandes usinas eólicas offshore ${ }^{119,120}$.

Assim, pode-se afirmar que o potencial eólico estimado poderia ser bastante aumentado com a utilização de recursos mais modernos.

Para se obter a quantidade de hidrogênio total que poderia ser gerada com energia eólica para as diferentes regiões utilizaram-se os seguintes cálculos:

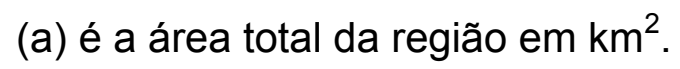

(b) é a área sugerida pelo Atlas do Potencial eólico brasileiro.

(c) é a Produção de energia segundo Atlas do Potencial eólico brasileiro.

(d) é o consumo do eletrolisador para produzir $1 \mathrm{~m}^{3}$ de hidrogênio.

(e) é a produção de hidrogênio em $\mathrm{m}^{3}$ e é obtido pela divisão (c/d).

$\mathrm{Na}$ TAB 47 apresenta-se a quantidade de hidrogênio que poderia ser gerada a partir da energia eólica utilizando-se o processo de eletrólise, com os dados especificados acima. 
Tabela 47: Quantidade de hidrogênio gerado com produção de energia eólica nas Regiões brasileiras

\begin{tabular}{|c|c|c|c|c|c|}
\hline Região & $\begin{array}{l}\text { Área total } \\
\text { da região } \\
\text { em } \mathrm{Km}^{2} \\
\text { (a) }\end{array}$ & $\begin{array}{c}\text { Área } \\
\text { disponível } \\
\text { em } \mathrm{Km}^{2} \\
\text { (b) }\end{array}$ & $\begin{array}{l}\text { Produção de } \\
\text { energia } \\
\text { em KWh/ano } \\
\text { (c) }\end{array}$ & $\begin{array}{c}\text { Consumo do } \\
\text { Eletrolisador } \\
\text { Para } \\
\text { produzir } 1 \mathrm{~m}^{3} \\
\text { de } \mathrm{H}_{2} \\
\text { em KWh } \\
\text { (d) }\end{array}$ & $\begin{array}{c}\text { Produção de } \mathrm{H}_{2} \\
\text { em } \mathrm{m}^{3} \text { /ano } \\
\text { (e) }\end{array}$ \\
\hline Nordeste & 1.554 .543 & 37.526 & 144.300 .000 .000 & 5,1 & 28.294 .117 .647 \\
\hline Norte & 3.853023 & 6.420 & 26.400 .000 .000 & 5,1 & 5.176 .470 .588 \\
\hline $\begin{array}{l}\text { Centro } \\
\text { Oeste }\end{array}$ & 1.606 .371 & 1.541 & 5.420 .000 .000 & 5,1 & 1.062 .745 .098 \\
\hline Sudeste & 924.266 & 14.869 & 54.930 .000 .000 & 5,1 & 10.770 .588 .235 \\
\hline Sul & 577.214 & 11.379 & 41.110 .000 .000 & 5,1 & 8.060 .784 .313 \\
\hline
\end{tabular}




\subsection{Cálculos para a produção de energia a partir do hidrogênio produzido pelos três sistemas avaliados.}

Os cálculos para se encontrar o potencial de geração de energia elétrica produzida pelos três sistemas avaliados neste trabalho podem ser vistos nas fórmulas abaixo:

(a) é a quantidade de hidrogênio em $\mathrm{m}^{3}$.

(b) é o consumo médio de hidrogênio em $\mathrm{m}^{3} / \mathrm{h}$ da célula a combustível para gerar $1 \mathrm{~kW} / \mathrm{h}$.

(c) é obtido pela divisão entre (a) e (b), sendo o resultado dividido inicialmente por 1 milhão (transformação de kW/h para GW/h) e novamente dividido por 2 (representa a eficiência elétrica média de uma célula a combustível que é de $50 \%$ ), tudo isso está representado na fórmula abaixo.

$(c)=((a) /(b) / 1.000 .000) / 2$

\subsubsection{Quantidade de energia gerada a partir da biomassa}

Na TAB 48 apresentam-se as quantidades de energia que poderiam ser geradas por região com o uso da gaseificação e reforma a vapor da biomassa e célula a combustível. 
Tabela 48: Quantidade de energia que pode ser gerada a partir da gaseificação de resíduos de biomassa em cada região do Brasil.

\begin{tabular}{|c|c|c|c|}
\hline Regiões & $\begin{array}{c}\text { Quantidade de } \mathrm{H}_{2} \\
\text { produzido em } \mathrm{m}^{3} / \mathrm{ano} \\
\text { (a) }\end{array}$ & $\begin{array}{c}\text { Consumo médio } \\
\text { em } \\
\text { m3 para geração } \\
\text { de } 1 \mathrm{kWh} \\
\text { em célula a } \\
\text { combustível (b) }\end{array}$ & $\begin{array}{c}\text { Energia total gerada } \\
\text { em GWh/ano } \\
(50 \% \text { de eficiência) } \\
\text { (c) }\end{array}$ \\
\hline Norte & 1.327 .898 & 0,63 & 1,1 \\
\hline Nordeste & 6.239 .726 & 0,63 & 5,0 \\
\hline $\begin{array}{c}\text { Centro } \\
\text { Oeste }\end{array}$ & 12.372 .974 & 0,63 & 9,8 \\
\hline Sudeste & 19.968 .780 & 0,63 & 15,9 \\
\hline Sul & 15.686 .685 & 0,63 & 12,5 \\
\hline
\end{tabular}

\subsubsection{Quantidade de energia gerada a partir da energia fotovoltaica}

$\mathrm{Na}$ TAB 49 apresentam-se as quantidades de energia que poderiam ser geradas por região com o uso do sistema fotovoltaico, eletrolisador, célula a combustível. 
Tabela 49: Quantidade de energia que pode ser gerada a partir da energia fotovoltaica com a utilização do hidrogênio em cada região do Brasil.

\begin{tabular}{|c|c|c|c|}
\hline Região & $\begin{array}{c}\text { Produção de } \mathrm{H}_{2} \text { em } \\
\mathrm{m}^{3} / \mathrm{ano} \\
(\mathrm{a})\end{array}$ & $\begin{array}{c}\text { Consumo médio } \\
\text { em } \\
\mathrm{m}^{3} \text { para geração } \\
\text { de 1kWh } \\
\text { em célula a } \\
\text { combustível }\end{array}$ & $\begin{array}{c}\text { Produção de energia } \\
\text { em GWh/ano } \\
(50 \% \text { de eficiência) } \\
\text { (c) }\end{array}$ \\
\hline Nordeste & 32.000 .000 .000 & 0,63 & 25.396 \\
\hline Norte & 79.323 .529 .411 & 0,63 & 62.955 \\
\hline $\begin{array}{c}\text { Centro } \\
\text { Oeste }\end{array}$ & 33.058 .823 .529 & 0,63 & 26.237 \\
\hline Sudeste & 19.000 .000 .000 & 0,63 & 15.079 \\
\hline Sul & 11.882 .352 .941 & 0,63 & 9.430 \\
\hline
\end{tabular}

\subsubsection{Quantidade de energia gerada a partir da energia eólica}

$\mathrm{Na}$ TAB 50 apresentam-se as quantidades de energia que poderiam ser geradas por região com o uso do sistema eólico, eletrolisador, célula a combustível. 
Tabela 50: Quantidade de energia elétrica que pode ser gerada a partir da energia eólica com a utilização do hidrogênio em cada região do Brasil.

\begin{tabular}{|c|c|c|c|}
\hline Região & $\begin{array}{l}\text { Produção de } \\
\qquad \mathrm{H}_{2} \\
\text { em mªno } \\
\text { (a) }\end{array}$ & $\begin{array}{l}\text { Consumo médio em } \\
\mathrm{m}^{3} \text { para geração de } 1 \mathrm{kWh} \\
\text { em célula a combustível } \\
\text { (b) }\end{array}$ & $\begin{array}{c}\text { Produção de } \\
\text { energia } \\
\text { em GWh/ano } \\
\text { (eficiência de } 50 \% \text { ) } \\
\text { (c) }\end{array}$ \\
\hline Nordeste & 28.294 .117 .647 & 0,63 & 22.456 \\
\hline Norte & 5.176 .470 .588 & 0,63 & 4.108 \\
\hline $\begin{array}{l}\text { Centro } \\
\text { Oeste }\end{array}$ & 1.062 .745 .098 & 0,63 & 843 \\
\hline Sudeste & 10.770 .588 .235 & 0,63 & 8.548 \\
\hline Sul & 8.060 .784 .313 & 0,63 & 6.397 \\
\hline
\end{tabular}

4.11 Avaliação do potencial total de produção de energia por tecnologia avaliada e por região.

Podemos verificar pela TAB 51 a quantidade de energia que pode ser gerada por meio de cada tecnologia estudada em cada região brasileira.

Tabela 51: Quantidade de energia gerada em GWh/ano por tecnologia avaliada.

\begin{tabular}{cclll}
\hline & Biomassa & Fotovoltaíca & Eólica & Total \\
\hline Região Nordeste & 5,0 & $25.396,0$ & $22.456,0$ & $47.857,0$ \\
Região Norte & 1,1 & $62.955,0$ & $4.108,0$ & $67.064,1$ \\
$\begin{array}{c}\text { Região Centro } \\
\text { Oeste }\end{array}$ & 9,8 & $26.237,0$ & 843,0 & $27.089,8$ \\
Região Sudeste & 15,9 & $15.079,0$ & 8.548 & $23.642,9$ \\
Região Sul & 12,5 & $9.430,0$ & 6.397 & $15.839,5$ \\
\hline Total & $\mathbf{4 4 , 3}$ & $\mathbf{1 3 9 . 0 9 8 , 0}$ & $\mathbf{4 2 . 3 5 2}$ & $181.493,3$ \\
\hline
\end{tabular}


Na TAB 51 pode-se notar que as tecnologias analisadas mostraram grandes diferenças entre si. Os maiores valores são encontrados nas simulações onde se utiliza a energia fotovoltaica. Isto é plenamente justificável levando-se em conta que este tipo de energia é grandemente privilegiada em um país tropical como o Brasil. Deve-se ressaltar que uma grande parte da biomassa que poderia ser utilizada para a geração de energia ainda não dispõe de índices de resíduos para a utilização nos cálculos.

\subsection{Avaliação do custo de produção de energia por tecnologia avaliada.}

Tomando-se como base um sistema de geração distribuída não ligado à rede, ou seja, onde nenhum equipamento receba aporte de energia que não seja gerada no próprio local e que não forneça energia para um sistema onde existam outras fontes geradoras e, além disso, onde a energia elétrica seja produzida por célula a combustível é possível ver na figura 28 o custo da produção de energia elétrica em reais por $\mathrm{MWh}^{128,129}$.

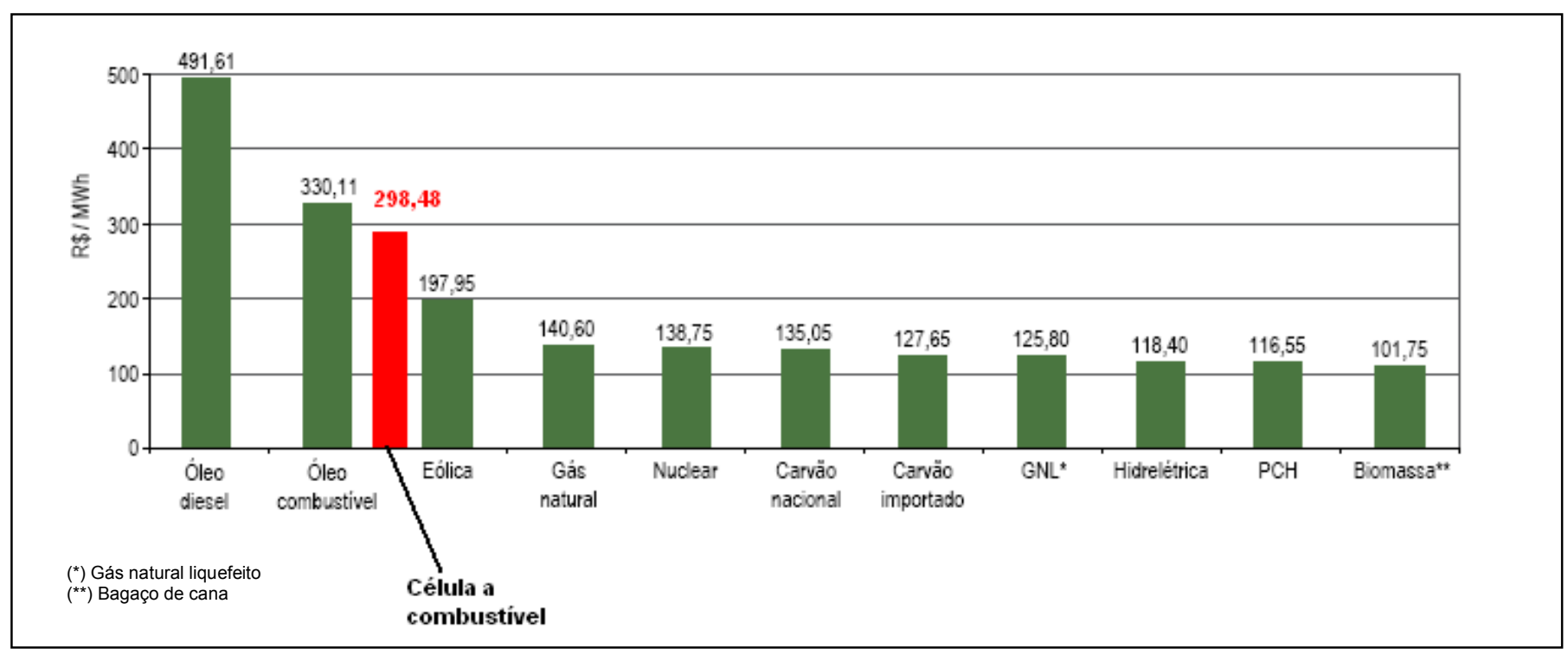

FIGURA 28: Comparação do custo de geração de energia elétrica por tipo de geração. 
É interessante notar que a energia gerada com célula a combustível fica abaixo da gerada por derivados do petróleo quando o preço no mercado desse combustível fica muito alto (por volta de $R \$ 100,00$ ), portanto os valores apresentados na FIG 28 são apenas indicativos de um momento do mercado de energia, mais especificamente o período 2007 a início de $2008^{128,129}$. 


\section{CONCLUSÕES, PERSPECTIVAS E RECOMENDAÇÕES.}

O Brasil apresenta uma diversidade no seu território e uma vocação para a produção agrícola que o colocam de maneira natural como um grande produtor de energia elétrica de baixo impacto ambiental.

Podemos ver, usando os dados obtidos nesse estudo que além de estar na vanguarda da produção de energia a partir da biomassa (álcool hidratado) o Brasil pode e deve aproveitar melhor a biomassa que é na sua grande maioria desperdiçada no campo, utilizando-a na produção de hidrogênio e, conseqüentemente, de eletricidade.

Quanto ao potencial fotovoltaico é possível ver que ele é imenso e subaproveitado, já que as condições geográficas são privilegiadas. Paralelamente ocorre a existência de regiões isoladas com acesso difícil como a Amazônia, por exemplo, onde a geração distribuída assume contornos de única alternativa factível de abastecer de energia elétrica de baixo impacto as populações isoladas, inclusive com uma grande disponibilidade de água para uso na eletrólise.

Em relação ao potencial eólico podemos notar que este assume uma posição intermediária em relação à capacidade de geração de energia elétrica no Brasil. Esse tipo de geração de energia renovável é o que mais tem crescido e conseqüentemente o que tem apresentado a maior queda de preço de geração de todas as renováveis disponíveis.

Todos os processos básicos de geração de energia analisados aqui tem como pilar a utilização da célula a combustível como alternativa de geração de energia no momento e hora em que ela é demandada. Tanto a biomassa através de sua gaseificação, como a fotovoltaica e a eólica, são processos que apresentam momentos de grande produção que na maior parte do tempo não são compatíveis com os momentos de demanda que a sociedade moderna exige. Assim sendo a célula a combustível vai ao encontro das necessidades dessa sociedade, utilizando o hidrogênio como vetor energético passível de estocagem e utilização no momento necessário.

As diferentes tecnologias de célula a combustível podem atender a diferentes necessidades de geração de energia, sendo importante lembrar que o 
enfoque desse trabalho é a célula estacionária que já esteja disponível em escala comercial, sendo possível, assim, uma análise mais apurada do seu desempenho.

A célula a combustível vai ao encontro das necessidades ambientais de geração energética de baixo impacto num cenário onde os combustíveis fósseis, especialmente o petróleo, vêm mostrando o lado sombrio da sua utilização no aumento vertiginoso da quantidade de gás carbônico na atmosfera com a acentuação do efeito estufa.

Faz-se necessário lembrar que avanços e desenvolvimentos devem ser obtidos ainda para que a célula a combustível possa assumir o importante papel que lhe cabe na geração de energia renovável.

Este trabalho procurou mostrar que não haverá solução para os atuais problemas ambientais sem o uso intensivo e simultâneo do conhecimento e da tecnologia. Em função disso, mesmo que atualmente, essas novas tecnologias para geração de energia apresentem custos mais elevados, chegará um momento em que valores maiores, tais como qualidade de vida e a própria sobrevivência de ecossistemas inteiros, deverão se sobrepor aos lucros e à visão estritamente econômica na implantação de qualquer projeto, principalmente aqueles que envolvem a geração de energia, visto que estes últimos são de fundamental importância para a estruturação e andamento dos demais.

O aproveitamento de todas as formas de geração de energia em um país das dimensões e localização privilegiadas como é o Brasil torna-se uma obrigação em função dos rumos ambiental e econômico que o desenvolvimento humano tem apresentado nas últimas décadas. Isto deve ser levado em conta especificamente na Região Norte, onde o consumo de combustíveis fósseis adquire uma importância maior, pois é nessa região onde muitos geradores movidos a óleo diesel são utilizados na produção de energia elétrica para pequenas comunidades ou mesmo cidades.

O aumento da população, a utilização acima da capacidade de suporte dos recursos naturais, o consumo desenfreado principalmente dos países desenvolvidos e a conseqüente necessidade de abastecimento energético para a sustentação desse consumo mostram de maneira clara que todo o recurso energético disponível deve ser utilizado desde que seja compatível com os preceitos de manutenção do meio ambiente. 
Muito ainda deve ser feito para que empreendimentos de geração de energia tenham como uma de suas diretrizes básicas o meio ambiente.

Para isso é de fundamental importância que inicialmente se adotem programas de políticas públicas para que projetos que visam á implantação de sistemas de geração renováveis não tenham sua seqüência interrompida a cada mudança de governo. Para isso o órgão governamental deve assumir o seu papel de fomentador tanto no aspecto do financiamento como do ferramental tecnológico produzido em suas universidades e centros de pesquisa visando o empresário que tenha interesse em projetos de geração.

Cabe também ao governo induzir as instituições de pesquisa para que possam desenvolver novas tecnologias compatíveis com as necessidades do país, elevando o nível de importância dos empreendimentos de geração de energia ambientalmente de baixo impacto para que o empresário veja nele uma maneira de ter o seu capital remunerado.

È possível verificar, nos resultados obtidos nesse trabalho, como a energia elétrica que poderia ser gerada a partir dos sistemas aqui propostos, cerca de 181,5 TWh/ano, tem um valor significativo se comparado com o total gerado por todo o sistema brasileiro /2007, que foi de 483,4 TWh/ano.

Assim medidas sociais como controle de natalidade, políticas de governo para a implantação de novos empreendimentos nas mais variadas áreas de infra-estrutura, incentivo constante na educação, pesquisa e desenvolvimento de novas tecnologias serão fundamentais para que se equacionem os grandes desafios na área de geração de energia de baixo impacto. 


\section{REFERÊNCIAS BIBLIOGRÁFICAS}

1 DOVI, V. G.; FRIEDLER, F.; HUISINGH, D. J.; KLEMES, J. R. Cleaner energy for sustainable future, Journal of Cleaner Production 17 (2009) 889-895

2 HIMRI, Y. A.; ARIF, S.; MALIK B.; STAMBOULI, A. B. C.; HIMRI, S. D.; DRAOUI, B. Review and use of the Algerian renewable energy for sustainable development Renewable and Sustainable Energy Reviews 13 (2009) 1584-1591

3 ENEX ENERGY. Geothermic energy in El Salvador. Disponível em: $<$ http://www.enex.is/?PagelD=176>

4 PLUNZ, R.; BARATLOO, M.; ORFF, K.; CONRAD, M. Geothermal Larderello: Tuscany, Italy. Princeton Architectural Press, 2006

5 ALLIS, R. G. Review of subsidence at Wairakei Field, New Zealand, Geothermics. 29 , 455-478. (2000)

6 BROWN, D. W.; DUCHANE, D. V. Scientific progress on the Fenton Hill HDR project since 1983. Geothermics 28 (4-5), 1999. 591-601

7 OMER, A. M.; Ground-source heat pumps systems and applications. Renewable and Sustainable Energy Reviews, 12, 2008. 344-371

8 PRODUCTION OF GEOTHERMAL ENERGY. Idaho National Laboratory INL. U.S. Disponível em:

$<$ https://inlportal.inl.gov/portal/server.pt?open=512\&objID=422\&\&PagelD $=345$ 3\&mode=2\&in_hi_userid=200\&cached=true>. Acesso em 26 Jan 2007.

9 YASUKAWA,K.; TAKASUGI, S. Present status of underground thermal utilization in Japan. Geothermics 32 (2003) 609-618

10 ATLAS DE ENERGIA ELÉTRICA DO BRASIL $3^{\text {a }}$ EDIÇÃO. Agência Nacional de ENERGIA Elétrica. 2. Ed. - Brasília : ANEEL, 2008. $236 \mathrm{p}$ : il.

11 Reportagem A Energia que vem dos oceanos. Disponível em $<$ http://opiniaoenoticia.com.br/vida/meio-ambiente/a-energia-que-vem-dosoceanos>. Acesso em 03 de Jun. 2009. 
12 GERAÇÃO DE ENERGIA ATRAVÉS DA MARÉ. Disponível em <http://www.dee.feis.unesp.br/usinaecoeletrica/maremotriz/nacional.htm>. Acesso em 03 de Jun. 2009.

13 KHAN, M.J.; BHUYAN, G.; IQBAL, M.T.; QUAICOE, J.E. Hydrokinetic energy conversion systems and assessment of horizontal and vertical axis turbines for river and tidal applications. A technology status review, Applied Energy, 2009; 1823-1835

14 FERREIRA, R.; M.; ESTEFEN, S. F. Alternative concept for tidal power plant with reservoir restrictions. Renewable Energy 34, 2009; 1151-1157

15 SOPIAN, K. IBRAHIM M. Z. DAUD W. R. W. OTHMAN M. Y. YATIM B. AMIN $\mathrm{N}$. Performance of a PV-wind hybrid system for hydrogen production. Renewable Energy 34, 2009; 1973-1978.

16 ZINI, G. TARTARINI, P. Hybrid systems for solar hydrogen: A selection of case-studies. Applied Thermal Engineering 29, 2009; 2585-2595

17 AMARANTE O. A. C; BROWER M; ZACK J; LEITE S. A. Atlas do potencial eólico Brasileiro - Brasília, 2001; CRESESB.

18 DANISH WIND INDUSTRY ASSOCIATION. Wind Energy Reference Manual. Disponível em: < http://www.windpower.org/en/stat/units.htm>. Acesso em 02 Abr. 2006.

19 HANSEN M. O.L. Aerodynamics of Wind Turbines, Rotors, Loads and Structure. James \& James Ltd., London 2000.

20 WIND AND HYDROPOWER TECHNOLOGIES PROGRAM. U.S. Department of Energy. Disponível em:

<http://www1.eere.energy.gov/windandhydro/wind how.html\#inside>. Acesso em 10 Jan. 2008.

21 TAVNER, P. Wind power as a clean-energy contributor.Energy Policy, Volume 36, December 2008, 4397-4400

22 MONTES, G. M.; MARTÍN , E. P. Profitability of wind energy: Short-term risk factors and possible improvements. Renewable and Sustainable Energy Reviews, V 11, n 9, p. 2191-2200, 2007. 
23 SCHENK, N. J.; MOLL, H. C.; POTTING, J.; BENDERS, R. M. J. Wind energy, electricity, and hydrogen in the Netherlands. Energy, $\vee 32$, n. 10, , p. $1960-1971,2007$

24 MIRZA, U. K.; AHMAD, N.; MAJEED, T.; HARIJAN, K. Wind energy development in Pakistan. Renewable and Sustainable Energy Reviews, V 11, n. 9, p. 2179-2190, 2007.

25 MARKEVIČIUS, A.; KATINAS, V.; MARČIUKAITIS, M. Wind energy development policy and prospects in Lithuania. Energy Policy, V 35, n. 10, p.4893-4901, 2007

26 OSTERGAARD, P. A. Geographic aggregation and wind power output variance in Denmark. Energy, V 33, n. 9, p.1453-1460, 2008

27 ALBOYACI, B.; DURSUN, B. Electricity restructuring in Turkey and the share of wind energy production. Renewable Energy, v 33, n. 11, p.24992505, 2008.

28 DENIS, G. S.; PARKER, P. Community energy planning in Canada: The role of renewable energy. Renewable and Sustainable Energy Reviews, In Press, Corrected Proof. Disponível em:

<http://www.sciencedirect.com/science>. Acesso Nov. 2008

29 NEMA, P.; NEMA, R.K.; RANGNEKAR, J. A current and future state of art development of hybrid energy system using wind and PV-solar: A review. Renewable and Sustainable Energy Reviews, In Press, Corrected Proof. Disponível em: <http://www.sciencedirect.com/science>. Acesso Dez. 2008.

30 DUTRA, R.; SZKLO, A. Assessing long-term incentive programs for implementing wind power in Brazil using GIS rule-based methods. Renewable Energy, v. 33, n. 12, p. 2507-2515, 2008.

31 MARKWART T, CASTANER L. Practical handbook of photovoltaic. Oxford: Elsevier; 2003.

32 GUEYMARD, C. A. The sun's total and spectral irradiance for solar energy applications and solar radiation models. Solar Energy 76 (2004) 423-453

33 STUHLMANN, R.; RIELAND, M.; RASCHKE, E. An improvement of the IGMK model to derive total and diffuse solar radiation at the surface from satellitedata. J. Applied Meteorology, 29(7): 586-603, 1990. 
34 BALANÇO ENERGÉTICO NACIONAL 2008. ANO BASE 2007. Empresa de Pesquisa Energética. Rio de Janeiro: EPE, 2008. 244 p. il.

35 STUHLMANN, R.; RIELAND, M.; RASCHKE, E. An improvement of the IGMK model to derive total and diffuse solar radiation at the surface from satellitedata. J. Applied Meteorology, 29(7): 586-603, 1990.

36 PEREIRA, E. B.; MARTINS, F. R.; ABREU, S. L.; RÜTHER, R. Atlas Brasileiro de Energia Solar. São José dos campos: INPE, 2006

37 DAYLIGHT AND SOLAR RADIATION. European Database 2005. Disponível em <http://www.satel-light.com/>. Acesso em 08 Nov. 2005.

38 CRESESB. Tutorial de Energia Solar - Princípios e Aplicações, 2002. Centro de Referência para energia solar e eólica Sérgio de Salvo Brito. Disponível em <http://www.cresesb.cepel.br/index.php?link=http\%3A//www.cresesb.cepel.br/ potencial_solar.htm>. Acesso em 22 Fev. 2006

39 MERCALDO, L. V.; ADDONIZIO, M. L. ; NOCE, M. D. ; VENERI, P. D. ; SCOGNAMIGLIO, A.; PRIVATO, C. Thin film silicon photovoltaics: Architectural perspectives and technological issues. Applied Energy, $\mathrm{n}$. 86, p. 1836-1844, 2009.

40 Filizola, N.; Guyot, J. L.; Molinier, M.; Oliveira, G.; Freitas, M. A. V. Caracterização Hidrológica da Bacia Amazônica. Em Amazônia - Uma Perspectiva Interdisciplinar, Rivas, C. E. A \& Freitas (org), Ed. Universidade do Amazonas, Manaus, 2002.

41 BARRETO, L.; MAKIHIRAA, A.; RIAHI, K. The hydrogen economy in the 21st century: a sustainable development scenario. International Journal of Hydrogen Energy v.28, 267-284, 2003.

42 JOHNSTON, M. B.; MAYO, C.; KHARE, A. Hydrogen: the energy source for the 21st century. Technovation v. 25, p. 569-585, 2005.

43 GOLTSOVA, V. A.; VEZIROGLUB, T.N.; GOLTSOVA, L.F. Hydrogen civilization of the future-A new conception of the IAHE. International Journal of Hydrogen Energy n. 31, p.153-159, 2006.

44 MCDOWALL, W.; EAMES, M. Forecasts, scenarios, visions, backcasts and roadmaps to the hydrogen economy: A review of the hydrogen futures literature. Energy Policy n.34, p. 1236-1250, 2006. 
45 KÖNNÖLÄ, T.; GREGORY C. UNRUH B.; HERMOSILLA, J. C. Toward prospective voluntary agreements: reflections from a hydrogen foresight project. Journal of Cleaner Production n.15, p. 259-265, 2005.

46 MIDILLIA, A.; DINCERB, I. Key strategies of hydrogen energy s stems for sustainability. International Journal of Hydrogen Energy n.32, p. 511-524, 2007.

47 RUIJVENA,B.; DETLEF P.;VUURENB, V.; VRIES, B. The potential role of hydrogen in energy systems with and without climate policy. International Journal of Hydrogen Energy, n.32, p.1655-1672, 2007.

48 AGNOLUCCI, P.; MCDOWALL, W. Technological change in niches: Auxiliary Power Units and the hydrogen economy. Technological Forecasting \& Social Change n.74, p.1394-1410, 2007.

49 MARBÁN, G.; VALDÉS-SOLÍS, T. Towards the hydrogen economy?. International Journal of Hydrogen Energy n.32, p. 1625-1637, 2007.

50 MCDOWALL, W.; EAMES, M. Towards a sustainable hydrogen economy: A multi-criteria sustainability appraisal of competing hydrogen futures. International Journal of Hydrogen Energy n.32, p. 4611-4626, 2007.

51 BLANCHETTE, S. JR. A hydrogen economy and its impact on the world as we know it. Energy Policy n. 36, p. 522-530, 2008.

52 EDWARDS, P.P. A.; KUZNETSOV, V.L.; DAVID, W.I.F.; BRANDON, N.P. Hydrogen and fuel cells: Towards a-sustainable energy future. Energy Policy, n.36, p. 4356-4362, 2008.

53 UTC FUEL CELLS. About Fuel Cells. Disponível em: $<$ http://www.utcfuelcells.com/fuelcells/how fl.shtml>. Acesso em 18 Mai 2004

54 THE CALIFORNIA HYDROGEN BUSINESS COUNCIL. Fuel Cell handbook, 1998. Disponível em:<URL:http://www.ch2bc.org/FCHandbook/TechOver1 1FCDesc.htm>. Acesso em 25 Fev. 2006.

55 NOGUEIRA S. O PODER DO HIDROGÊNIO. Folha de São Paulo, São Paulo, 2000 dez 10; Cad. Mais Ciência.

56 UNITED NATIONS DEVELOPMENT PROGRAMME. Environmental strategy for energy: hydrogen fuel cell buses for brazil. Report. São Paulo; 1999.(Final report on phase I). 
57 HYDROGEN, FUEL CELLS \& INFRASTRUCTURE TECHNOLOGIES PROGRAM. Types of fuel cells. U.S. Department of Energy. Disponível em < http://www1.eere.energy.gov/hydrogenandfuelcells/fuelcells/fc types.html>. Acesso em 08 Jun. 2006.

58 GONZALEZ E. Células a combustível de eletrólito polimérico sólido. Apresentada ao Workshop Internacional de Células a Combustível no Centro de Convenção da UNICAMP; 2002 out 31, Campinas. Disponível em < http://www.ifi.unicamp.br/ceneh>. Acesso em 12 Ago. 2005

59 CONTADINI F. P \& D e o estado da arte de células a combustível na América do Norte. Apresentada ao Workshop Internacional de Células a Combustível no Centro de Convenção da UNICAMP; 2002 out 31, Campinas. Disponível em < http://www.ifi.unicamp.br/ceneh>. Acesso em 02 Mai 2005.

60 NOTA TÉCNICA. HOTMODULE FUEL CELLS: THE NATURAL CHOICE FOR BIOGAS AND SEWAGE GAS OPERATION. MTU Fuel Cell, 2008. Disponível em <http://www.mtu-online.com/mtuonsiteenergy/press/press archive/details/news>. Acesso em 06 Dez. 2008.

61 CENTRO DE GESTÃO E ESTUDOS ESTRATÉGICOS. SECRETARIA TÉCNICA DO FUNDO SETORIAL DE ENERGIA. Programa brasileiro de células a combustível. Rio de Janeiro; 2002. (Proposta para o Programa coordenada pelo CGEE).

62 HYDROGEN AND FUEL CELLS. Alternative Energy Institute, Inc. Disponível em: < http://www.altenergy.org/renewables/hydrogen power.html>. Acesso em 05 de Mai. 2005

63 LEE, D. H.; HSU, S. S. ; TSO, C. T. ; SU, A. ; LEE, D. J. An economy-wide analysis of hydrogen economy in Taiwan. Renewable Energy n.34, p.1947-1954, 2009

64 IVY, J. Summary of Electrolytic Hydrogen Production, Milestone Completion Report, September 2004 • NREL/MP-560-36734 September 2004 NREL

65 SCHUCKERT, M. "CUTE - A major step towards cleaner urban transport" apresentado no: Hydrogen and Fuel Cell Expert Workshop, IEA, Paris, 28 Jun 2005

66 PROSPECTS FOR HYDROGEN AND FUELL CELLS. INTERNATIONAL ENERGY AGENGY (IEA). Head of Publications Service. Paris, 2005. 
67 PRINCE-RICHARD, S. "A Techno-Economic Analysis of Decentralized Electrolytic Hydrogen Production for Fuel Cell Vehicles", Master Thesis, University of Victoria, Canada, 2004. Disponível em:

$<w w w . i e s v i c . u v i c . c a / l i b r a r y / p u b l i c a t i o n s / D i s s e r t a t i o n-S P R i c h a r d . p d f>$. Acesso em 04 Abri. 2007.

68 ENERGY FROM BIOMASS. Biomass gasification and fuel cell coupling via high temperature gás clean-up for decentralized eletricity generation with improved efficiency. European Project ENK-CT200000314, 2000. Disponível em: <http://dsiaq1.ing.univaq.it/ bio_en/eu2000.html.>. Acesso 07 Ago. 2007.

69 HARTSTEIN, ARTHUR. Hydrogen Production from Natural Gas. The Hydrogen Coordination Meeting. U.S. Department of Energy Office of Fossil Energy. June 2, 2003. Disponível em:

<http://www1.eere.energy.gov/hydrogenandfuelcells/pdfs/hartstein_fe_natural _gas.pdf>. Acesso em 10 Ago. 2005

70 GASIFICATION WORLD DATABASE. Current Industry Status. U.S. Department of Energy Office of Fossil Energy National Energy Technology laboratory, 2007. Disponível em:

<http://www.netl.doe.gov/technologies/coalpower/gasification/database/Gasific ation2007_web.pdf>. Acesso em 06 Jan. 2008

71 ABE, J. AT ALL. Toward a Renewable Power Supply: The use of Bio-based Fuels in Stationary Fuel Cells. XENERGY, Burrlington, MA, 2002.

72 S. DASAPPA AT ALL. Biomass gasification technology - a route to meet energy needs. Department of Aerospace Engineering. Centre for Susteinable Techonologies. Indian Institute of Science. India, 2005.

73 CHANG J, LEE K, LIN P. Biohidrogen production with fixed-bed bioreactors. International journal of Hydrogen Energy; 2002; 26: 1167-74

74 USHIMA, A. H. "Aspectos Tecnológicos de Gaseificadores e Sistema de Limpeza de Gases". CENBIO, 2002.

75 REED, T. B.; GRABOSKI, M. S.; LEVIE, B. Fundamentals, development \& scale - up of the air-oxygen stratified downdraft gasifier. Biomass Energy Foundation Press, 1994.

76 MUKUNDA, H. S. AT ALL. Gasifiers and combustors for biomass technology and field studies. Department of Aerospace Engineering, Indian Institute of Science, Bangalore, India. Energy for Sustainable Development I Volume I No. 3 I September 1994. 
77 BOWEN D. A.; LAU F., ZABRANSKY R.; REMICK R.; SLIMANE R.; DOONG $S$. Techno-Economic Analysis of Hydrogen Production by Gasification of Biomass Hydrogen, Fuel Cells, and Infrastructure Technologies. FY 2003 Progress Report

<http://www1.eere.energy.gov/hydrogenandfuelcells/pdfs/iib5_bowen.pdf Mar> Acesso em 04 Fev. 2007.

$78 \mathrm{G}$. IAQUANIELLO, A. MANGIAPANE. Integration of biomass gasification with MCFC. International Journal of Hydrogen Energy 31, 2006, p 399-404

79 TURN S.; KINOSHITA C.; ZHANG Z.; ISHIMURA D.; ZHOU J.; an Experimental Investigation of Hydrogen Production From Biomass Gasification. International journal of Hydrogen Energy; 1998; 23: 641-648

80 FLORIN N. H. ; HARRIS A. T. Hydrogen production from biomass coupled with carbon dioxide capture: The implications of thermodynamic equilibrium. International Journal of Hydrogen Energy, 2007.

81 LISS, E. W. AT ALL. Development of a natural gas to hydrogen fuel station. Proceedings of the 2002 U.S. DOE Hydrogen Program Review NREL. Disponível em:

<http://www1.eere.energy.gov/hydrogenandfuelcells/pdfs/32405a38.pdf.> Acesso em 10 de Abr. 2005

82 GAO, N. LI, A., QUAN, C. A novel reforming method for hydrogen production from biomass steam gasification. Bioresource Technology 100 (2009) 4271-4277

83 SEITARIDES, Th. ; ATHANASIOU C. ; ZABANIOTOU, A. Modular biomass gasification-based solid oxide fuel cells (SOFC) for sustainable development. Renewable \& Sustainable Energy Reviews. (2007)

84 ATHANASIOU C. ; COUTELIERES F. ; VAKOUFTSI E. ; SKOULOU V. ; ANTONAKOU E. ; MARNELLOS G. ; ZABANIOTOU A. From biomass to eletricity through integrated gasification/SOFC system-optimization and energy balance. International journal of Hydrogen Energy 32 (2007) 337-342

85 AHMED, I. ; GUPTA A.K. Syngas yield during pyrolysis and steam gasification of paper. Applied Energy 86 (2009) 1813-1821

86 SPAGNOLO, D.A.; CORNETT, L. J.; CHUANG, K. T. Direct Electro-Steam Reforming: A Novel Catalytic Approach. Journal Hydrogen Energy; 1992. 17(11):pp. 839-846. 
87 MAHISHI, M. R. ; GOSWAMI, D. Y. An experimental study of hydrogen production by gasification of biomass in the presence of a $\mathrm{CO}_{2}$ sorbent. International Journal of Hydrogen Energy (2007).

88 TECHNOLOGIES FOR BIOMASS UTILIZATION. Combustion Gasification \& Propulsion Lab, Dapartment of Aerospace Engineering of Indian Institute of Science Bangalore. India, 2005

89 KOUTROULI, E. C.; KALFAS, H. ; GAVALA, H. N. ; SKIADAS, I. V. ; STAMATELATOU, K. ; LYBERATOS L. Hydrogen and methane production through two-stage mesophilic anaerobic digestion of olive pulp. Bioresource Technology n. 100, p. 3718-3723, 2007.

90 GHIRARDI M. L. KOSOUROV S. SEIBERT M. CYCLIC PHOTOBIOLOGICAL ALGAL H2-PRODUCTION. National Renewable Energy Laboratory, 2001.

91 ATLAS DE ENERGIA ELÉTRICA DO BRASIL $3^{a}$ EDIÇÃO. Agência Nacional de energia Elétrica. 2. Ed. - Brasília : ANEEL, 2008. 236 p : il.

92 PESQUISA NACIONAL POR AMOSTRA DE DOMICÍLIOS 2007. Instituto Brasileiro de geografia e estatística IBGE. AV. FRANKLIN ROOSEVELT, 166 - CENTRO - 20021-120 - RIO DE JANEIRO, RJ - BRASIL.

93 ALAN C. BRENT AND WIKUS, J. KRUGER, L. Systems analysis and the sustainable transfer of renewable energy technologies. A focus on remote areas of Africa, Renewable Energy, 34, 1774-1781, 2009.

94 JUDITH A. CHERNI AND YOHAN H. Energy and policy providing for sustainable rural livelihoods in remote locations - The case of Cuba Geoforum (2009).

95 BUCHHOLZ, T.; RAMETSTEINER, E.; TIMOTHY, A.; LUZADIS, V. V. A. Multi Criteria Analysis for bioenergy systems assessments. Energy Policy, n.37, p. 484-495, 2009.

96 TURNER, K. Negative rebound and disinvestment effects in response to an improvement in energy efficiency in the UK economy. Energy Economics, "in press".

97 BECCALI, M.; COLUMBA, P.; D'ALBERT, V.; FRANZITTA, V. Assessment of bioenergy potential in Sicily: AGIS-based support methodology. Biomass and Bioenergy , n. 33 p. 79-87, 2009. 
98 BJORN, H.; HANS, B. I.; WOLFGANG, S. O. Transport: Investment planning in energy supply systems with multiple energy carriers. Energy n. 32 p. 1676-1689, 2007.

99 CHAVANNE, X.; FRANGI, J. P. De la de'termination du rendement des filières énergétiques, C. R. Geoscience n. 339, p.519-535, 2007

100 JUDITH, A.; CHERNI, I. D.; HENAOC F.; JARAMILLO, P.; SMITH, R.; FONT, R. O. Energy supply for sustainable rural live,lihoods. A multi-criteria decision-support system, Energy Policy, n.35, p. 1493-1504, 2007.

101 JUDITH A.; PRESTON, F. Rural electrification under liberal reforms: the case of Peru. Journal of Cleaner Production n.15 p.143-152, 2007.

102 BRANDEN, B.; PAMELA, J.; FRANK, G. Public understanding of environmental impacts of electricity deregulation. Energy Policy n.34, p. 1332-1343, 2007.

103 BELLER, M.; DOERNBERG, A.; HERMELEE, A.; KENNETH,C. H. Impacts of new energy technologies as measured against reference energy systems. Energy, Volume 4, n. 5, p. 891-909, 1997.

104 PROTOCOLO DE KYOTO. Convenção sobre mudança do clima. Tradução conjunta Ministério da Ciência e Tecnologia - MCT e Ministério das Relações Exteriores. 2008.

105 BATTAGLINI, A..; LILLIESTAM, J.; PATT, H. A. Development of Super Smart Grids for a more efficient utilization of electricity from renewable sources . Journal of Cleaner Production, 2009, p. 17:1-8.

$106 \mathrm{KANNICHE}, \mathrm{M}$.; BOUALLOU C. $\mathrm{CO}_{2}$ capture study in advanced integrated gasification combined cycle. Applied Thermal Engineering, 2007, n.27, p. 2693-270,

107 SIKOS, L.; RAMS, K. J. Contribution to efficient waste minimization and management. Journal of Cleaner Production 2009; p. 17:932-9.

108 LINARDI, M. Células a combustível SOFC e PEMFC de baixa potência para geração de energia elétrica distribuída. Apresentado no: WORKSHOP INTERNACIONAL DE CÉLULAS A COMBUSTÍVEL NO CENTRO DE CONVENÇÃO DA UNICAMP; 2002 out 31, Campinas. Disponível em: <http://www.ifi.unicamp.br/ceneh>. Acesso em 18 Nov. 2004 
109 LISS, E. W. AT ALL. Development of a natural gas to hydrogen fuel station. Proceedings of the 2002 U.S. DOE Hydrogen Program Review NREL. Disponível em:

<http://www1.eere.energy.gov/hydrogenandfuelcells/pdfs/32405a38.pdf.> Acesso em 10 de Abr. 2005

110 SOUZA N. M, SAMUEL AT ALL. Potencial de energia primária de resíduos vegetais no Paraná - $4^{\circ}$ Encontro de Energia no Meio Rural, 2001.

111 CENTRO DE GESTÃO E ESTUDOS ESTRATÉGICOS CTENERG. Geração de energia a partir de biomassa no Brasil: situação atual, oportunidades e desenvolvimento. Cgee, 2001.

112 SANTOS, E. C. S.; SOUZA, R. C. R.; SEYE, O.; LAU, J.; FREITAS, K. T. Aproveitamento da casca do cupuaçuzeiro para a produção de energia. Centro de Desenvolvimento Energético Amazônico-CDEAM, Manaus, 2004.

113 SISTEMA IBGE DE RECUPERAÇÃO AUTOMÁTICA - SIDRA. Instituto Brasileiro de Geografia e Estatística IBGE. Disponível em $<$ http://www.sidra.ibge.gov.br/bda/popul/default.asp?t=6\&z=t\&o=23\&u1=1\&u2 =1\&u3=1\&u4=1\&u5=1\&u6=6>. Acesso em 21 Abr. 2008.

114 INSTITUTO BRASILEIRO DE GEOGRAFIA E ESTATÍSTICA. IBGE Mapas. Disponível em:

<http://www.ibge.gov.br/7a12/mapas/default.php?id_tema_menu=13> . Acesso em 15 de Out. 2008.

115 SOLAR ENERGY TECHNOLOGIES PROGRAM MULTI - YEAR PROGRAM PLAN 2007- 2011. Energy Efficiency and Renewable Energy. U.S. Department of Energy, 2006. 117p : il

116 TECHNICAL AND ECONOMIC ASSESSMENT OF OFF-GRID, MINI-GRID AND GRID ELECTRIFICATION TECHNOLOGIES. Energy, Transport and water Department the World Bank Group. Washington D.C. 2007.

117 NREL NATIONAL RENEWABLE ENERGY LABORATORY. PV Watts version 1 calculator. Disponível em

<http://www.NREL.gov/rredc/pvwatts/version1.html>. Acesso em 10 Jan. 2007.

118 SOLAR AND WIND ENERGY RESOURCE ASSESSMENT (SWERA). GEF, UNEP/DTIE, DLR - Institute of technical thermodynamics, UNEP/GEF Coordination Office in Nairobi, NASA, USA, NREL, USA, 2008. Disponível em <http://swera.unep.net/index.php?id=7>. Acesso em 11 Abr.2008. 
119 AMARANTE O. A. C; BROWER M; ZACK J; LEITE S. A. Atlas do potencial eólico Brasileiro - Brasília, 2001; CRESESB.

120 GREINER, C. J.; KORPAS, M.; HOLEN A. T. A Norwegian case study on the production of hydrogen from wind power. International Journal of Hydrogen Energy. N. 32, p. 1500-1507, 2007.

121 VIDUEIRA. J. M. ; CONTRERAS A. ; VEZIROGLU T.N. PV autonomus installation to produce hydrogen via electrolysis, and its use in FC buses. International Journal of Hydrogen Energy 28 (2003) 927-937.

122 ELAM, C. Grid-Based Renewable Electricity and Hydrogen Integration, October 2004. NREL 2004.

123 J.I. LEVENE. An Analysis of Hidrogen production from renewable electricity Sources. National Renewable Energy Laboratory. Florida 2005

124 RÜTHER R. Panorama Atual da Utilização da Energia Solar Fotovoltaica e OTrabalho do Labsolar nesta Área. LABSOLAR - Laboratório de Energia Solar Departamento de Engenharia Mecânica Universidade Federal de Santa Catarina - UFSC, 2002. 19p : II

125 DAYLIGHT AND SOLAR RADIATION. European Database 2005. Disponível em <http://www.satel-light.com/>. Acesso em 08 Nov. 2005.

$126 \mathrm{KHAN}$, M.J. ; IQBAL M.T. Analysis of a small wind-hydrogen stand-alone hybrid energy system. Applied Energy. Applied Energy 86 (2009) 2429-2442

127 ROSEN, M. A. Thermodynamic Comparison of Hydrogen Production Processes. International Journal Hydrogen Energy 21 (1996) 349 -365.

128 BOCKRIS, J. O. M. ; VEZIROGLU T. N. Estimates of the price of hydrogen as a médium for Wind and solar sources. International Journal of Hydrogen Energy 32 (2007) $1605-1610$.

129 RENEWABLES IN GLOBAL ENERGY SUPPLY. International Energy Agency OECD, 2007. 